Chicago-Kent College of Law

Scholarly Commons @ IIT Chicago-Kent College of Law

All Faculty Scholarship

Faculty Scholarship

March 2002

\title{
Extraterritoriality and Political Heterogeneity in American Federalism
}

Mark D. Rosen

IIT Chicago-Kent College of Law, mrosen1@kentlaw.iit.edu

Follow this and additional works at: https://scholarship.kentlaw.iit.edu/fac_schol

Part of the Constitutional Law Commons

\section{Recommended Citation}

Mark D. Rosen, Extraterritoriality and Political Heterogeneity in American Federalism, 150 U. Pa. L. Rev. 856 (2002).

Available at: https://scholarship.kentlaw.iit.edu/fac_schol/519

This Article is brought to you for free and open access by the Faculty Scholarship at Scholarly Commons @ IIT Chicago-Kent College of Law. It has been accepted for inclusion in All Faculty Scholarship by an authorized administrator of Scholarly Commons @ IIT Chicago-Kent College of Law. For more information, please contact jwenger@kentlaw.iit.edu, ebarney@kentlaw.iit.edu. 


\section{EXTRATERRITORIALITY AND POLITICAL HETEROGENEITY IN AMERICAN FEDERALISM}

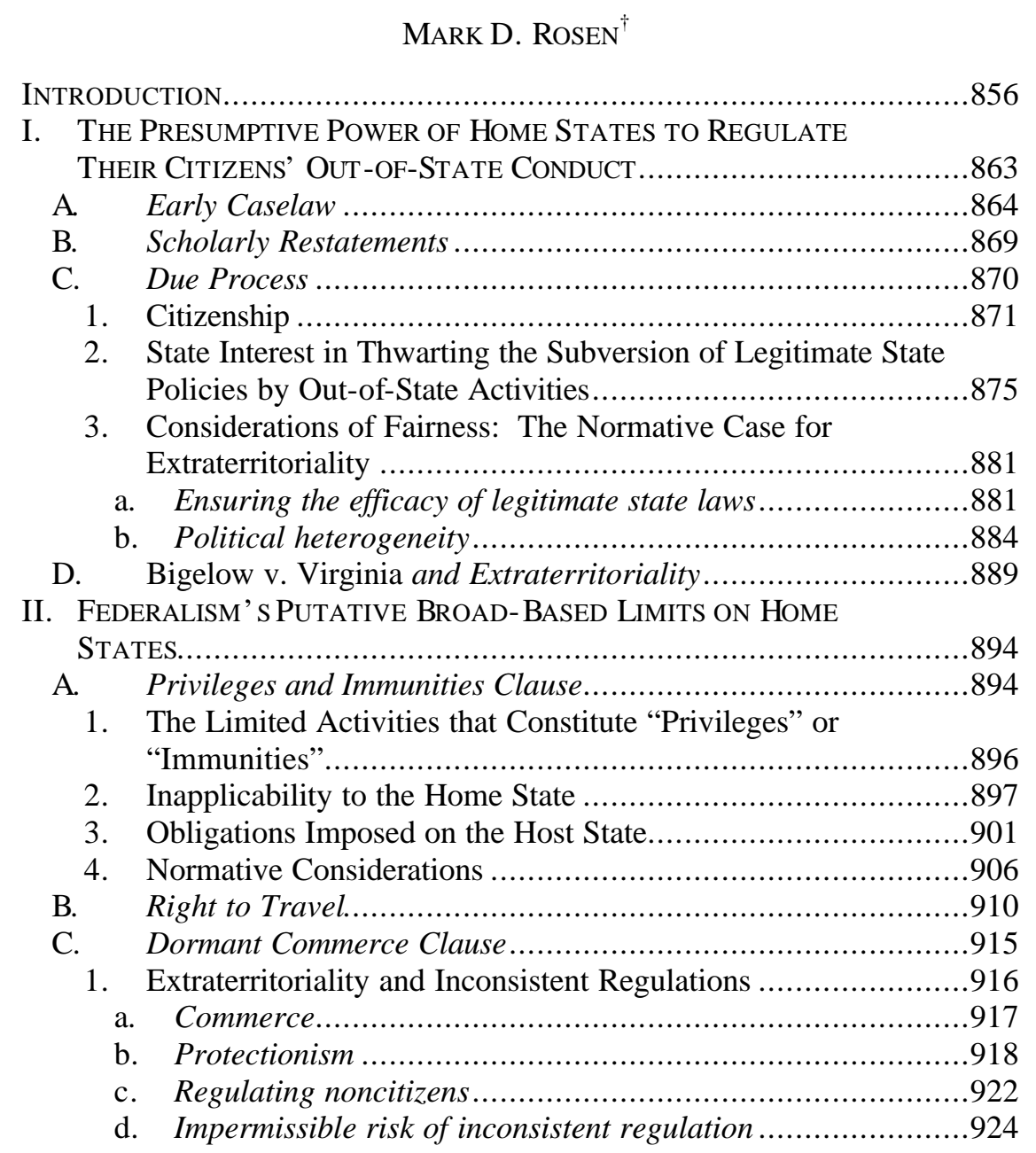

2. The Example of Dean Foods v. Brancel .............................926

\footnotetext{
${ }^{\dagger}$ Assistant Professor, Chicago-Kent College of Law, Illinois Institute of Technology. I would like to thank David Currie for the crucial input he provided at an early stage of this project and Graeme Dinwoodie, Hal Krent, Margaret Stewart, and Spencer Weber Waller for outstanding comments. I also benefited from comments I received at a faculty workshop at the Marquette Univ ersity School of Law and from participants at the 2001 Law, Culture and Humanities Conference in Austin, Texas. This project was supported by a grant from the Marshall Ewell Research Fund.
} 
D. Structural Constitutional Considerations

1. Exclusive Territory-Based Jurisdiction in Respect of

Policies About Which There Are Sharp Moral

Disagreements Among States

a. The problematics of a single "connecting factor"................930

b. The problematics of categorically subordinating the Home

State's interests.

2. Exclusive State Sovereignty over Conduct Within a

State's Borders

III. OUR SYSTEM OF CONCURRENT JuRISDICTION ..............................9940

A. The Fact of Concurrent Regulatory Jurisdiction ......................941

B. Concurrent Jurisdiction and Interstate Conflict-A Prologue ...950

1. A Simple Taxonomy of Conflicts .....................................950

2. Why Interstate Conflicts Are Not "Unworkable" ....................953

a. Eliminating conflict by identifying a single source of law ......954

b. Eliminating conflict by recourse to ordinary conflict-of-laws

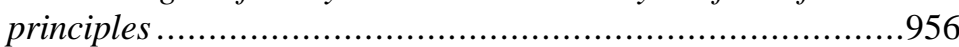

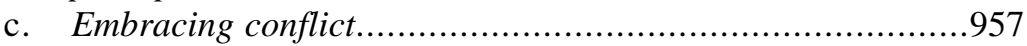

CONCLUSION

.958

\section{INTRODUCTION}

It is commonly understood that as a matter of federal law, states may have divergent substantive policies with respect to those matters that are not violative of the United States Constitution. Such diversity among polities is one of the frequently heralded benefits of our federal system. ${ }^{1}$ As a practical matter, however, what degree of political heterogeneity among states is possible vis-à-vis substantive policies that are not unconstitutional? In short, what is the degree of legal pluralism that our Constitution's federal regime permits?

The answer to the question turns in large part on whether states, if they so choose, can regulate their citizens even when they are out of their Home States. $^{2}$ If they cannot, citizens can bypass their Home States' laws by simply traveling to a more legally permissive state to do there what is prohibited at home. Such "travelevasion," which in effect gives citizens the power to choose which state's laws are to govern them on an issue-byissue basis, can cripple the ability of states to acomplish constitutional

\footnotetext{
1 See, e.g., Elizabeth S. Anderson \& Richard H. Pildes, Expressive Theories of Law: A General Restatement, 148 U. PA. L. REV. 1503, 1558 (2000) (stating that a good associated with federalism is the "diversity of choices [it] permits").

2 The Article refers to the place where the traveler lives as the "Home State" and the place to where she has traveled as the "Host State."
} 
objectives. Consider, for example, how travel-evasion can frustrate legislation banning assisted suicide: the state's interests that drive such a law are undermined if one of its sick citizens takes a bus to a jurisdiction that allows her to end her life. As this Article explains, such travel-evasion may have the systemic effect of creating a "race-to-the-bottom" to the lowest common denominator of regulation, thereby undercutting the degree of political heterogeneity possible among states in our federal system among policies that are not foreclosed to states by the United States Constitution. On the other hand, a Home State's direction of its citizens' out-of-state activities can run up against the interests of the Host State, and, for many other reasons, may threaten to undermine our federal system. How the interests of the Host State, Home State, and the federal system are to be accommodated is the subject of this Article.

There are many constitutionally legitimate state goals that can be frustrated if citizens can free themselves of their Home State's legal requirements merely by crossing a border. For example, those states that require motorcyclists to wear helmets typically do so to protect both their citizens' health and the state's coffers (since badly injured people require medical assistance, may become public charges, etc.). Of course, the state's interests are no less implicated if one of its bare-headed citizens is injured while motorcycling in a sister jurisdiction without helmet laws. So can a state require that its citizens wear helmets when riding motorcycles wherever they might be? Consider as well:

- A state may ban gambling altogether for moral reasons, to prevent the costs imposed on gamblers' families, or to reduce the creation of public charges. $^{3}$ Since such policy goals are undermined regardless of where the citizen's gambling occurs, can a Home State ban its citizens from gambling not only at home but also in all other states?

- Many states have refused to accept the battered spouse defense for wives that kill their battering husbands (and vice versa). Is a Home

3 See Greater New Orleans Broad. Ass'n v. United States, 527 U.S. 173, 185-87 (1999) (noting that the federal government may assist states in their assertion of a "legitimate and substantial interest" in alleviating the societal ills of "injury and loss to [compulsive] gamblers as well as their families, communities, and government").

${ }^{4}$ This Article does not address the question of whether and to what extent states can regulate their citizens' behaviors in foreign countries. The time required by, and costs of, international travel make interstate travel the major means by which citizens attempt to evade their Home State's laws. To be sure, extraterritorial interstate regulation might lead to increased efforts of citizens to leave the country to escape the force of their Home State laws. States' powers are more limited internationally insofar as they may interfere with the federal government's powers over foreign affairs. See Crosby v. Nat'l Foreign Trade Council, 530 U.S. 363, 388 (2000) (preempting and declaring unconstitutional a state law that imposed sanctions on Burma because the state law conflicted with federal sanctions and law). 
State that does not accept the defense without recourse if a battered husband kills his wife while the couple is on vacation in a Host State that accepts the defense?

- A Home State may prohibit discrimination on the basis of sexual orientation to protect gay men and lesbians and to counteract homophobia by requiring interaction between heterosexuals and homosexuals. Can the Home State apply its regulations to a citizen who runs a business in a state that does not have such an antidiscrimination law? ${ }^{6}$

- It is constitutional for states to enact parental notification laws that protect the interests of the pregnant minor's parents by providing them the "opportunity to consult with [their daughter] in private, and to discuss the consequences of her decision in the context of the values and moral or religious principles of their family." What, if anything, can the Home State do to keep its policy from being skirted by the minor crossing the border?

In fact, a broad array of state laws can be circumvented through travel-laws munning the gamut from citizen welfare and the integrity of government to the conduct of business. This Article explores the circumstances under which states can counter such "travel-evasion" to ensure the efficacy of policies that they are constitutionally permitted to pursue. It suggests that to a large degree they can. For instance, this Article will show that states can regulate extraterritorially to counter all the abovementioned kinds of travel-evasion. ${ }^{9}$

5 This intriguing hypothetical was put forward in Seth F. Kreimer, The Law of Choice and Choice of Law: Abortion, the Right to Travel, and Extraterritorial Regulation in American Federalism, 67 N.Y.U. L. REV. 451, 499 n.169 (1992) [hereinafter Kreimer, Law of Choice]. I discuss it at length infra notes 423-26 and accompanying text.

6 This Article does not consider the converse case of whether a gay man from a Home State with antidiscrimination laws can assert that law against a business located in a state without such laws. That scenario implicates the question of whether and to what extent Home States may regulate noncitizens, a complex query that is beyond the scope of this Article.

7 Planned Parenthood v. Casey, 505 U.S. 833, 899-900 (1992). The Court in Casey upheld a parental notification law. Id.

${ }^{8}$ In fact, this frequently occurs. See, e.g., CRLP: Judicial Bypass Fails Young Women Seeking Abortions, U.S. NEWSWIRE, July 15, 1999 (reporting that a Louisiana woman traveled to Texas to obtain an abortion after her petition for a waiver of Louisiana's parental notification requirement was denied by a Louisiana state court judge), available at LEXIS. See generally Kreimer, Law of Choice, supra note 5, at 455 n.14 (citing newspaper articles enumerating studies that document the extent of travel-evasion to circumvent restrictive abortion regulations).

9 This Article considers states' powers to act unilaterally so as to regulate their citizens' out-of-state conduct. A work-in-progress explores two alternatives to unilateral efforts to regulate extraterritorially: (1) congressional authorization to states to regulate citizens 
The question of extraterritorial regulation to counter travel-evasion is of more than just theoretical interest. Pennsylvania recently prosecuted an adult who helped a pregnant minor travel out of the state to avoid the parental notification requirements of her Home State, ${ }^{10}$ and a few years ago the United States House of Representatives approved a bill that would have made an adult's assistance to such pregnant minors a federal crime. ${ }^{11}$ Consider as well Wisconsin's recent efforts to put small Wisconsin dairy farms on an even playing ground with large Wisconsin farms. Purchasers of raw milk paid premiums to large Wisconsin dairy farms in excess of the economic savings that attended the purchase of milk from large farms. To deprive large Wisconsin farms of financial benefits that were not the result of economic efficiencies and thereby engender fairer competition, Wisconsin prohibited premiums to the extent they exceeded the real economic savings of purchasing milk from large farms. The large Wisconsin farms and milk purchasers then engaged in classic travelevasion: with the express purpose of avoiding the Wisconsin law, they restructured the sales so they technically occurred in Illinois, which did not have such a restriction on premiums. Wisconsin in turn sought to apply its prohibition extraterritorially to such Illinois sales. ${ }^{12}$

These examples notwithstanding, few states have tried to frustrate travel-evasion by regulating their citizens' out-of-state activities. There is

extraterritorially and (2) interstate compacts. Mark D. Rosen, Concurrent Legislative Jurisdiction 40-45 (Jan. 10, 2002) (unpublished manuscript, on file with author). Both alternatives to unilateral state action are difficult to accomplish polit ically, however, and hence are unlikely on their own to adequately protect states' interests. See id. at 40-44 (identifying political and potential constitutional problems with the two alternatives).

${ }^{10}$ Commonwealth v. Hartford, No. 95-98 (Ct. Com. Pl. Sullivan County, Pa. Dec. 5, 1996). Professor Kreimer helpfully points out that Ms. Hartford's conviction was reversed due to improper jury instructions in an unpublished, unreported decision. See Seth F. Kreimer, Lines in the Sand: The Importance of Borders in American Federalism, 150 U. PA. L. REV. 973, 975 n.8 (2001) [hereinafter Kreimer, Lines in the Sand]. Pennsylvania was interested in retrying the case, see Robert L. Sharpe, Supreme Court Drops Appeal over N.Y. Abortion, 22 PA. L. WKLY. 1029, 1029 (1999) (“An upstate Pennsylvania prosecutor said he would likely re-try the case."), however the defendant and the Sullivan County district attorney ultimately entered into an agreement under which Ms. Hartford was to perform the same community service and undergo the same rehabilitative treatment that the court had ordered following her conviction. Telephone Interview with Max P. Little, District Attorney, Sullivan County, Pa. (Dec. 20, 2001).

${ }^{11}$ See House Passes First Federal Criminal Anti-Abortion Measure, U.S. NEWSWIRE, June 30, 1999 (reporting that the House passed the Child Custody Protection Act, H.R. 1218, 106th Cong. (1st Sess. 1999), which would have made it a federal offense to transport a minor across state lines for the purpose of obtaining an abortion if the minor's state of residence required parental involvement in her decision to obtain an abortion), available at LEXIS.

${ }^{12}$ For a discussion and analysis of this case, Dean Foods Co. v. Brancel, 187 F.3d 609 (7th Cir. 1999), see infra Part II.C.2. 
evidence that this paucity of examples is attributable to a perception among the states that they are without power to regulate extraterritorially. ${ }^{13}$ Indeed, the House Bill was condemned in the popular press on such a ground, ${ }^{14}$ and Wisconsin's effort was struck down under the Dormant Commerce Clause by a federal court of appeals. ${ }^{15}$ This Article will suggest that such criticism is misplaced, ${ }^{16}$ and that the court's analysis was erroneous. ${ }^{17}$ I hope in this Article to correct the misperception of state incapacity to regulate extraterritorially, so as to allow states to consider this form of regulation on its merits. ${ }^{18}$

Courts and commentators have asserted several doctrinal objections to state efforts to regulate their citizens' out-of-state conduct. The first claim is that states simply do not have the power to regulate conduct occurring outside their borders. Language from the United States Supreme Court case Bigelow v. Virginia ${ }^{19}$ has been said to support this view. ${ }^{20}$ The Court in Bigelow stated that a "State does not acquire power or supervision over the internal affairs of another State merely because the welfare and health of its own citizens may be affected when they travel to that State." ${ }^{21}$ Similarly, the Arizona Court of Appeals recently held that " "[1]aws have no force of themselves beyond the jurisdiction of the state which enacts them, and can have extraterritorial effect only by the comity of other states." ${ }^{22}$ Much

13 See infra note 32 (discussing cases and materials that support the proposition that states do not have extraterritorial powers).

14 See, e.g., Katha Pollitt, Far from Chile?, NATION, July 27, 1998, at 9 (asking "[s]ince when is one still subject to one's home state's laws in another state?" and arguing that such a law accordingly would be unconstitutional); Editorial, Crossing the Line, PORTLAND OREGONIAN, July 28, 1998, at B8 ("Imagine traveling to Portland from another state, abiding by every local law, then returning to face arrest for your completely legal conduct on Oregon soil ... . [F] ederal lawmakers are [not] justified in using a back-door ploy to interfere with prerogatives of individual states to make laws affecting the people who live within their borders.").

${ }^{15}$ See Dean Foods, 187 F.3d at 620 ("[T]he commerce at issue here occurred wholly outside of Wisconsin, and thus any attempt by Wisconsin to enforce its volume premium rules against it would violate the extraterritoriality principle.").

16 Infra Part II.

17 Infra Part II.C.2.

18 Relevant to analyzing the merits of such extraterritorial regulation is the extent to which a state could enforce such regulations. Concurrent Legislative Jurisdiction, a work-inprogress, analyzes enforcement issues and shows that states would have many efficacious options to ensure compliance with laws that regulate their citizens' out-of-state conduct. Rosen, supra note 9, at 45-46.

19421 U.S. 809 (1975).

20 Professor Kreimer has advanced this view. See Kreimer, Law of Choice, supra note 5, at 460-62 (arguing that Bigelow has strong foundations in American federalism).

21421 U.S. at 824.

22 Bruce Church, Inc. v. United Farm Workers of Am., 816 P.2d 919, 925 (Ariz. Ct. 
Dormant Commerce Clause jurisprudence seems to take a similar approach, as such caselaw announces that states may not enact "extraterritorial legislation" that "directly regulates transactions which take place across state lines.",23 This Article will show that these lines of caselaw do not undermine the well-established and normatively sound jurisprudence that states have inherent power to regulate their citizens' extraterritorial conduct.

A second possible objection to extraterritorial regulation is that even if Home States have some extraterritorial powers with respect to their citizens, they do not have the power to prohibit them from engaging in activities in Host States that are permissible for the Host States' citizens. Professor Seth Kreimer has advanced this view, relying in part on the above-mentioned case of Bigelow to argue that the "tradition of American federalism stands squarely against efforts by states to punish their citizens for conduct that is protected in the sister state where it occurs." 24 Professors Rollin Perkins and Ronald Boyce have proffered comparable arguments. ${ }^{25}$ Professor Lea Brilmayer has come to a similar conclusion, arguing that with regard to issues about which there are sharp moral disagreements among states, such as abortion and the right to die, "the structure of our federal system clearly compels the priority of the territorial state, and ... this priority typically invalidates the residence state's claim to regulate. ${ }^{, 26}$

This Article argues against the positions advanced by Professors Kreimer, Perkins, Boyce, and Brilmayer, as well as the other objections to extraterritorial regulation that have been propounded. ${ }^{27}$ It shows that our

App. 1991) (quoting Huntington v. Attrill, 146 U.S. 657, 669 (1892)).

${ }^{23}$ Healy v. Beer Inst., 491 U.S. 324, 333 n.9 (1989) (quoting Edgar v. MITE Corp., 457 U.S. 624, 641 (1982) (plurality opinion)).

${ }^{24}$ Kreimer, Law of Choice, supra note 5, at 462.

25 See Rollin M. Perkins \& Ronald N. BoyCe, Criminal Law 42 (3d ed. 1982) (" $[\mathrm{N}] \mathrm{o}$ state may punish its citizen for what he does in the exclusive territorial jurisdiction of another state where what was done was lawful.").

26 Lea Brilmayer, Interstate Preemption: The Right to Travel, the Right to Life, and the Right to Die, 91 MICH. L. REV. 873, 876 (1993).

27 To date, a few scholars have concluded that states have powers to regulate their citizens' out-of-state conduct under limited circumstances, but none has comprehensively analyzed the issue of extraterritorial regulation. See C. Steven Bradford, What Happens If Roe Is Overruled? Extraterritorial Regulation of Abortion by the States, 35 ARIZ. L. REV. 87, 170 (1993) (concluding only that there is a "plausible" case on behalf of state extraterritorial power in the discrete context of abortion); Mark P. Gergen, Equality and the Conflict of Laws, 73 IowA L. REV. 893, 907 n.94 (1988) (stating in a footnote that "[s]tates may punish citizens for criminal acts done outside the state"); Donald H. Regan, Siamese Essays: (I) CTS Corp. v. Dynamics Corp. of America and Dormant Commerce Clause Doctrine; (II) Extraterritorial State Legislation, 85 MICH. L. REV. 1865, 1906-08, 1912-13 (1987) (providing incisive but incomplete analysis of extraterritoriality in five pages); William Van Alstyne, Closing the Circle of Constitutional Review from Griswold v. Connecticut to Roe v. Wade: An Outline of a Decision Merely Overruling Roe, 1989 DUKE L.J. 1677, 1684 (spending one page on the 
country's federal union imposes far more modest limitations on states' inherent powers to regulate the extraterritorial conduct of their citizens. The Constitution creates a national union, to be sure, but it is a union of meaningfully empowered states. Meaningful empowerment means that states can take reasonable steps, including extraterritorial regulation, to ensure the efficacy of heterogeneous policies that themselves are not unconstitutional. The political heterogeneity that extraterritorial regulation permits is an affirmative good in a country as large and diverse as ours. (Professor Seth Kreimer provides a rejoinder to my analysis in a commentary immediately following this Article, and the editors of the University of Pennsylvania Law Review were kind enough to allow me an extended footnote to respond. ${ }^{28}$ )

More generally, this Article stands firmly against the current tendency among many important legal scholars to dismiss the significance of subfederal polities. Professor Larry Kramer recently opin ed in the pages of the Yale Law Journal that "few citizens today think of the United States as anything other than a single political community" that "share[s] what is, for practical purposes, a single culture." 29 Professors Edward L. Rubin and Malcolm Feeley come to a similar conclusion ${ }^{30}$ and argue that the only valuable function of states is to "achieve the managerial benefits that flow from decentralizing certain governmental functions." 31 This Article, by contrast, elucidates the importance of allowing rich political heterogeneity among states.

The Article is composed of four Parts. The first Part examines states' presumptive powers to regulate their citizens' out-of-state conduct. These baseline extraterritorial powers are confirmed by the Tenth Amendment and are limited in the first instance by due process, which guarantees that such regulations are fair vis-à-vis individual citizens. Such extraterritorial powers are only presumptive, however, for there are additional federal limitations, which are the subjects of Parts II and III. Part I reviews early Supreme Court caselaw, recent scholarly restatements, and contemporary due process jurisprudence concerning extraterritoriality. In so doing, Part I develops several powerful normative arguments on behalf of the position

issue).

28 Infra note 455.

29 Larry Kramer, Same-Sex Marriage, Conflict of Laws, and the Unconstitutional Public Policy Exception, 106 YALE L.J. 1965, 1989 (1997).

30 See Edward L. Rubin \& Malcolm Feeley, Federalism: Some Notes on a National Neurosis, 41 UCLA L. REV. 903, 945 (1994) (“[T]he United States has one political community, and that political community is the United States.").

$31 \mathrm{Id}$. at 951 . For an explanation of the managerial advantages of decentralization, see $i d$. at 910-13. 
that states have extraterritoriality regulatory powers over their citizens.

Part II reviews several constitutional provisions that tame states' baseline extraterritorial powers in the service of creating a single, federal union of states. These limitations on extraterritoriality emerge from the Privileges and Immunities Clause, the right to travel, and the Dormant Commerce Clause, as well as nontextual structural limitations. Although courts and commentators have correctly recognized that these constitutional constraints limit the extent to which Home States can regulate their citizens' out-of-state activities, their scope has been overstated. Careful analysis shows that these constitutional doctrines place important, but only modest, limitations on state power, and that they leave ample room for Home States to regulate their citizens' out-of-state activities.

As a result of the doctrines explored in Parts I and II, our federal system is one in which both the Home and Host State presumptively have concurrent jurisdiction over any given transaction or occurrence. Part III explores the law that establishes and regulates this system of concurrent jurisdiction. Part III also provides a preliminary explanation as to why this system does not result in anarchy, but instead generally functions smoothly. A short Conclusion follows.

\section{The Presumptive Power of Home States to Regulate Their Citizens' Out-OF-STAte Conduct}

As a matter of federal constitutional law, states have a presumptive power to regulate their citizens' extraterritorial conduct. This is something that many state courts appear not to appreciate. ${ }^{32}$ This extraterritorial power

32 See, e.g., Bruce Church, Inc. v. United Farm Workers of Am., 816 P.2d 919, 925-26 (Ariz. Ct. App. 1991) (concluding that states are without extraterritorial power as a matter of federal constitutional law); supra note 22 and accompanying text (discussing the issue concluded in Bruce Church). For a review of cases showing state courts' "attitude of territoriality," which had led the courts to refrain from applying state laws to extraterritorial activities, see Daniel L. Rotenberg, Extraterritorial Legislative Jurisdiction and the State Criminal Law, 38 TEX. L. REV. 763, 773 \& n.59, 774-80 (1960). Similarly, many jurisdictions that have abandoned strict territorialist conflict-of-laws rules and have applied Home State laws concerning loss-allocation to out-of-state occurrences are nonetheless of the view that the Home State could not regulate the conduct of its out-of-state citizens. See, e.g., Babcock v. Jackson, 191 N.E. 279, 284 (N.Y. 1963) (applying New York guest statute to accident occurring out of state). For example, the court in Babcock stated that if the legal issue had

related to the manner in which the defendant had been driving his car at the time of the accident ... it [would be] appropriate to look to the law of the place of the tort so as to give effect to that jurisdiction's interest in regulating conduct within its borders, and it would be almost unthinkable to seek the applicable rule in the law of some other place.

Id. The distinction between "conduct regulating" and "loss allocating" rules is widespread in 
is part of the inherent sovereign powers that have been retained by states under the Tenth Amendment. While the scope of these presumptive powers is limited by contemporary due process doctrine, states retain significant extraterritorial powers vis-à-vis their citizens.

\section{A. Early Caselaw}

As a matter of federal law, ${ }^{33}$ states' regulatory powers do not end at their borders. Under appropriate circumstances, states have the power to apply their laws to their citizens' out-of-state activities. Though the Article's focus is on extraterritorial regulation of citizens, any study of state extraterritoriality powers must start with an early case that upheld Michigan's criminal prosecution of a noncitizen who had never entered the state. The defendant in the 1921 case of Strassheim v. Daily had engaged in bribery and false pretenses in Illinois as part of a scheme to sell used machinery to the state of Michigan that he falsely claimed was new. ${ }^{34}$ Writing for the United States Supreme Court, Justice Holmes famously declared that "[a]cts done outside a jurisdiction, but intended to produce and producing detrimental effects within it, justify a State in punishing the cause of the harm as if he had been present at the effect. ${ }^{, 35}$ Unfortunately, Strassheim is not particularly helpful in explaining the source of the state's extraterritorial powers; it merely says that "the usage of the civilized world would warrant Michigan in punishing him, although he never had set foot in the State until after the fraud was complete. ${ }^{, 36}$ As we soon will see, subsequent cases have more fully developed the proposition that a state has the power to protect itself from harm that is directed against it from outside its borders.

The Supreme Court upheld another state's exercise of extraterritorial jurisdiction in Skiriotes $v$. Florida. ${ }^{37}$ The Court approved the application of

conflict-of-law doctrine. See generally Russell J. Weintraub, Commentary on the CONFLICT OF LAWS 434-35 (4th ed. 2001) (describing how choice-of-law issues are determined in New York and Louisiana depending on this distinction). To the extent this caselaw is premised on the view that federal constitutional law precludes conduct regulating extraterritorial regulation, this Article suggests these criminal law and choice-of-law doctrines could be different. Whether they should be different, of course, is ultimately a matter for states to decide on the merits.

33 State extraterritorial powers under federal law are permissive rather than mandatory; thus, a state court could legitimately conclude that state law precludes a state from regulating extraterritorially.

\footnotetext{
34 221 U.S. 280, 281-82 (1911).

$35 I d$. at 285.

36 Id. at $284-85$.

37313 U.S. 69 (1941).
} 
a Florida statute prohibiting sponge fishing to a Florida citizen's activities that occurred wholly outside of that state's territorial waters. In contrast to Strassheim's epigrammatic discussion, however, the bulk of the Skiriotes opinion concerned the source of the state's power to regulate outside its borders and focused on a two-step explanation. The Court first observed that the federal government has inherent extraterritorial power over activities implicating "legitimate interests" when those interests can be undermined by activities that occur outside of United States territory:

[T]he United States is not debarred by any rule of international law from governing the conduct of its own citizens upon the high seas or even in foreign countries .... Thus, a criminal statute dealing with acts that are directly injurious to the government, and are capable of perpetration without regard to particular locality, is to be construed as applicable to citizens of the United States upon the high seas or in a foreign country ....

Second, the Court analogized the states' sovereign powers to those of the federal government and concluded that the states likewise have extraterritorial regulatory authority. The Court's reasoning turned on the Tenth Amendment in concept, though not in name: the Court states that "[s]ave for the powers committed by the Constitution to the Union, the State of Florida has retained the status of a sovereign,",39 and the "residuum of sovereignty" (the power to regulate its citizens' extraterritorial conduct) was " not delegated to the United States by the Constitution itself.", Accordingly,

[i]f the United States may control the conduct of its citizens upon the high seas, we see no reason why the State of Florida may not likewise govern the conduct of its citizens upon the high seas with respect to matters in which the State has a legitimate interest and where there is no conflict with acts of Congress. $^{41}$

Four aspects of Skiriotes merit further exploration if we are fully to understand the scope of the decision's holding in respect of extraterritoriality. First, the opinion turned on the fact that the person who was subject to regulation was a citizen of the regulating polity. The

38 Id. at $73-74$

39 Id. at 77.

40 Id. (quoting Coyle v. Smith, 221 U.S. 559, 567 (1911)). For an example of a case where the Court explicitly tied this type of argument to the Tenth Amendment, see Heath $v$. Alabama, 474 U.S. 82 (1985), where the Court argued that states' "powers to undertake criminal prosecutions derive from separate and independent sources of power and authority originally belonging to them before admission to the Union and preserved to them by the Tenth Amendment." Id. at 89.

41 Skiriotes, 313 U.S. at 77. 
Skiriotes opinion repeatedly stressed that the regulated party was a citizen, ${ }^{42}$ and the Court distinguished an earlier case on the basis that it concerned one state's effort to regulate the citizens of another state. ${ }^{43}$ This is not to suggest that citizenship is a necessary condition for extraterritorial regulation; consider Strassheim. ${ }^{44}$ Nonetheless, Skiriotes shows that citizenship is a significant factor in assessing the constitutionality of extraterritorial regulation.

Second, one might ask whether the Skiriotes decision, which concerned a criminal statute, has application to the civil context. The answer is in the affirmative, but the line of reasoning is more complicated than might first appear. Although one might be tempted to say that extraterritorial civil authority follows a fortiori from such criminal authority insofar as government typically is subjected to stricter requirements in the criminal context, where a person's liberty is at stake, there are two respects in which criminal law might be thought to justify state extraterritorial power more readily than civil law.

First, one could argue that criminal law by its nature is concerned with vindicating the public interest, and accordingly falls within the sovereign's inherent powers, whereas civil law addresses merely private interests. ${ }^{45}$ This objection is far too broad, however, for the civil law also can be a vehicle for vindicating public interests; ${ }^{46}$ consider, for example, marriage and divorce law. It also ignores the fact that the legislature's choice between civil and criminal penalties cannot be so facilely explained in a regulatory state, such as ours, that charges executive agencies with pursuing noncriminal actions.

Second, and more plausibly, it could be said that extraterritorial

42 See, e.g., id. at 76 (rejecting the view that "the State could not prohibit its own citizens from use of the described divers' equipment at that place" and stating that "[t]he question is solely between appellant and his own State").

${ }^{43}$ Id. at 76-77 (distinguishing the case of Manchester v. Massachusetts, 139 U.S. 240, 242 (1891), because $\mathfrak{t}$ involved Massachusetts' effort to enforce regulations "as against citizens of Rhode Island").

44 See Strassheim v. Daily, 221 U.S. 280, 284-85 (opining that a state can be warranted in punishing a defendant who defrauded it, "although he never had set foot in the State until after the fraud was complete" and thus was not a citizen at the time of the crime).

${ }^{45}$ See, e.g., Huntington v. Attrill, 146 U.S. 657, 657 (1892) (stating that the criminal law's "purpose is to punish an offense against the public justice of the state" whereas civil law "afford[s] a private remedy to a person injured by the wrongful act"); see also id. at 668 (stating hat the criminal law concerns "wrong[s] to the public [rather than] to the individual").

${ }^{46}$ Cf. Sherrer v. Sherrer, 334 U.S. 343, 362 (1948) (Frankfurter, J., dissenting) (“[T]he State also expresses its sovereign power when it speaks through its courts in a civil litigation between private parties."). 
application of civil law is problematically complicated insofar as it concerns the citizen's relationships with other private parties; criminal law is more simple because it primarily concerns the regulated party's relationship with her home polity. This second critique is also too broad because many civil regulations effectively concern only the regulated party's relationship with her home polity, and many criminal laws have direct effects on third parties. It nonetheless highlights an important consideration: the state's extraterritorial powers in respect of its citizens may well vary depending on whether the polity seeks to regulate its citizen's relationship with other private entities (particularly noncitizens) ${ }^{47}$ or whether the state is regulating its bilateral relationship with its own citizens.

In the end, then, Skiorites' holding cannot be said to be applicable only to criminal laws. Many civil laws also advance the state's legitimate interests and primarily concern the bilateral relationship between polity and regulated actor, and Skiriotes' holding concerning extraterritorial regulation is fully applicable to these types of noncriminal laws. Moreover, as I will soon show, the Supreme Court has since upheld the extraterritorial application of state law to noncitizens. ${ }^{48}$

To continue with our analysis of Skiriotes' holding, the case concerned regulation on the high seas, and some commentators have suggested that its holding is limited to this context. ${ }^{49}$ The Court's reasoning, however, is not so confined. As discussed above, the holding turned on the sovereign's inherent powers to guard its "legitimate interest[s]" ${ }^{, 50}$ against injuries that can be "perpetrat[ed] without regard to particular locality," and this logic extends beyond activities that are performed on the high seas. ${ }^{51}$ Indeed, the opinion explicitly referred to the legitimacy of regulations being applicable in "foreign countries." 52

Finally, the Court in Skiriotes made clear that the extraterritorial power

47 See infra notes 79-81 and accompanying text (discussing Home Insurance Co. v. Dick, 281 U.S. 397 (1930))

${ }^{48}$ See infra note 94 (mentioning Watson v. Employers Liability Assurance Corp., 348 U.S. 66 (1955)). In the future, I hope to explore the extent of state extraterritorial regulatory power over noncitizens. Such regulations implicate fundamentally different questions than the question addressed here, i.e., Home State extraterritorial powers vis-à-vis its citizens.

49 See Kreimer, Law of Choice, supra note 5, at 475 \& n.79 (citing books and periodicals that would limit the Skiriotes' holding to maritime law); Seth F. Kreimer, "But Whoever Treasures Freedom ...": The Right to Travel and Extraterritorial Abortions, 91 Mich. L. REV. 907, 925 (1993) [hereinafter Kreimer, Whoever Treasures Freedom] ("Skiriotes is specifically limited to state prosecution of crimes 'within no other territorial jurisdiction."” (quoting Skiriotes, 313 U.S. at 78)).

${ }^{50}$ Skiriotes, 313 U.S. at 77.

51 Id. at 74.

${ }^{52}$ Id. at 73. 
of the United States, and hence also of the states, is not without limits. ${ }^{53}$ Namely, the extraterritorial regulation by states cannot lead to problematic conflicts with federal law; ${ }^{54}$ it is in this sense that the extraterritorial power over citizens is only presumptive. The Court spoke of the United States' undoubted extraterritorial powers "when the rights of other nations or their nationals are not infringed." $" 55$ Although the Court did not elaborate what constituted problematic "infringe[ment]," the Court understood that the application of U.S. law in foreign countries does not per se infringe foreign rights, for Skiriotes contemplated that application of U.S. law in foreign countries would be acceptable at least sometimes. ${ }^{56}$

The question then becomes what if any power states have to regulate their citizens when they are in sister states. Skiriotes makes clear that federal and state extraterritorial legislative powers are comparable, but the question is whether the sister states are analogous to foreign countries for these purposes. The likely answer is both yes and no. On the one hand, the intrinsic need - and power - of the sovereign to guard its legitimate interests by extraterritorially regulating its citizens in respect of activities whose locus is irrelevant to the state interest is, by definition, unaffected by where the activity occurs. For this reason, Skiriotes supports the conclu sion that states enjoy such a presumptive power of extraterritorial regulation over their citizens. ${ }^{57}$ On the other hand, what constitutes a problematic "infringe[ment]" certainly differs as between foreign countries and sister states. Under Skiriotes' approach, the way to identify the limitations on states' extraterritorial powers vis-à-vis sister states ${ }^{58}$ is to consider what sovereign powers were delegated to the federal government in the Constitution and accordingly not retained by the states under the Tenth Amendment. These limitations - constitutional constraints imposed by due process, full faith and credit, privileges and immunities, the right to travel, the Dormant Commerce Clause, and any structural constitutional

${ }^{53} I d$. at $78-79$.

${ }^{5} \mathrm{Id}$.

$55 I d$. at 73 (emphasis added). The Court expressly extended the federal analogy to the states, noting that there was "[n]o question as to the authority of the United States over these waters" and that "[n]o right of a citizen of any other State is here asserted." Id. at 76.

${ }^{56} I d$. at 73 ("[T]he United States is not debarred by any rule of international law from governing the conduct of its own citizens upon the high seas or even in foreign countries when the rights of other nations or their nationals are not infringed." (emphasis added)).

57 See Mark P. Gergen, Equality and the Conflict of Laws, 73 IOWA L. REV. 893, 907 n.94 (1988) (coming to same conclusion).

58 Different principles are relevant to considering states' powers over their citizens' conduct in foreign countries. See Crosby v. Nat'l Foreign Trade Council, 530 U.S. 363, 263 (2000) (preempting a Massachusetts law concerning trade with Burma because of a conflict with federal trade policy). 
limitations - are different from the limitations upon the federal government in the international context and are explained in Parts II and III. It is critical to recognize, however, the analytical distinction between presumptive extraterritorial powers and federal limitations on such powers; the mere fact that a state may be without the power to extraterritorially regulate its citizens in one context does not mean that states are generally without such powers.

\section{B. Scholarly Restatements}

Relying on Strassheim and Skiriotes, scholarly restatements of the law reflect the understanding that states have a presumptive extraterritorial power to criminally and civilly regulate their citizens' out-of-state conduct where the state's legitimate interests are implicated by the extraterritorial conduct. The Restatement (Third) of Foreign Relations Law provides that states "may apply at least some laws to a person outside [state] territory on the basis that he is a citizen, resident or domiciliary of the State. ${ }^{, 59}$ The Restatement asserts that this principle applies to both extraterritorial criminal and civil legislative powers. ${ }^{60}$ Directed to the criminal context, the Model Penal Code provides that State $A$ may impose liability if "the offense is based on a statute of this State that expressly prohibits conduct outside the State." ${ }^{, 61}$ State $A$ has extraterritorial legislative jurisdiction even if the

59 Restatement (ThiRd) OF Foreign RELATIONS LAW § 402 reporters' notes at 5 (1986). The reporters' notes make clear that the Restatement's authors understood its principles to apply to the extraterritorial powers enjoyed by states within the United States. See id. (citing inter alia to Skiriotes and Strassheim, and stating that the "exercise of jurisdiction to prescribe by States is governed by the same principles whether the exercise of jurisdiction has international or inter-State implications"). The reporters' notes state that such extraterritorial legislative jurisdiction generally "involve[s] acts or omissions that also had effect within the State." Id. Professor Kreimer criticizes the Restatement on the ground that states stand in a different relation vis-à-vis sister states than does the United States vis-à-vis other countries. Kreimer, Law of Choice, supra note 5, at 488 n.122. I agree that the "same principles" are not operative in the two very different contexts of domestic and international extraterritoriality, but the Restatement recognizes that the precise scope of extraterritorial powers may differ, as well. See RESTATEMENT (ThiRD) OF ForEIGN RELATIONS LAW § 402 reporters' notes at 5 (1986) ("In exercising jurisdiction to prescribe, a State must take account also of constitutional and other limitations governing judicial enforcement of its laws, particularly in criminal cases."). Parts II and III of this Article examine the federalism-based principles that limit the exercise of states' extraterritorial powers domestically. The Restatement's point concerning state exterritorial regulatory power, accordingly, remains valid.

60 The Restatement is explicit about this. See Restatement (THIRD) OF ForEIGN RELATIONS LAW $\S 403 \mathrm{cmt}$. f (1986) ("The principles governing jurisdiction to prescribe set forth in $\S 402$ and in this section apply to criminal as well as to civil regulation.").

${ }^{61}$ Model Penal CODE $§ 1.03(1)(f)$ (1985). 
activity it prohibits occurs in a state in which the activity is permissible. ${ }^{62}$ The major limitation identified by the Model Penal Code is that the regulated conduct must "bear[] a reasonable relation to a legit imate interest of [the regulating] State." ${ }^{, 63}$ The comment states that the "reasonable relation to legitimate interests" requirement "expresses the general principle of the fourteenth amendment limitation on state egislative jurisdiction.",64 These Model Penal Code provisions have been in whole or in significant part adopted by many states. ${ }^{65}$

\section{Due Process}

Skiriotes did not invoke the term "due process" but instead deployed a freewheeling constitutional inquiry bereft of citation to the Constitution. As suggested by the comment to the Model Penal Code, the extent of a state's presumptive legislative jurisdiction today is analyzed under the doctrinal rubric of due process. Under the modern doctrine articulated in Phillips Petroleum Co. v. Shutts, the Due Process Clause "prohibit[s] the application of law which [is] only casually or slightly related to the litigation."66 More specifically, Shutts requires " a significant contact... creating state interests, such that choice of its law is neither arbitrary nor fundamentally unfair.",67 A careful examination of the caselaw, immediately following in Subsections 1 and 2, reveals that citizenship on its own virtually suffices to give the Home State sufficient interest to regulate its citizens' out-of-state activities. The caselaw also suggests that even when a citizen is not involved, states frequently have the power to exercise legislative jurisdiction over persons whose out-of-state activities undermine legitimate state interests. Taken together, it follows that states have a sufficient interest for due process purposes to regulate their citizens' out-of-state activities that are undertaken for the purpose of evading, or have the effect of undermining, legitimate state policies. This logic establishes, however, only a presumptive, and not an absolute, power to extraterritorially regulate, for there are constitutional limitations outside of due process reflecting the

${ }^{62} I d . \S 1.03(2)$. For a discussion of $\S 1.03$, see infra text accompanying notes $398-405$.

63 Id. $\S 1.03(1)(\mathrm{f})$.

${ }^{64} I d . \S 1.03 \mathrm{cmt}$. 6 . The comment, however, neglects to consider other constitutional limitations that bear on the constitutionality of a state's extraterritorial regulation. See infra Parts II and III (discussing constitutional limitations on a state's extraterritorial legislative powers).

65 E.g., Ariz. Rev. Stat. § 13-108 (A)(5) (2001); 18 Pa. Cons. Stat. ANn. § 102 (6)(a)-(b) (West 1998).

66472 U.S. 797, 819 (1985).

${ }^{67}$ Id. at 818 (quoting Allstate Ins. Co. v. Hague, 449 U.S. 302, 312-13 (1981)). 
federal character of our nation that also constrain states' extraterritorial powers. These limitations will be explored in Parts II and III.

\section{Citizenship}

As both a commonsense and doctrinal matter, citizenship is a significant factor for purposes of legitimating state regulation. Writing for a plurality of the Court in Allstate Insurance Co. v. Hague, for example, Justice Brennan observed that "[n]umerous cases have applied the law of a jurisdiction other than the situs of the injury where there existed some other link between that jurisdiction and the occurrence. ${ }^{, 68}$ Continued Justice Brennan, "[t]he injury or death of a resident of State $A$ in State $B$ is a contact of State $A$ with the occurrence in State $B .{ }^{, 69}$

This is not to suggest that citizenship on its own justifies regulation. In fact, the Court in Hague construed the early case of Home Insurance Co. v. Dick ${ }^{70}$ as standing for the proposition that "nominal residence-standing alone-[is] inadequate." "71 Careful analysis of the caselaw, however, suggests that although "nominal residence" might not suffice, little more than bona fide citizenship is required to justify extraterritorial legislative powers for states.

In Hague, for example, the Supreme Court held that Minnesota could apply its insurance law even though the accident giving rise to the insurance claim had occurred in Wisconsin, the decedent and his widow had lived in Wisconsin at the time of the accident, all relevant vehicles had been registered in Wisconsin, and the insurance policy had been issued in Wisconsin. ${ }^{72}$ According to the Court, Minnesota had three contacts with the parties and occurrence that justified that state's legislative jurisdiction: the widow had become a bona fide Minnesota resident prior to the start of the litigation; the decedent had commuted to and worked in Minnesota; and, Allstate Insurance Company did business in Minnesota. ${ }^{73}$

Minnesota's interest in the widow is clear: obtaining "full compensation" for the survivors of accidents so as to keep them "off welfare rolls" "and to ensure they can " "meet financial obligations.", "The other contacts, however, are at best modest in relation to the issue of

68449 U.S. 302, 314 n.19 (1981).

${ }^{69} I d$. at 315 n.20.

70 281 U.S. 397 (1930).

71 Hague, 449 U.S. at 311 . For my alternative explanation of the Dick case, see infra notes 79-86 and accompanying text.

72449 U.S. at $305-06$.

73 Id. at $313-19$.

${ }^{74}$ Id. at 319 (quoting Hague v. Allstate Ins. Co., 289 N.W.2d 43, 49 (Minn. 1978)). 
Minnesota's power to regulate out-of-state occurrences concerning its citizens. $^{75}$ Allstate's presence in Minnesota is relevant to the fairness of regulating a noncitizen third party, but it is in no respect relevant to the fairness of Minnesota regulating its citizens' extraterritorial conduct. The final contact cited by the Hague Court - that the decedent had worked in Minnesota - is equally dubious with respect to Minnesota's regulatory interest in this context. The decedent had not been commuting to or from work at the time of the accident. ${ }^{76}$ Nor does the Court's explanation that Minnesota had an interest in the safety and well-being of its work force, including its nonresident employees, ${ }^{77}$ in any way explain the basis for Minnesota to apply its insurance stacking laws in the case, for "permitting stacking will not further this interest. ${ }^{, 78}$

In the end, then, Minnesota's interest in applying its law would appear to be wholly derivative of its legitimate interest in its bona fide resident. That this is true is suggested by considering whether Minnesota could have persuasively claimed an interest in applying its insurance stacking laws had the widow remained a resident of Wisconsin; it is hard to imagine that the Court would have accepted such a claim.

In short, Hague suggests that bona fide residence on its own is virtually, if not wholly, a sufficient basis for empowering a state to regulate that person's out-of-state activities. How does this square with Dick? ${ }^{79}$ One response might be that Dick concerned only "nominal residence," as Hague said. ${ }^{80}$ This explanation turns out to be inadequate, however, because what made Dick's Texas residence only "nominal"? It was not that Texas was

75 See also WeINTRAUB, supra note 32, at 593 (noting that Mrs. Hague's residence gave Minnesota an interest but suggesting that "if it were not for the prior commuting and business contacts [of her deceased husband], even the plurality in Hague probably would have thought it so outrageous as to be unconstitutional for Minnesota to assert this late acquired interest in compensation"); cf. Lea Brilmayer, Legitimate Interests in Multistate Problems: As Between State and Federal Law, 79 MICH. L. REV. 1315, 1341 -47 (1981) (arguing that Minnesota had no relevant interests in Hague); Gene R. Shreve, In Search of a Choice-of-Law Reviewing Standard-Reflections on Allstate Insurance Co. v. Hague, 66 MINN. L. REV. 327, 352-53 (1982) (same)

76 Hague, 449 U.S. at 314.

77 Id.

78 Id. at 339 (Powell, J., dissenting). More completely, Justice Powell stated:

The insured's place of employment is not, however, significant in this case. Neither the nature of the insurance policy, the events related to the accident, nor the immediate question of stacking coverage is in any way affected or implicated by the insured's employment status.... Minnesota does not wish its workers to die in automobile accidents, but permitting stacking will not further this interest.

Id.

79281 U.S. 397 (1930).

${ }^{80}$ Hague, 449 U.S. at 311. 
not his bona fide residence; the Court observed that Dick's "permanent residence was in Texas. ${ }^{, 81}$ What made it nominal in the eyes of the Hague Court, presumably, was that all things in regard to the formation of the insurance contract and the underlying events giving rise to the claim occurred outside of Texas and that "[a]t all times here material, he was physically present and acting" outside of Texas. ${ }^{82}$ But what difference should that make to Texas's interest in the matter? After all, the substantive issue was one in which Texas well could have had a strong interest. At issue in Dick was whether a Texas law that prohibited stipulations in insurance contracts limiting time for suits to periods shorter than two years was to apply to an insurance contract negotiated out of state that contained a one-year limitation. ${ }^{83}$ Thus, at stake was whether Dick would be able to file suit to recover insurance for his tug, which had been totally destroyed in a fire. ${ }^{84}$ The loss of property and means of livelihood could well have jeopardized Dick's ability to meet his financial obligations in Texas. Consequently, just like the Home State in Hague, Texas had an interest in applying its laws; namely, a desire to ensure that survivors of accidents who are citizens of the Home State can "meet financial obligations." Texas had as much interest in Dick as Minnesota had in the widow in Hague.

Properly understood, the basis for the Dick decision was not that Texas had no interest in Dick, but that Texas had no right to regulate noncitizensthe insurance companies - that had absolutely no contacts with Texas. The insurance contracts had been negotiated out of Texas, in jurisdictions where one-year suit limitations were legal, and the tug fire occurred outside of Texas as well. In short, Texas's effort to legislate extraterritorially failed not because of Dick's "nominal residence," but because of the regulation's third-party effects on noncitizens. Dick thus teaches nothing about a state's inherent powers to regulate its citizens' out-of-state activities. In fact, the Dick Court, speaking through Justice Brandeis, explicitly said as much: "We need not consider how far the State may go in imposing restrictions on the conduct of its own residents.... It may not abrogate he rights of parties beyond its borders having no relation to anything done or to be done within them. ${ }^{.86}$

81

Dick, 281 U.S. at 408.

82 Id.

83 Id. at 406-11.

84 Home Ins. Co. v. Dick, 8 S.W.2d 354, 355 (Tex. Civ. App. 1928), rev'd, 281 U.S. 397 (1930).

85 Hague v. Allstate Ins. Co., 289 N.W.2d 43, 49 (Minn. 1978).

86 Dick, 281 U.S. at 410 (emphasis added). Professor James Martin has argued that Dick 
Since Dick was decided, citizenship has been weighted even more heavily to justify what is best characterized as extraterritorial regulation. In Clay v. Sun Insurance Office, Ltd., ${ }^{87}$ for example, citizenship was a basis for overriding the express expectations of the contracting parties. An Illinois citizen had purchased from a non-Illinois company an insurance policy that required that any lawsuits be initiated within twelve months after the occurrence. $^{88}$ The clause was valid under Illinois law. The insured thereafter made a bona fide move to Florida, which had a statute that nullified any insurance clauses requiring suit before five years. ${ }^{89}$ Loss occurred in Florida, and the Supreme Court decided that the contract's twelve-month provision did not apply. ${ }^{90}$ Although the Court suggested that holding otherwise would amount to giving Illinois law extraterritorial application, ${ }^{91}$ the more natural way to conceptualize the operation of the Florida statute is that it operated extraterritorially by altering the contractual rights that had been created by the parties when they formed their contractual obligations in Illinois. ${ }^{92}$ So understood, Clay gave more weight

is best understood as a decision in which " $[\mathrm{t}] \mathrm{he}$ deference is to the sovereignty of Mexico and not to the personal rights of the parties," and hence that the case is best understood not as a due process "fairness" decision but as a full faith and credit type of decision. James A. Martin, Constitutional Limitations on Choice of Law, 61 CoRnell L. REV. 185, 192 (1976); see also id. (emphasizing that due process protects individuals, whereas full faith and credit protects states); $i d$. at 199 (concluding that "Dick does not yield to a due process analysis"). While the case plausibly could have been decided on the principle of deference to sovereigns, Dick plainly was not decided on those grounds. More importantly, it is unclear why the decision need be so reread, for it is sensible on the grounds on which it was decided: there is a strong argument that the noncitizen defendants had no substantial connection to Texas, and therefore that applying Texas law would have been unfair to them and accordingly violative of due process. See WeINTRAUB, supra note 32, at 598 ("[T]he application of Texas law violated due process because the contacts that Texas had with the parties and with the transaction were not sufficient to make it reasonable for Texas to assert the interest that it did have in applying Texas law."). For a critique of Martin's argument, see Frederic L. Kirgis, Jr., The Roles of Due Process and Full Faith and Credit in Choice of Law, 62 CORNELL L. REV. 94, 108-09 (1976) (providing an alternative due process-based explanation of Dick). Professor Martin has not responded to this argument posited by Professor Kirgis. See James A. Martin, A Reply to Professor Kirgis, 62 CORNELL L. REV. 151 (1976) (responding to many of Professor Kirgis's arguments, but not to this one).

87377 U.S. 179 (1964).

88 Id. at 180.

89 Id.

$90 \mathrm{Id}$. at $181-83$

91 See id. at 181 ("While there are Illinois cases indicating that parties may contract —as here-for a shorter period of limitations than is provided by the Illinois statute, we are referred to no Illinois decision extending that rule into other States whenever claims on Illinois contracts are sought to be enforced there.").

92 At the time of the Clay decision, contracts typically were construed under the law of the jurisdiction in which they were made because the contractual obligations were conceptualized as having come into existence at the time of contract formation. See, e.g., 
to citizenship than did Dick, for whereas Dick was concerned with not "increas[ing the parties'] obligation and impos[ing] a burden not contracted for, ${ }^{, 93}$ Clay did that very thing. The key distinction between the cases justifying the different outcomes is that Florida in Clay (unlike Texas in Dick) had a right to regulate the noncitizen because it did business in the state, and was licensed to do so. ${ }^{94}$

\section{State Interest in Thwarting the Subversion of Legitimate State Policies by Out-of-State Activities}

It is well recognized that legitimate state policies frequently can be confounded by out-of-state activities, and regulating such extraterritorial activities has been upheld frequently, even when the regulated parties are not citizens of the regulating polity. This body of caselaw, in conjunction with the cases surveyed above that show the states' significant interests in

John Hancock Mut. Life Ins. Co. v. Yates, 299 U.S. 178, 182 (1936) (holding that a New York statute providing that a false statement in an insurance application regarding medical treatment constitutes material misrepresentation voiding the policy is a "term of the contract," and must be applied by a Georgia court, even though under Georgia law what qualifies as a material misrepresentation is a question for the jury, and stating that "such recognition does not give to the New York statute extraterritorial effect"); RESTATEMENT OF CONFLICT OF LAWS $\S 332$ (1934) ("The law of the place of contracting determines the validity and effect of a promise with respect to [eight specified issues]."). To be sure, the Clay Court tried to sugge st that the insurance company's expectations really had not been disappointed because the " "contract did not even attempt to provide that the law of Illinois would govern when suits were filed anywhere else in the country,", 377 U.S. at 182 (quoting Clay v. Sun Ins. Office, Ltd., 363 U.S. 207, 221 (1960) (Black, J., dissenting)), but such an argument reverses without justification the typical default rule of the time that contracts were to be construed under the law of the jurisdiction of formation.

93 Dick, 281 U.S. at 409.

94 Clay, 377 U.S. at 182 (quoting from Justice Black's dissent in Clay, 363 U.S. at 221, in its holding). In an even more extreme example of citizenship as a basis for extraterritorial regulation than Clay, the Supreme Court in Watson v. Employers Liability Assurance Corp., 348 U.S. 66 (1954), upheld one state's extraterritorial regulation of a contract between two noncitizens because the contract had an impact on a citizen. The Court upheld a Louisiana statute that allowed injured parties to institute a direct action against an insurer " whether the policy of insurance sued upon was written or delivered in the State of Louisiana or not and whether or not such policy contains a provision forbidding such direct action, provided the accident or injury occurred within the State of Louisiana." Id. at 68 n.4 (quoting LA. REV. STAT. ANN. § 22:655 (West 1950)). The insurance policy disallowing direct actions had been negotiated and issued in Massachusetts and Illinois, where such policies were legal, and was between a non-Louisiana insurer and a non-Louisiana insured person. Id. at $67 \&$ n.2. What was the source of Louisiana's interest? The answer is that the injured party was a Louisiana citizen, and Louisiana wanted to maximize its citizens' prospects for recovery. Id. at 72 . In short, the Watson Court allowed Louisiana to conform to Louisiana's statutory requirements a contract negotiated out of its state by noncitizens, thereby altering the express terms of their contract. This de facto extraterritorial regulation was permitted because the contract affected the welfare of a Louisiana citizen. 
regulating their citizens, strongly suggests that preventing citizens from evading legitimate state policies through travel constitutes a legitimate state interest sufficient to support a presumptive power of extraterritorial regulation for purposes of due process.

Activities can harm a polity's interests even if undertaken outside of the polity's physical borders. This can most readily be understood by considering the types of activities generally deemed to fall within the purview of states' regulatory powers. States may seek to protect themselves, to control third-party effects, to guard paternalistically the welfare of their citizens, and to try to manage norm-generation. ${ }^{95}$ Each of these legitimate state interests can be undercut by out-of-state activities. Consider first a state's guarding of its own interests. Speaking in the context of the extraterritorial effect of federal statutes, the United States Supreme Court has recognized that there are "criminal statutes which are, as a class, not logically dependent on their locality for the Government's jurisdiction, but are enacted because of the right of the Government to defend itself against obstruction, or fraud wherever perpetrated, especially if committed by its own citizens, officers or agents." ${ }^{.96}$ With respect to such crimes, said the Court, "to limit their locus to the strictly territorial jurisdiction would be greatly to curtail the scope and usefulness of the statute and leave open a large mmunity for frauds as easily committed by citizens" when they are outside the polity's borders "as at home." 97 This logic readily carries over to the domestic context and can explain the Court's holding in the aforementioned Strassheim case, which upheld Michigan's assertion of jurisdiction over a person who had not entered the state but who engaged in bribery and false pretenses in Illinois as part of a scheme to fraudulently sell used machinery to Michigan. ${ }^{98}$ Similarly, it would make sense that public corruption statutes should prevent a public official from "evad[ing] guilt . . by the simple expedient of stepping across [the] State border for the sole purpose of accepting the money."

95 See Jack L. Goldsmith, Against Cyberanarchy, 65 U. CHI. L. REV. 1199, 1209 (1998) (arguing that jurisdiction and choice-of-law issues do not render the regulation of cyberspace infeasible or illegitimate and noting that "every nation has mandatory laws that govern particular transactions or relationships regardless of the wishes of the parties" and "[t]he primary justifications for such laws are paternalism and protection of third parties"); Cass R. Sunstein, Social Norms and Social Roles, 96 Colum. L. REV. 903, 907, 910 (1996) (arguing that the government and the law are rightfully involved in "norm management," "expressing social values," and "shifting social norms").

${ }^{96}$ United States v. Bowman, 260 U.S. 94, 98 (1922).

97 Id. (emphasis added).

98 Strassheim v. Daily, 221 U.S. 280, $281-85$ (1911).

99 Commonwealth v. Welch, 187 N.E.2d 813, 816 (Mass. 1963). Though the court in Welch justified the application of the Massachusetts statute on the basis that some acts relating 
The police powers-a state's presumptive power to care for the health, welfare, and morals of its citizens-provides another predicate for the extraterritorial regulation of citizens. The Supreme Court has "recognized that a State ha[s] a legitimate interest in protecting the welfare of its citizens as they venture[] outside the State's borders." ${ }^{, 100}$ Consider in this regard the case of In re Busalacchi, ${ }^{101}$ which concerned a father's desire to move his daughter, who was in a persistent vegetative state, from Missouri, under whose laws he could not remove the feeding tube that sustained her life, to a state under whose laws he could more readily withdraw the tube. Did Missouri have a legitimate interest in guarding the daughter's life by blocking the father's plans so he could not simply cross the border to do in Illinois - remove his daughter's feeding tube-what was prohibited at home? A Missouri state appellate court ruled that Missouri, which determined that the guardian, under parens patriae, had such an interest in the daughter's life, ${ }^{102}$ and it is hard to say that the court was incorrect on this point. The court accordingly sustained Missouri's effort to control what the father could legally do regarding his daughter outside of the state.

to the corruption had occurred in Massachusetts, $i d$., the same outcome should have obtained even if all illicit acts had occurred out of state.

With respect to guarding the state's interests, consider as well the analogous context of contempt of court for violation of court orders. As one court stated,

contempt is an offense against the dignity and authority of the particular court, to which the affront is offered. . . [T] he affront is none the less directly against the dignity and authority of that court, no matter to what county or state the offender may go to violate the order of the court. If that were not true, then injunction orders in many instances would be a farce. It would be ridiculous, to say that an order enjoining the sale of personal property, over which the court had jurisdiction, could be violated with impunity, if the litigant only took the pains to cross the state line before disposing of it.

Farmers' State Bank v. State, 164 P. 132, 132 (Okla. Crim. App. 1917).

Virtually the same refrain can be seen in the context of the out-of-state attempted murder of a key witness in a prosecution: "The administration of justice is equally bstructed wherever the act is done ... . The act in its nature is not one dependent upon location for its greater or less influence on the administration of justice." McCaully v. United States, 25 App. D.C. 404,413 (1905).

100 United States v. Edge Broad. Co., 509 U.S. 418, 437 (1993) (Stevens, J., dissenting) (describing an observation in Bigelow v. Virginia, 421 U.S. 809 (1975)).

101 No. 59582, 1991 Mo. App. LEXIS 315 (Mo. Ct. App. Mar. 5, 1991).

$102 \mathrm{Id}$. at $* 7-17$. It is another question as to whether the action of the court - enjoining a father from taking his daughter out of state-should have been upheld. Indeed, it may have run afoul of the right to travel. See infra Part II.B (exploring how the right to travel imposes a limit on states' powers to regulate their citizens' out-of-state activities). An alternative response that would have been justified more easily would have been a Missouri statute criminalizing the act of taking Missouri citizens in persistent vegetative states out of the state for purposes of taking advantage of other states' more lenient laws in respect of removal of feeding tubes. 
In a context analogous to extraterritorial state regulation, the Supreme Court recently has held that states have a legitimate interest in their citizens' out-of-state activities if such activities undermine legitimate state policy. In United States v. Edge Broadcasting Co., the Court upheld a federal statute that prohibited the radio broadcast of lottery advertising by radio licensees located in nonlottery states. ${ }^{103}$ The broadcaster in Edge was located in North Carolina, a nonlottery state, but wanted to broadcast Virginia lottery advertisements. ${ }^{104}$ As part of its analysis, the Edge Court concluded that the statute directly advanced the federal government's interest in "support[ing] the antigambling policy of a State like North Carolina by forbidding stations in such a State to air lottery advertising." ${ }^{105}$ The federal interest that served to uphold the statute thus was wholly derivative of the state's interest, ineluctably leading to the conclusion that the state's interest was legitimate. The Court understood that North Carolina's antigambling policy would have been undermined had the broadcaster been permitted to broadcast advertisements for an activity that was legal in another state but prohibited in North Carolina. In other words, North Carolina's antigambling policy would have been undermined by North Carolina citizens' out-of-state conduct, even if the gambling occurred in a state in which the activity was legal. ${ }^{106}$ The Court's rationale makes sense; an antilottery policy might be based on a conclusion that "lotteries play on the hopes of those least able to afford to purchase lottery tickets, and that its citizens would be better served by spending their money on more promising investments."107 Surely these

103509 U.S. at 418.

104 Id. at 423-24.

105 Id. at 428.

106 One might object to this conclusion by suggesting that all the Court meant is that North Carolina's antigambling policy would have been undermined had advertisements for the activity emanated from North Carolina and that the opinion did not suggest that North Carolina was legitimately concerned with whether its citizens acted out of state on the information conveyed by the advertisement. The reasoning in the Edge opinion defeats this highly counterintuitive explanation of the state's interest. When analyzing whether a reasonable fit existed between the governmental interest and the restriction, the Court stated that the broadcaster's "signals with lottery ads would be heard in the nine counties in North Carolina that its broadcasts reached, [and] this would be in derogation of the substantial federal interest in supporting North Carolina's laws making lotteries illegal." Id. at 429; see also id. at 432-33 (suggesting that many North Carolina residents would not receive information relating to Virginia gambling if Edge were not allowed to broadcast such advertisements). Furthermore, the dissenters in Edge understood the state interest recognized by the majority opinion to be "discouraging its citizens from participating in state-run lotteries," not the elimination of lottery advertisements from broadcasters located on North Carolina soil. Id. at 440 (Stevens, J., dissenting).

107 Id. at 440 n.5 (Stevens, J., dissenting). 
objectives would be undermined regardless of where gambling occurs. ${ }^{108}$

But how broadly should a state's interest in guarding the morals or welfare of its citizens be construed for purposes of determining the state's "legitimate interests" and hence its presumptive extraterritorial powers visà-vis its citizens? Answering the question first requires a recognition that one's conception of what falls within the state's purview concerning its citizens' morals or welfare turns on the deep political theory that one holds. Under classic Aristotelian political philosophy, for example, the core function of the polity is to habituate its citizens to act virtuously. ${ }^{109}$ Aristotle, as well as many neo-Aristotelians who go by the name of communitarians, believe that government plays an essential role in habituating its citizens to virtue, and that without government's assistance people's potential for excellence will go unrealized. ${ }^{110}$ Such a notion that the state is deeply connected to the moral development and character of its citizens is reflected as well in certain strands of republicanism. ${ }^{111}$ In a similar vein, communitarian writers posit that people are partly defined by the communities of which they are a part, and they accordingly argue that politics is naturally and properly concerned with shaping the community's

108 Such a state policy is not inconsistent with the fact that the state was not capable of effectuating an absolute ban on advertising insofar as broadcasters located outside of North Carolina could play lottery advertisements even if their signal came into North Carolina. The inability to realize fully a state's policy due to legal obstacles beyond the state's control does not make the state's attempts to advance that policy constitutionally illegitimate. See Greater New Orleans Broad. Ass'n v. United States, 527 U.S. 173, 195-96 (1999) (holding that a prohibition on broadcasting lottery information could not be applied to gambling advertisements by radio and television stations located in states where such gambling was legal). The Supreme Court's holding in Edge fully supports this sensible point, see 509 U.S. at 429-34 (holding that the state's broadcasting restriction reasonably fit the government interest of supporting North Carolina's antigambling policy even though many North Carolina residents could hear lottery advertisements broadcast by radio stations located outside of North Carolina), as do cases in other contexts, see, e.g., Maine v. Taylor, 477 U.S. 131, 151 (1986) (holding in the Dormant Commerce Clause context that "[t]he impediments to complete success . . . cannot be a ground for preventing a state from using its best efforts" to limit an environmental risk).

109 See Mark D. Rosen, The Outer Limits of Community Self-Governance in Residential Associations, Municipalities, and Indian Country: A Liberal Theory, 84 VA. L. REV. 1053, 1066-68 (1999) [hereinafter Rosen, Outer Limits] (explaining the Aristotelian theory of government).

${ }^{110}$ See A.C. Bradley, Aristotle's Conception of the State, in A ComPANION TO ARISTOTLE's POLITICS 13, 28 (David Keyt \& Fred D. Miller, Jr. eds., 1991) (describing Aristotle's theory of the prominent role of the state in the attainment of virtue). For an example of a prominent self-identifying neo-Aristotelian who also is viewed by many as a communitarian theorist, see ALASDAIR MACINTYRE, AFTER VIRTUE (2d ed. 1984).

${ }^{111}$ See Rosen, Outer Limits, supra note 109 , at $1067 \&$ n.53 (noting that early in American history, public figures expressed the view that republican government required virtue in its citizens). 
character. ${ }^{12}$ Aristotelian, republican, and communitarian views naturally give rise to broad state interests that justify extensive regulation to shape citizens' norms and values. Furthermore, these political philosophies tend to mandate a state regulatory interest in its citizens' activities and behaviors irrespective of where they occur since they inherently reflect an individual's character and hence fall within the state's purview. ${ }^{113}$ By contrast, under popular understandings of liberalism, the state is largely to leave people alone to shape themselves as they deem proper. ${ }^{114}$

Which deep political theory ought to prevail for purposes of identifying legitimate state interests in a due process analysis? The best answer is that our federal system does not mandate a single answer, ${ }^{115}$ but that states can adhere to any of the above political theories and are limited in enacting laws only by discrete federal (and state) substantive constitutional doctrines. This conclusion is consistent with the lessons of Lochner v. New York ${ }^{116}$ concerning the dangers of judicial second-guessing of legislative value judgments through the wholly open-ended vehicle of substantive due process. This conclusion also is essential to preserving one of federalism's great merits: the space it provides for rich political heterogeneity at the subfederal levels of government. The freedom of states to adopt different deep political theories also is confirmed by the Tenth Amendment, which reserves to the states the power to pursue their particular visions of the good. $^{117}$ In short, limitations on such state powers properly come from

\footnotetext{
112 See id. at 1066-67 \& n.52 (describing the communitarian view of "Interconnected Welfare").

113 See Lea Brilmayer, Liberalism, Community, and State Borders, 41 DUKE L.J. 1, 9-26 (1991) (arguing that communitarianism and liberalism support different conceptions of state jurisdiction).

${ }^{114}$ See, e.g., John Rawls, Political Liberalism 307-08 (1993) (singling out necessary "social conditions and all-purpose means to enable persons to pursue their determinate conceptions of the good"); Rosen, Outer Limits, supra note 109, at 1091-92 (discussing Rawls on this point). In tension with this, of course, is the acknowledgment by many that the liberal state deeply shapes citizens' norms. See, e.g., Sunstein, supra note 95, at 907 (suggesting that government inevitably plays a large role in shaping human behavior and "norm management").

115 Cf. CTS Corp. v. Dynamics Corp. of Am., 481 U.S. 69, 92 (1987) ("The Constitution does not require the States to subscribe to any particular economic theory.").

116198 U.S. 45 (1905).

117 Cf. Heath v. Alabama, 474 U.S. 82, 89 (1985) (holding that states' "powers to undertake criminal prosecutions derive from separate and independent sources of power and authority originally belonging to them before admission to the Union and preserved to them by the Tenth Amendment"); id. at 93 ("The Constitution leaves in the possession of each State 'certain exclusive and very important portions of sovereign power.' Foremost among the prerogatives of sovereignty is the power to create and enforce a criminal code." (quoting THE FEDERALIST No. 9, at 55 (Alexander Hamilton) (J.E. Cooke ed., 1961))); Heath, 474 U.S. at 93 (recognizing that "'States . . a as political communities, [are] distinct and sovereign, and
} 
established constitutional provisions and doctrines, such as equal protection and privacy, rather than through appeals to the amorphous Due Process Clause. The "legitimate state interests" test under due process accordingly should not act as a bar to a state's adoption of a political theory under which the state seeks to regulate the morals and character of its citizenry. As long as the regulation does not run afoul of established constitutional doctrines, ensuring that it not be evaded through travel should qualify as a legitimate state interest.

To quickly conclude, many of the policies whose in-state validity is constitutionally unquestioned can be easily thwarted if citizens can free themselves of their Home States' laws by merely exiting their state of residence. Accordingly, states have legitimate interests for purposes of due process in seeking to circumvent such travel-evasion by giving their laws extraterritorial effect over their peripatetic citizens.

\section{Considerations of Fairness: The Normative Case for Extraterritoriality}

The final guarantee of the Due Process Clause is that the choice-of-law decision cannot be fundamentally unfair. ${ }^{18}$ Application of the Home State law to its out-of-state citizen does not per se run afoul of this final protection of due process for two principal reasons. First, it is not unfair for states to ensure the efficacy of constitutionally permissible policies by withdrawing from their citizens the effective power to choose which state's legal regime they are to be governed by on an issue-by-issue basis. States can insist instead that their citizens be subject to their Home State's law for so long as they elect to remain citizens of the state. Second, extraterritoriality has a rational fundamental basis in that it advances the cause of political heterogeneity among states. As we will see, these normative considerations are relevant not only to due process, but to many other constitutional doctrines as well. Therefore, the normative arguments developed below will be drawn upon at many other points in this Article.

\section{a. Ensuring the efficacy of legitimate state laws}

First, extraterritoriality is fair because, as discussed above, it is necessary to ensure the efficacy of many constitutional state policies. ${ }^{119}$ For example, without such power, state laws outlawing gambling or requiring

consequently foreign to each other'" (quoting Bank of United States v. Daniel, 37 U.S. (12 Pet.) 32,54 (1838))).

118 See Allstate Ins. Co. v. Hague, 449 U.S. 302, 308 (1981) (noting that in choice-oflaw questions, fundamental fairness considerations must be satisfied).

119 Supra Part I.C.2. 
parental consent prior to abortions could be readily skirted. Since consent to abide by laws that are lawfully enacted, and to incur the consequences if one does not, is a cornerstone of citizenship, it is fair for a state to expect that its citizens will obey legitimately enacted state laws and regulations, even those laws an individual might not like. ${ }^{120}$ Given this, it is perfectly sensible and fair for a polity to prevent citizens from evading such laws by seeking to avail themselves of different laws through travel. To the extent that the control of third-party effects, the pursuit of paternalism, and the management of the generation of norms are legitimate predicates for lawmaking, it is fair that states are empowered to work against the circumvention of these legitimate objectives by denying their citizens (for so long as they remain citizens) the power to choose by the expedient of travel to be governed by a different State's legal regime.

In fact, there are several contexts in which the law limits individuals' powers to elect to be governed by the law of their choice. This is strong evidence that limiting citizens' powers to avail themselves of different states' laws by curbing travel-evasion is not fundamentally unfair for purposes of due process. Particularly instructive is that the very jurisprudence of due process is one place where these rules are found. For example, in Phillips Petroleum Co. v. Shutts, the Supreme Court considered whether Kansas had sufficient contacts to justify applying its law consistent with the demands of due process. ${ }^{121}$ Among the factors the Court rejected as irrelevant was the plaintiffs' desire to be governed by Kansas law: "Even if a plaintiff evidences his desire for forum law by moving to the forum, we have generally accorded such a move little or no significance .... Thus the plaintiffs' desire for Kansas law . . . bears little relevance.,"122

In two other contexts, protecting the state's ability to advance its policies has explicitly justified limiting citizens' powers to choose the law by which they are to be governed. Consider first the law concerning contractual choice-of-law provisions. Contracts, of course, is a field where the law primarily lays down default rules that the contracting parties are free to reject; "our society confers upon contracting parties wide power to shape

${ }^{120}$ In fact, the Western political tradition long has grounded the duty to obey laws on citizens' implied consent to abide by laws by virtue of their being members of a polity. Mark D. Rosen, Defrocking the Courts: Resolving 'Cases or Controversies,' Not Announcing Transcendental Truths, 17 HARV. J.L. \& PUB. POL'Y 715, 725-26 (1994); LEA BRILMAYER, CONFLICT OF LAWS $241 \&$ n.49 (2d ed. 1995) (citing A. SimMONS, MORAL PRINCIPLES AND Political OBLIgATIONS (1979)). This is a position that might justify extraterritorial regulation even where a citizen's out-of-state activities do not threaten state policy.

121472 U.S. 797, 819 (1985).

122 Id. at 820. 
their relationships." 123 Nonetheless, "[t]he case law generally favors for the enforcement of choice-of-law clauses that the chosen law bear a relationship of some significance to the transaction." 124 The principal justification for this is that without such a requirement "the parties could evade the otherwise applicable local law and thereby render state laws regarding contract validity meaningless." ${ }^{25}$ Some state courts have gone even further and overridden parties' express choice of law where "the state whose law would control in the absence of a choice has a materially greater interest in the subject matter" than the state whose law the parties selected. ${ }^{126}$ These lines of caselaw are consistent with the Restatement (Second) of Conflict of Laws. $^{127}$

A similar concern for not permitting parties to effectively opt-out of laws so as to protect the state's ability to further legitimate policies can be found in the Supreme Court's Contracts Clause jurisprudence. The clause's

123 E. Allan FARnSWORTH, CONTRACTS 426 (3d ed. 1999).

124 Eugene F. SCOles ET AL., CONFliCt OF LAWs 871 \& n.1 (3d ed. 2000) (citing cases).

125 Id.; see also 2 JOSEPH H. BEALE, A T REATISE ON THECONFLICT OF LAWs $\$ 332.2$, at $1079-80$ (1935) (explaining that permitting parties to choose the law that is to govern their contracts would be objectionable private legislation). Professor Kramer recently has argued that "[i]n contract cases, true conflicts should be resolved by applying the law chosen by the parties." Larry Kramer, Rethinking Choice of Law, 90 COLUM. L. REV. 277, 329 (1990). However, he appears to conclude that the parties' choice should be disregarded "if party autonomy threatens completely to undermine domestic policy." $I d$. at 333 . Similarly, although Professors Erin O'Hara and Larry Ribstein recently have put forth a vigorous argument for the expansion of party choice in contractual choice of law provisions, see Erin Ann O'Hara, Opting Out of Regulation: A Public Choice Analysis of Contractual Choice of Law, 53 VAND. L. REV. 1551 (2000) (providing an analysis of when contractual choice-oflaw provisions are beneficial); Erin A. O'Hara \& Larry E. Ribstein, From Politics to Efficiency in Choice of Law, 67 U. CHI. L. REV. 1151, 1164-65 (2000) [hereinafter O'Hara \& Ribstein, From Politics to Efficiency] ("To maximize efficiency, choice-of-law rules should, in general, facilitate individual choice."), they too recognize that there may be "lost benefits resulting from evasion of laws through party choice of law," and conclude that choice-of-law rules should not be given effect when state legislators prohibit enforcement, O'Hara \& Ribstein, From Politics to Efficiency, supra, at 1153, 1164.

${ }^{126}$ See Rosenmiller v. Bordes, 607 A.2d 465, 468 (Del. Ch. 1991) (relying on RESTATEMENT (SECOND) OF CONFLICTS OF LAWS and disregarding the choice of law provision in a shareholders agreement); $i d$. at 469 (concluding that "Delaware therefore has a greater interest than does New Jersey in regulating stockholder voting rights in Delaware corporations," notwithstanding the "parties' express choice of New Jersey law" as the governing law).

127 See RESTATEMENT (SECOND) OF CONFLICT OF LAWS § 187(2)(a)-(b) (1971) (providing that the parties' choice of governing law will be overridden if "the chosen state has no substantial relationship to the parties or the transaction and there is no other reasonable basis for the parties' choice," or if "application of the law of the chosen state would be contrary to a fundamental policy of a state which has a materially greater interest than the chosen state in the determination of the particular issue"). 
prohibition against the enactment of laws by states that "impair[] the Obligation of Contracts" ${ }^{, 28}$ could have had the effect of allowing a citizen to immunize herself from the law by contracting in advance of legislation. A party may claim such legislation could not be applied to her because it would impair the obligation of her contract. Such arguments in fact were made before the Supreme Court, but it was early established that the Contracts Clause

\begin{abstract}
does not prevent the State from exercising such powers as are vested in it for the promotion of the common weal, or are necessary for the general good of the public, though contracts previously entered into between individuals may thereby be affected. . . . Familiar instances of this are, where parties enter into contracts, perfectly lawful at the time, to sell liquor, operate a brewery or distillery, or carry on a lottery, all of which are subject to impairment by a change of policy on the part of the State, prohibiting the establishment or continuance of such traffic .....
\end{abstract}

The Court's reasoning makes sense since "the police power . . is an exercise of the sovereign right of the Government to protect the lives, health, morals, comfort and general welfare of the people, and is paramount to any rights under contracts between individuals." 130 Thus, this doctrine prevents citizens from effectively opting out of their state's regulations through the expedient of contract.

Finally, state power to ensure the efficacy of permissible policies is consistent with the Court's "new federalism" jurisprudence of the last decade. To be sure, the cases to date have involved questions of the federalstate relationship. But the core concern of respecting the states' inherent sovereignty that has animated many of these decisions ${ }^{131}$ provides equal theoretical support for the extraterritorial power to curb travel-evasion. After all, if citizens are allowed to circumvent their Home State laws by merely traveling across state lines, the state's capacity to advance what it deems to be the common interest within the scope of substantive policies that are not precluded by the Federal Constitution-one of the essential aspects of state sovereignty-is importantly undermined.

\title{
b. Political heterogeneity
}

A second reason that extraterritorial powers to curb travel-evasion are

128 U.S. CONST. art. I, § 10, cl. 1.

129 Manigault v. Springs, 199 U.S. 473, 480 (1905).

${ }_{130} I d$.

131 See, e.g., Seminole Tribe of Fla. v. Florida, 517 U.S. 44, 54 (1996) (reasoning that states require Eleventh Amendment immunity from suit to maintain their inherent sovereignty). 
not unfair, but are in fact normatively attractive, is that political heterogeneity among states requires it. A federal system that did not permit extraterritorial regulation to counter travel-evasion would systematically disadvantage states that decide to regulate when others elect not to, perhaps even leading to a "race-to-the-bottom" to the lowest common denominator of regulation. Legal constraints mposed for reasons of paternalism or norm-generation may be rendered ineffective if citizens could simply cross a border to avail themselves of a different legal regime. This is self-evident with respect to paternalistic policies that are intended to protect citizens from themselves; such policies cannot succeed if the citizens can cross the border to undertake the activity in a lenient jurisdiction.

Consider as well the effect of ignoring the Home State's interests in norm-generation. Under many theories, people's moral sensibilities are significantly shaped by the behaviors of people they know and with whom they regularly interact. ${ }^{132}$ A state, accordingly, may be unable to impress a norm on its citizens if large numbers of them are engaging in the locally proscribed activity in a place where it is permitted. Importantly, this may even be irreversible in the short run; once people start engaging in the behavior, the possibility of inculcating a contrary norm might be lost. In short, travel-evasion may reduce political heterogeneity across states with respect to policies that are not foreclosed by the United States Constitution by rendering less permissive state laws ineffective. Additionally, this would have the corollary consequence of hindering the extent to which different states could experiment with different legal regimes, a related benefit of federalism. ${ }^{133}$

More basically, allowing extraterritorial regulation of citizens to curb travel-evasion expands political heterogeneity by extending the range of permissible options available to states. It allows there to be states that fully permit a given activity, states that bar the activity only from occurring within their borders, and states that flatly prohibit their citizens from engaging in the activity. A regime in which all citizens could free themselves of their Home State's policies by traveling disallows the third option by definition. The absence of such an ption is not merely of

132 See Dan M. Kahan, Social Influence, Social Meaning, and Deterrence, 83 VA. L. REV. 349, 356-61 (1997) (examining the role of social influence on individuals' criminal decision making).

${ }^{133}$ See, e.g., AT\&T Corp. v. Iowa Utils. Bd., 525 U.S. 366, 418 (1999) ("[Local ratesetting differences] can amount to the kind of 'experimentation' long thought a strength of our federal system."); New State Ice Co. v. Liebmann, 285 U.S. 262, 311 (1932) (Brandeis, J., dissenting) ("It is one of the happy incidents of the federal system that a single courageous State may, if its citizens choose, serve as a laboratory; and try novel social and economic experiments without risk to the rest of the country."). 
theoretical significance. Adherents of certain political theories-for example, neo-Aristotelians, republicans, and communitarians-typically are concerned with their fellow citizens' character development and accordingly are interested in regulating conduct irrespective of where it occurs. ${ }^{134}$ Only the third option permits adherents of such perspectives the possibility of advancing their political goals. Without the third option, neo- Aristotelians, republicans, and communitarians would be hamstrung. ${ }^{135}$ On its face, this might be problematic to those who believe one of federalism's strengths is the diversity it allows. ${ }^{136}$

This point can be more formally developed by drawing upon John Rawls' influential works on liberalism. From a Rawlsian perspective, a federal system in which states may extraterritorially regulate their traveling citizens is the fair and just political structure. ${ }^{137}$ Rawls seeks to construct a just society by imagining the political institutions that people in an "original position" would choose. ${ }^{138}$ In the original position, people are under a "veil of ignorance," meaning that they do not know the religious, philosophical, or moral convictions of the people they represent. ${ }^{139}$ People in the original position accordingly would choose a basic political structure that accommodates a broad range of lifestyle choices because they would refuse to create a polity that would not accommodate the needs of the person they ended up representing. In the words of Rawls:

[T] he parties do not know whether the beliefs espoused by the persons they represent [are] a majority or a minority view. They cannot take chances by permitting a lesser liberty of conscience to minority religions, say, on the possibility that those they represent espouse a majority or dominant religion and will therefore have an even greater liberty. For it may also happen that these persons belong to a minority faith and may suffer accordingly. If the

\footnotetext{
134 See supra text accompanying notes 109-14 (explicating the philosophical foundation for the Aristotelian, communitarian, and republican position that state regulatory interests are not contingent upon location).

135 Professor Kreimer argues to the contrary that permitting extraterritorial regulation mutes diversity. See Kreimer, Whoever Treasures Freedom, supra note 49, at 915-16 (arguing that if the only way dissenters can "escape the force of a state law is to move to another state," the result would be "increas[ed] moral homogeneity"). I disagree, and I explain why infra notes 256-62 and accompanying text.

136 See, e.g., Martha Minow, Putting Up and Putting Down: Tolerance Reconsidered, in Comparative Constitutional Federalism 77, 78 (Mark Tushnet ed., 1990) (discussing the connection between federalism and diversity).

137 For an explanation as to why Rawls's views are relevant to this type of inquiry, see Rosen, Outer Limits, supra note 109, at 1061-63.

138 See RAWLS, supra note 114, at 26 ("The idea is to use the original position to model both freedom and equality and restrictions on reasons in such a way that it becomes perfectly evident which agreement would be made by the parties as citizens' representatives.”).

139 Id. at 24 n. 27.
} 
parties were to gamble in this way, they would show that they did not take the religious, philosophical, or moral convictions of persons seriously, and, in effect, did not know what a religious, philosophical, or moral conviction was.

The original position is a heuristic tool for enabling a person to imagine the political structure that is fairest from the perspective of all of society's citizens. Stated differently, the veil of ignorance and the original position transform personal self-interest into society-wide interest: People in the original position presumably will choose to $x$ commodate everybody in a fair way because they do not know whom they actually represent and accordingly would not want to create a political structure that did not accommodate whoever it is they happened to be. ${ }^{141}$

Rawls argues that the original position leads to two principles of justice that, in turn, inform the basic political structure of the just polity. ${ }^{142}$ The first principle of justice contemplates certain "basic liberties"-such as "freedom of thought and liberty of conscience" - that the polity would be required to respect. ${ }^{143}$ Rawlsians typically understand the first principle of justice as creating substantive limits to the government's regulatory powers that roughly correspond to the substantive limits of the Bill of Rights. ${ }^{144}$

But what about those activities that are not so protected but that polities are free to flatly proscribe, such as gambling? Analyzed from the perspective of the original position, the just and fair basic political structure would be a federal system in which each state would have the option of extraterritorially regulating its traveling citizens. Not permitting such extraterritorial regulation would limit the powers of subfederal polities such that they would be unable to do what many-such as Aristotelians, republicans, and communitarians, among others - think is absolutely necessary for a polity to do. People in the original position, not knowing whom they represent, would be unwilling to create such a political system where, if they happened to be an Aristotelian (for example) they would be

140 Id. at 311 (emphasis added).

141 Mark D. Rosen, "Illiberal" Societal Cultures, Liberalism, and American Constitutionalism, 12 J. CONTEMP. LEGAL ISSUES (forthcoming Winter 2002) (manuscript at 9, on file with author) [hereinafter Rosen, "Illiberal" Societal Cultures].

142 RAWLS, supra note 114, at 291-99.

$143 \mathrm{Id}$. at 281. The second principle of justice, which will not receive any attention here, concerns economic rights. Id.

144 I have argued that the first principle of justice also can be understood as requiring certain governmental regulations in select subfederal polities on behalf of certain "political perfectionists," that is, those who believe that people's moral powers can only be shaped appropriately with the polity's active intervention. Rosen, Outer Limits, supra note 109, at 1092. 
deeply dissatisfied. ${ }^{145}$ More precisely, because Aristotelians believe that polities play a necessary role in the habituation of people to act virtuously, ${ }^{146}$ they may well believe that the wrongly structured political system would be an obstacle to their fully realizing themselves as human beings. Given a choice between a political structure that would not accommodate them if they happened to be Aristotelians (or republicans or communitarians) and a political structure that could accommodate them regardless of whether they were traditional liberals or adherents of any of these other political philosophies, ${ }^{147}$ people in the original position would opt for a political structure that was more broadly accommodating, provided that people had a right to exit whichever polity they lived in and move elsewhere. Without an exit option, people who are liberals but who happened to be in a communitarian state would be trapped in a polity not suited to them. ${ }^{148}$ Failing to provide the option of extraterritorial regulation to curtail travel-evasion, however, "would show that [persons in the original position] did not take the religious, philosophical, or moral convictions of persons seriously, and, in effect, did not know what a religious, philosophical, or moral conviction was, ${ }^{, 49}$ for it would generate a political system that could not accommodate Aristotelians, republicans, and communitarians.

To conclude, because Aristotelians (as well as republicans and communitarians) require a political structure that allows extraterritorial regulation of citizens, people in the original position, not knowing whether they represented a neo-Aristotelian or a liberal, would opt for a political structure that permitted the extraterritorial regulation of citizens. That accordingly is the just and fair system. Should the person behind the veil of ignorance be a traditional liberal, she could live in a subfederal polity that did not extraterritorially regulate. Should she be a neo-Aristotelian, she

145 For an explanation as to why Rawls's threshold definition of the "political conception of the person" should not exclude Aristotelians, communitarians, or republicans, see id. at $1120-22$.

146 ARistotle, Nicomachean Ethics 1098a15, 1103b1-1103b5 (Terence Irwin trans., 1985).

147 This is not to suggest that they would elect to create a political structure that accommodated all possible political theories. For a discussion of those which would not be accommodated, see Rosen, Outer Limits, supra 109, at 1068-71.

${ }^{148}$ For more on exit, see id. at 1097-106. The constraint of "well-orderedness" presumably would not be implicated insofar as state policies still would be limited by constitutional limitations. See id. at 1093-97 (arguing that the "well-ordered society" requirement entails substantive limitations on subfederal sovereigns, which deny such specific powers as making treaties with foreign nations and constrain other activities that have significant effects outside of the community).

${ }^{149}$ RAWLS, supra note 114 , at 311. 
could live in a polity that did so regulate. For these reasons, permitting a state to regulate its citizens' out-of-state activities is not fundamentally unfair for purposes of due process. ${ }^{150}$ To the contrary, permitting such extraterritorial regulation is normatively desirable from a Rawlsian perspective, and a political structure that flatly proscribed states from extraterritorially regulating to curb travel-evasion would be unjust.

\section{Bigelow v. Virginia and Extraterritoriality}

In the 1975 case of Bigelow v. Virginia, ${ }^{151}$ the Supreme Court made some observations that Professor Seth Kreimer has construed as disallowing states from criminalizing their citizens' out-of-state conduct. ${ }^{152}$ Professor Donald Regan has come to a different conclusion, arguing that the principles of extraterritoriality enunciated in cases such as Skiriotes and Strassheim remain good law and that any anti-extraterritoriality statements in Bigelow are mere obiter dicta. Professors Kreimer and Regan have closely analyzed one section of the Bigelow opinion that touched on extraterritoriality, and a careful review strongly supports Professor Regan's conclusion that it is dictum. ${ }^{153}$ There is a second point in Bigelow, not discussed by the two scholars, in which the Court asserts an even more forceful anti-extraterritoriality statement. This too is best understood as dictum. Furthermore, subsequent caselaw has narrowed Bigelow such that what remains of any extraterritoriality principle it may have articulated would have no bearing on the types of extraterritoriality that are the subject of this Article.

The Virginia statute at issue in Bigelow prohibited the sale or

${ }^{150}$ Professor Kreimer surveys a number of potential justifications for a state's extraterritorial regulation of its citizens and finds them all to be lacking. See Kreimer, Whoever Treasures Freedom, supra note 49, at 924-38 (exploring possible justifications for a citizen's obligation to obey extraterritorial state laws, i.e., consent, fairness, and the necessity of order). He does not consider the arguments made above, however, and common sense suggests that even one legitimate justification would suffice to take extraterritoriality out of the cat egory of fundamentally unfair.

151421 U.S. 809 (1975).

152 See Kreimer, Law of Choice, supra note 5, at 462 (arguing that Bigelow establishes the principle that states cannot "punish their citizens for conduct that is protect ed in the sister state where it occurs"). Professor Lea Brilmayer at one point suggested that Bigelow "casts some doubt on a state's authority to regulate the activities of residents while in other states," LEA BRILMAYER ET AL., AN INTRODUCTION TO JURISDICTION IN THE AMERICAN FEDERAL SYSTEM 327 (1986), but she appears to have backed off from this view in a more recent work, see Lea Brilmayer \& Charles Norchi, Federal Extraterritoriality and Fifth Amendment Due Process, 105 HARV. L. RE V. 1217, 1241 (1992) ("It is also fairly well established that a state may regulate its residents, even when they are acting outside the state.”).

${ }^{153}$ See Appendix: Analysis of the Kreimer/Regan Debate Concerning Bigelow. 
circulation of any publication that encouraged or prompted the procuring of an abortion. The editor of a Virginia newspaper was convicted for violating the statute because the paper had printed an advertisement for low-cost abortion services in New York that had been placed by a for-profit abortion referral service. The Court ruled that such an pplication of the statute violated the First Amendment.

The relevant passage from the opinion that Professors Kreimer and Regan have considered states that Virginia could not "prevent its residents from traveling to New York to obtain those services or, as the State conceded, prosecute them for going there. Virginia possessed no authority to regulate the services provided in New York ...."154 The section of the opinion in which this assertion appears concerned the question of whether commercial advertisements should receive First Amendment protection. The quoted language constitutes dictum for the reasons explained in this Article's Appendix.

Consider next the extraterritoriality discussion in Bigelow that was not discussed by Professors Kreimer and Regan. After establishing that the advertising received First Amendment protection, the Court applied the then-applicable constitutional test ${ }^{155}$-a balancing of interests-and concluded that the Virginia statute infringed upon the editor's First Amendment rights. At this point in the decision, in relation to assessing the quantum of Virginia's governmental interest, the Court once again discussed extraterritoriality. The Court stated:

To be sure, the agency-advertiser's practices, although not then illegal, may later have proved to be at least "inimical to the public interest" in New York. But [a] this development would not justify a Virginia statute that forbids Virginians from using in New York the then legal services of a local New York agency. Here, Virginia is really asserting an interest in regulating what Virginians may hear or read about the New York services. It is, in effect, advancing an interest in shielding its citizens from information about [b] activities outside Virginia's border, activities that Virginia's police powers do not reach. This asserted interest, even if understandable, was entitled to little, if any, weight under the circumstances. ${ }^{156}$

This discussion, which assesses the extent of the government's interest, is essential to the Court's ultimate holding that the Virginia statute violated the editor's rights under a balancing of interests. What, if any, of it

154 Bigelow, 421 U.S. at 824 (citations omitted).

155 The Court has since adopted a four-part test that governs First Amendment challenges to commercial speech. See Cent. Hudson Gas \& Elec. Corp. v. Pub. Serv. Comm'n, 447 U.S. 557, 566 (1980) (applying the four-step analysis to a ban on promotional advertising).

156 Bigelow, 421 U.S. at 827 (emphasis added) (citations omitted). 
constitutes a holding, however, is difficult to say. Dicta, of course, typically refers to statements in opinions that are not necessary to support the Court's outcome. ${ }^{157}$ Neither statement [a] nor statement [b] were necessary to the Court's ultimate conclusion that the government's interest is outweighed by the individual's interest in having access to information concerning services available out of state. This can be seen by noting that the principle that a state may regulate its citizens' out-of-state activities is not incompatible with the principle that a state may not control its citizens' knowledge of what activities are permissible in other states. The latter principle may well interfere with the preconditions to a meaningful exercise of the citizens' right to travel (the decision to remain where she lives or instead to relocate to a new jurisdiction), whereas extraterritorial regulation does not. ${ }^{158}$ The Bigelow Court consequently did not have to decide any larger extraterritoriality principles in coming to its conclusion that Virginia's statute violated the First Amendment, rendering the Court's extraterritoriality observations mere dicta.

Furthermore, understanding statements [a] and [b] as dicta is consistent with the canonical distinction between dicta and holding. As explained by Chief Justice Marshall in Cohens $v$. Virginia,${ }^{159}$ dicta is afforded less weight than holdings because only " $[t]$ he question actually before the court is investigated with care, and considered in its full extent. Other principles which may serve to illustrate it, are considered in their relation to the case decided, but their possible bearing on all other cases is seldom completely investigated." 160

Consistent with this understanding of dicta, the Bigelow Court did not give careful consideration to the extent of a state's extraterritorial powers. Nowhere in the opinion did the Bigelow Court discuss the caselaw (such as Strassheim and Skiriotes) with which its anti-extraterritorial position was inconsistent. Further, although the Court did cite three cases to support the anti-extraterritorial proposition (cases that were the subject of Professor Kreimer and Professor Regan's dispute), Professor Regan's conclusion that "none of the three cases is apposite" is unimpeachable:

United States v. Guest stands for the proposition that there is a right of interstate movement which is constitutionally protected against private

157 Michael C. Dorf, Dicta and Article III, 142 U. PA. L. REV. 1997, 2000 (1994). Dorf ultimately criticizes this generally accepted understanding of dicta and offers an alternative. See id. at 2040-42 (illustrating the difficulty of ascertaining the scope of judicial decisions).

158 See infra Part II.B (describing the modest limitations that the right to travel imposes on Home States' powers to regulate).

159 19 U.S. 120,6 Wheat. 264 (1821).

160 Id. at $399-400$. 
interference. Shapiro v. Thompson is about a right of interstate migration, which involves precisely changing one's state citizenship. Doe v. Bolton involves the article IV privileges and immunities clause, and establishes that New York (Georgia, in the original) cannot deny nonresidents acess to abortion referral services (abortion services, in the original) operating in New York. This is obviously a quite different issue from whether Virginia can deny its own citizens access to services in New York. ${ }^{161}$

All that needs to be added is that Professor Regan's analysis is undisturbed by the Court's most recent pronouncement concerning the right to travel in Saenz v. Roe, ${ }^{162}$ which explained the cases analyzed by Professor Regan in terms virtually identical to his own. ${ }^{163}$ In short, Bigelow's observations concerning extraterritoriality are comfortably characterized as dicta because they were not necessary to the Court's holding, they were unsupported by the cases to which they made an oblique reference, and they did not take account of the caselaw with which they were at odds.

In any event, Bigelow has been significantly modified by subsequent cases. The Supreme Court held in United States v. Edge Broadcasting $\mathrm{Co}^{164}$ that nonlottery states have a legitimate interest in shielding their citizens from advertisements for lotteries in states in which lotteries are legal. ${ }^{165}$ The Court understood that North Carolina's antigambling policy would have been undermined had a North Carolina broadcaster been permitted to broadcast advertisements for an activity that was legal in another state but prohibited in North Carolina. The parallels between the statutes at issue in Edge and Bigelow were thus quite striking: in both cases, the statutes prevented in-state informational media from broadcasting outof-state advertisements of activities legal out of state, but not at home. Unlike Bigelow, however, the Edge Court upheld the statute at issue against a First Amendment challenge. ${ }^{166}$ To be sure, Edge does not flatly overrule Bigelow, since the statute upheld in Edge was federal rather than state.

161 Regan, supra note 27, at 1907 (citations omitted).

162526 U.S. 489, 500-02 (1999). The Saenz decision did not deal with limitations on a state's power to regulate its citizens' out-of-state activities, but concerned limits on a state's powers to discriminate between old-time residents and newcomers.

163 See id. at 498, 500-02 (citing United States v. Guest, 383 U.S. 745 (1966), for the proposition that the constitutional right to travel from one state to another, though not in the text of the Constitution, is firmly embedded in the Court's jurisprudence; emphasizing that the holding in Shapiro v. Thompson, 394 U.S. 618 (1969), focused on the right to interstate migration; and explaining that Doe v. Bolton, 410 U.S. 179 (1973), concerns nonresidents who enter a state for the procurement of medical services).

164509 U.S. 418 (1993).

165 See supra notes 103-08 and accompanying text (discussing the Court's analysis in Edge).

66509 U.S. at 426-36. 
Nonetheless the Edge case undercuts Bigelow's flat assertion that one state's police powers do not extend into another state; if states have a legitimate interest in their citizens' out-of-state conduct, as Edge holds, then why do their police powers categorically end at their borders? Edge's holding surely is more consonant with cases such as Strassheim and Skiriotes, which upheld the out-of-state exercise of police power because a state's legitimate interests can be implicated by out-of-state activities. ${ }^{167}$

Furthermore, the holding in Bigelow was expressly limited in Posadas de Puerto Rico Associates v. Tourism Co. of Puerto Rico. ${ }^{168}$ The Court in Posadas held that Puerto Rico could prohibit Puerto Rican gambling establishments, which had been established to cater to travelers, from advertising to Puerto Rican residents. ${ }^{169}$ In so holding, the Court had to explain its holding in Bigelow. The Posadas Court could have distinguished Bigelow on the ground that Bigelow concerned extraterritoriality, but the Posadas Court did not do so. Instead, the Posadas Court explained that the advertising restrictions in Bigelow were problematic only because the "underlying conduct that was the subject of the advertising restrictions [abortion] was constitutionally protected and could not have been prohibited by the State. Here, on the other hand, the Puerto Rico Legislature surely could have prohibited casino gambling by the residents of Puerto Rico altogether." 170 Thus, even if (contrary to the conclusion above) Bigelow's anti-extraterritorial discussions constituted a holding, Posadas would appear to provide an important caveat: Bigelow's assertion that Virginia's interest was entitled to little, if any, weight because its "police powers do not reach" activities outside of Virginia's borders ${ }^{171}$ must be understood after Posadas to mean that the Home State's police powers do not extend to the extraterritorial regulation of matters that the Constitution prohibits Home States from banning. ${ }^{172}$ Any such limitation on extraterritoriality is

167 See supra Part I.A (reviewing early Supreme Court caselaw to confirm the proposition that Home States have the power to regulate their citizens' extraterritorial conduct)

168478 U.S. 328 (1986).

169 Id. at $340-44$.

170 Id. at $345-46$.

171 Bigelow v. Virginia, 421 U.S. 809, 828 (1975).

172 Rather than limiting Bigelow, it could be argued that Posadas merely explained limiting language that already appeared in Bigelow itself. The Bigelow opinion stated that Virginia "is, in effect, advancing an interest in shielding its citizens from information about activities outside Virginia's borders, activities that Virginia's police powers do not reach. This asserted interest, even if understandable, was entitled to little, if any, weight under the circumstances." Id. (emphasis added). In other words, "the circumstances" under which Virginia had no interest in regulating the extraterritorial conduct of its citizens were when the underlying conduct was constitutionally protected. In any event, it makes no difference to the 
immaterial to the regulations that are the subject of this Article, namely, laws that regulate activities that are not constitutionally protected, such as gambling, riding a motorcycle without a helmet, and the like. ${ }^{173}$

To quickly summarize, consistent with the teachings of the Model Penal Code and the Restatement (Third) of Foreign Relations, Home States indeed have a presumptive power to regulate their citizens' out-of-state activities to avoid travelevasion. Such extraterritorial powers are wholly consistent with contemporary due process doctrine; states have special interests both in the welfare of their citizens and in ensuring that legitimate state policies not be thwarted through the expedient of travel. Such powers are consonant with longstanding Supreme Court caselaw, and they have not been undermined by the case of Bigelow v. Virginia or any Supreme Court decision since.

\section{Federalism’s Putative Broad-Based Limits on Home States}

As several commentators have correctly noted, the Constitution imposes, aside from due process-related concerns, limits on Home States' ability to regulate the out-of-state conduct of their citizens. The scope of these limitations, however, has been overstated in the literature. Examined in this Part are the Privileges and Immunities Clause of Article IV, the right to travel, the Dormant Commerce Clause, and various "structural" constitutional considerations. Properly understood, these constitutional limits on Home States' extraterritorial powers are only modest; they leave ample room for a Home State to regulate its citizens' out-of-state activities. ${ }^{174}$

\section{A. Privileges and Immunities Clause}

The Privileges and Immunities Clause of Article IV provides that "[t]he citizens of each State shall be entitled to all Privileges and Immunities of Citizens in the several States." ${ }^{, 175}$ Professor Kreimer has suggested that this

types of extraterritoriality discussed in this Article whether Posadas is understood as limiting or merely clarifying Bigelow.

173 This is true even with respect to parental notification laws, for states are free to condition a minor's abortion on parental notification and consent. See Planned Parenthood v. Casey, 505 U.S. 833, 899-900 (1992) (holding that the parental consent requirement of the Pennsylvania Abortion Control Act of 1992 did not violate the Constitution). The underlying activity in Bigelow, by contrast, was an adult's obtaining of an abortion, for which there is a clear constitutional right under Roe v. Wade, 410 U.S. 113 (1973).

174 Part III will explain more fully why states' extraterritorial powers over their citizens does not lead to anarchy that would undermine our nation's federal system.

${ }^{175}$ U.S. CONST. art. IV, § 2, cl. 1. 
clause flatly precludes the Home State from regulating its citizens' conduct in sister states. ${ }^{176}$ According to Professor Kreimer:

$[\mathrm{H}]$ ome States cannot waive the Article IV rights of their citizens when the states regard those rights as unnecessary to guard against interstate friction; rather, the citizens as individuals are "entitled" to local privileges and immunities when they visit neighboring states. As citizens from different states travel and interact on a basis of equality, they develop and maintain consciousness of themselves as equals and members of a single polity.

This argument falls short on several grounds. To begin, no claim based on the Privileges and Immunities Clause can serve as a general argument against Home State regulation of its citizens' out-of-state conduct because the clause properly applies to only a limited category of regulations, as demonstrated below in Subsection 1. Furthermore, the argument put forward by Professor Kreimer is inconsistent with longstanding privileges and immunities caselaw. As discussed below in Subsection 2, wellestablished caselaw provides that the Privileges and Immunities Clause does not apply to a State's regulation of its own citizens, but rather applies to the regulation of states' relationships with visitors who are citizens of other states; in the lingo of this Article, the clause addresses Host States, not Home States. Even so, the clause could indirectly interfere with the Home State's effort to regulate its citizens' out-of-state conduct if it were construed as compelling the Host State to apply its laws to the visitor irrespective of the Home State's policy. Subsection 3 shows that the Privileges and Immunities Clause compels no such result. The clause does not bar a Host State from applying the Home State's laws to visitors if there are good reasons to do so and applying another state's laws to traveling citizens of that state for the purpose of maintaining the legitimate policies of the Home State should satisfy this standard. Finally, Subsection 4 will

176 Kreimer, Whoever Treasures Freedom, supra note 49, at 917-21.

177 Id. at 918-19 (emphasis added) (footnote omitted). That Professor Kreimer interprets the clause's entitlement as extending broadly to cover virtually all laws is strongly suggested by the sentences that follow those quoted above in the text:

By contrast, a system in which my opportunities upon entering California remain subject to the moral demands of Pennsylvania undercuts this sense of national unity. Such a system would deny to me, because of my status as Pennsylvanian, the privileges that the Californians I pass on the street share as their birthright. This situation hardly advances the goal of establishing a single national identity.

$I d$. at 919. Such a goal of national unity would appear to require that one's Home State identity not diminish the opportunities that a Pennsylvanian visiting California has vis-à-vis Californians in all respects. See also Kreimer, Law of Choice, supra note 5, at 463 (advancing a similar argument based on the Privileges and Immunities Clause, a provision which, Kreimer argues, embodies the "constitutional commitments to national union and national citizenship"). 
explain why the doctrinal status quo described in Subsections 1 through 3 is normatively desirable.

\section{The Limited Activities that Constitute "Privileges" or "Immunities"}

It is important to understand what is and what is not at stake under Article IV's Privileges and Immunities Clause. The clause provides protection only to "privileges" and "immunities" and therefore could not be the source of an across-the-board prohibition against a Home State's regulation of its citizens' out-of-state conduct. ${ }^{178}$ The Supreme Court has defined privileges and immunities so that they encompass only "such basic and essential activities, interference with which would frustrate the purposes of the formation of the Union." 179 This has been held to include only a limited number of things, including "the pursuit of common callings, the ability to transfer property, . . . access to courts" ${ }^{\prime 180}$ and the right of nonresidents to settle in a new state. ${ }^{181}$ For example, the Court has held that "[e]quality in access to Montana elk is not basic to the maintenance or wellbeing of the Union," in upholding a statutory elk-hunting license scheme that imposed substantially higher license fees on nonresidents than residents. $^{182}$

\footnotetext{
178 Professor Kreimer's position on the question of what activities fall within the purview of the Privileges and Immunities Clause is unclear. On the one hand, the logic of his analysis of the clause suggests the position that visitors from sister states should be subject to all of the Host State's laws. See supra note 177 and accompanying text (discussing Kreimer's suggestion that the Privileges and Immunities Clause flatly precludes the Home State from regulating its citizens' conduct in sister states). Furthermore, much of his argument takes the form of positive analysis. See, e.g., Kreimer, Whoever Treasures Freedom, supra note 49, at 918 (citing Toomer v. Witsell, 334 U.S. 385 (1948), for the proposition that the Privileges and Immunities Clause imposes limitations on the Home States). For my critique of Professor Kreimer's interpretation of Toomer, see infra notes 197-204 and accompanying text. For a clear description of the distinctions among positive, prescriptive, and normative analyses, see generally Christine Jolls et al., A Behavioral Approach to Law and Economics, 50 STAN. L. REV. 1471, 1474-75 (1998).

On the other hand, Professor Kreimer refers in a footnote to cases that have found certain matters to be outside the scope of a protected "privilege" or "immunity." Kreimer, Law of Choice, supra note 5, at 499 n.167. Perhaps his argument, which gives rise to a very broad scope of "privileges and immunities," is intended to be a prescriptive rather than a positive analysis. If that is so, then the crux of my response is not found in Subsections 1 through 3, which is primarily an analysis of the contemporary doctrine, but instead appears in Part II.A.4, which explains why the doctrinal status quo is wise as a normative matter. Subsections 1 through 3 are still important, however, insofar as it is critical to have a clear understanding of the current law regardless of whether one is defending or criticizing it.

179 Baldwin v. Fish \& Game Comm'n, 436 U.S. 371, 387 (1978).

180 Id.

181 Zobel v. Williams, 457 U.S. 55, 76 (1982) (O’Connor, J., concurring).

182 Baldwin, 436 U.S. at 388.
} 
In short, the terms "privileges" and "immunities" do not embrace a general right of visitors to be treated as in-staters, but instead have a more limited meaning. Many "distinctions between residents and nonresidents merely reflect the fact that this is a Nation composed of individual States," and it is "[o]nly with respect to those 'privileges' and 'immunities' bearing upon the vitality of the Nation as a single entity [that the state must] treat all citizens, resident and nonresident, equally." 183

None of the peripatetic citizens' activities discussed in this Article would appear to constitute a "privilege" or "immunity" for purposes of Article IV. This can be illustrated by considering what might be the most controversial of the extraterritorial limitations considered in this Article; that is, a regulation barring a state's citizens from circumventing its Home State's parental notification laws by traveling to a jurisdiction that is without such a requirement. Obtaining an abortion without parental notification plainly does not fall into any of the aforementioned protected activities. Furthermore, given the fact that parental notification statutes are constitutional, it would be difficult to argue that an activity that cannot be legally undertaken at home becomes part of the class of "such basic and essential activities, interference with which would frustrate the purposes of the formation of the Union" ${ }^{\text {"184 }}$ when the ban is extended out of state. ${ }^{185}$ Nonetheless, because it is conceivable that a Home State might wish to regulate a protected "privilege" or "immunity," 186 it is necessary to examine more fully Professor Kreimer's argument.

\section{Inapplicability to the Home State}

The Privileges and Immunities Clause has long been understood as having created limitations on Host States with respect to citizens visiting from other states, but at no point has it been understood to limit a state's regulatory powers over its own citizens. This is because the clause consistently has been understood as being directed toward eliminating “"discriminating legislation against [visiting citizens] by other States.",187 The "disabilities of alienage in other States" "188 that the clause proscribes

183 Id. at 383.

184 Id. at 387.

185 The only plausible argument to this effect would be parasitic on the right to travel, which I discuss infra Part II.B.

${ }^{186}$ For example, an antigambling state may wish to prevent its citizens from working in gambling establishments located in states in which gambling is le gal.

187 Baldwin, 436 U.S. at 380 (quoting Paul v. Virginia, 75 U.S. (8 Wall.) 168, 180 (1869)).

188 Id. 
are, by their nature, regulations that emanate from Host States rather than Home States. Thus, in the 1872 case of Bradwell v. Illinois, the Court rejected a privileges and immunities claim asserted by an Illinois woman who challenged an Illinois law that barred women admission to the $\operatorname{bar}^{189}$ on the ground that the clause does not constrain Home States:

As regards the provision of the Constitution that citizens of each State shall be entitled to all the privileges and immunities of citizens in the several States, the plaintiff in her affidavit has stated very clearly a case to which it is inapplicable. The protection designed by that clause, as has been repeatedly held, has no application to a citizen of the State whose laws are complained of. If the plaintiff was a citizen of the State of Illinois, that provision of the Constitution gave her no protection against its courts or its legislation. ${ }^{190}$

The Court in the Slaughter-House Cases restated this understanding, observing that the Privileges and Immunities Clause of Article IV "does not profess to control the power of the State governments over the rights of its own citizens." ${ }^{\prime 191}$ Fully consistent with this observation, the Court in United States $v$. Wheeler noted in passing that the Privileges and Immunities Clause provides that "one State should not deny to the citizens of other States rights given to its own citizens.", 192 And more recently, the Supreme Court confirmed this understanding of the Privileges and Immunities Clause in the 1984 case of United Building \& Construction Trades Council v. Mayor of Camden, ${ }^{193}$ noting that although out-of-state citizens could pursue a privileges and immunities claim against the New Jersey municipality of Camden, "disadvantaged New Jersey residents have no claim under the Privileges and Immunities Clause." 194 As the Court explained, "New Jersey residents at least have a chance to remedy at the polls any discrimination against them. Out-of-state citizens have no similar opportunity . .."195 In other words, the clause limits Host States, but not Home States.

Professor Kreimer, however, asserts the converse proposition that the

18983 U.S. (16 Wall.) 130, 138 (1872).

190 Id.

191 See 83 U.S. (16 Wall.) 36, $75-77$ (1873) (construing Article IV's Privileges and Immunities Clause to aid in interpreting the Fourteenth Amendment's Privileges and Immunities Clause).

192254 U.S. 281, 298 (1920); see also Blake v. McClung, 172 U.S. 239, 252 (1898) (reasserting the validity of a narrow interpretation of the Privileges and Immunities Clause).

193465 U.S. 208 (1984).

194 Id. at 217 (citing The Slaughter-House Cases, 83 U.S. (16 Wall.) at 77).

195 Id. For the canonical discussion of the logic behind this approach to constitutional interpretation, what is now often spoken of as a "representation-reinforcing" method, see JOHN HART Ely, DEMOCRACY AND DISTRUST: A THEORY OF JUdICIAL REVIEW (1980). 
Privileges and Immunities Clause applies to Home States as well. ${ }^{196}$ To support his claim, Kreimer quotes language from the 1948 case of Toomer $v$. Witsell, ${ }^{197}$ stating that the clause "was designed to insure to a citizen of State $A$ who ventures into State $B$ the same privileges which the citizens of State $B$ enjoy." 198 While it is true that this phrase is ambiguous, and on its own could be read to create a limitation on the Home State as well as the Host State, the holding in Toomer struck down a Host State's statute, not a Home State's law. Moreover, other language in the opinion undermines Professor Kreimer's interpretation of the phrase. ${ }^{199}$ More importantly, there are far more recent cases than Toomer where the Court has confirmed the traditional view that the Privileges and Immunities Clause does not impose limitations on the Home State. The aforementioned case of Camden is one. ${ }^{200}$ Another is the 1982 case of Zobel v. Williams, ${ }^{201}$ where the Court also concluded that the clause was inapplicable to a claim asserted by a citizen against her Home State. At issue in Zobel was the constitutionality of an Alaska statute that awarded distributions from the state's mineral

\footnotetext{
196 See Kreimer, Whoever Treasures Freedom, supra note 49, at 913, 917-21 (arguing that the Privileges and Immunities Clause mandates "a territorial onception of state regulatory authority over state citizens' activities in sister states").

197334 U.S. 385 (1948).

198 Kreimer, Whoever Treasures Freedom, supra note 49, at 918 (referencing Toomer, 334 U.S. at 395)

${ }_{199}$ Thus, even if Professor Kreimer's interpretation were correct, the Toomer language would be mere dicta. In any event, a close reading of the opinion strongly suggests that the Toomer Court's language is best understood as applying only to Host States. The sentence following the one that Professor Kreimer quotes makes the most sense if understood to speak only of the State $A$ citizen's right not to be treated differently by Host State $B$ because she is not a citizen of State $B$. That next sentence states that "[f]or protection of such equality the citizen of State $A$ was not to be restricted to the uncertain remedies afforded by diplomatic processes and official retaliation." Toomer, 334 U.S. at 395 . If the Home State were the source of disparate treatment, the Court would have been suggesting that the citizen of State $A$ might attempt to get her Home State to act differently by using the "diplomatic processes" of the Host State. This would be strange for two reasons. First, noncitizens typically are not beneficiaries of diplomatic processes. Second, the more direct way for a citizen to effectuate change would be to lobby the representatives of her Home State, and one would have expected the Court to have mentioned this as a possible route to addressing her dissatisfactions. Further support for the conclusion that the Toomer case is not making any radical doctrinal expansions is the Court's explanation one sentence later that the clause was designed to "remov[e] from the citizens of each State the disabilities of alienage in the other States." Id. at 396 (quoting Paul v. Virginia, 75 U.S. (8 Wall.) 168, 180 (1868)). "Disabilities of alienage" likely refers to disparate treatment at the beckoning of the Host State, the state that typically is the source of such disparate treatment.

200 See supra notes 193-95 and accompanying text (noting that the Camden Court recognized no cause of action under the Privileges and Immunities Clause against the Home State and emphasizing the availability of a political remedy in the Home State which did not exist in the Host State)

201457 U.S. 55 (1982).
} 
income to its citizens but adjusted the size of compensation on the basis of how long the citizen had been a resident of Alaska. Said the majority:

The Alaska statute does not simply make distinctions between native-born Alaskans and those who migrate to Alaska from other states . . . The Alaska statute also discriminates among long-time residents and even native-born residents....

The statute does not involve the kind of discrimination which the Privileges and Immunities Clause of Art. IV was designed to prevent. That Clause "was designed to insure to a citizen of State A who ventures into State B the same privileges which the citizens of State B enjoy." The Clause is thus not applicable to this case. ${ }^{2}$

The Privileges and Immunities Clause would have applied if Toomer actually meant what Professor Kreimer suggests it does. Thus, in addition to constituting a holding, ${ }^{203}$ Zobel confirms the understanding that Toomer did not announce an expanded doctrine of privileges and immunities that extends to Home States. ${ }^{204}$ In short, there has been no break in the long-

202 Id. at 59-60 n.5 (quoting Toomer, 334 U.S. at 395).

203 Professor Kreimer is mistaken when he asserts that only in one case-the Bradwell decision discussed above-was the clause's inapplicability to Home States the grounds for the Court's decision. See Kreimer, Law of Choice, supra note 5, at 512-13. Zobel and Camden also held the clause inapplicable to Home States.

204 To be sure, Professor Kreimer does not overlook the Zobel case. His use of the case, however, is dubious. He suggests on the basis of Zobel that "Justice O'Connor-joined on occasion by both Justices Brennan and Rehnquist-has manifested skepticism" regarding the principle announced in the Slaughter-House Cases that the Privileges and Immunities Clause " "does not profess to control the power of State governments over the rights of its own citizens."” Id. at 512-13 (quoting The Slaughter-House Cases, 83 U.S. (16 Wall.) 36, 77 (1873)).

However, a close look at Justice O'Connor's concurrence does not suggest that she doubts the Slaughter-House principle, but instead that she holds the traditional view that the clause only regulates states' relationships with noncitizens. According to Justice O'Connor, the statute at issue in Zobel had an impact on interstate migration insofar as it awarded smaller distributions of the state's mineral income to recent immigrants than to long-term residents. By making it less attractive for newcomers, the statute implicated the "right to establish residence in a new State.” Zobel, 457 U.S. at 77 (O'Connor, J., dissenting). Justice O'Connor specifically refused to characterize the case as "discriminat[ing] among classes of residents, rather than between residents and nonresidents" and instead noted that the statute "classifie[d] citizens on the basis of their former residential status." Id. at 75 . While it was true that the Alaska statute applied to persons who technically already had become residents of Alaska, " $[t]$ he fact that this discrimination unfolds after the nonresident establishes residency does not insulate Alaska's scheme from scrutiny under the Privileges and Immunities Clause." Id. Justice O'Connor deployed Toomer's doctrinal statement that the clause "was designed to insure to a citizen of State A who ventures into State B the same privileges which the citizens of State B enjoy" and then explained that "the citizen of State A who ventures into [Alaska] to establish a home labors under a continuous disability." Zobel, 457 U.S. at 74-75 (alteration in original) (internal quotation marks omitted).

In short, Justice O'Connor's analysis-which, in any event, has never commanded a 
standing doctrine that the Privileges and Immunities Clause does not constrain Home States.

\section{Obligations Imposed on the Host State}

Even if this reading of the Privileges and Immunities Clause does not limit the power of Home States to regulate their citizens' out-of-state activities, virtually identical constraints on Home States would obtain if the clause were construed to require the Host State to apply its laws to visitors from other states irrespective of the Home States' policy. ${ }^{205}$ Professor Kreimer appears to propound such an interpretation of the clause when he cites the case of Austin v. New Hampshire ${ }^{206}$ for the proposition that "the status of the $[\mathrm{H}]$ ome $[\mathrm{S}]$ tate's antiabortion policy would not dilute the entitlement of out-of-state visitors to obtain abortions on a basis of equality with domestic residents. ${ }^{, 207}$ A closer look at Austin shows that the case

majority of the Court-does not express "skepticism" concerning the Slaughter-House principle. Rather, it is a practical, functional analysis that refuses to allow change of residency to ipso facto terminate the clause's regulation of states' relations with noncitizens. According to Justice O'Connor, in other words, under the circumstances of a state law that affects interstate migration by treating long-term residents more favorably than those who not long ago were nonresidents, the Privileges and Immunities Clause still is applicable. Justice O'Connor's dissent in Attorney General v. Soto-Lopez, likewise concerned a statute that affected interstate migration. See 476 U.S. 898, 920 (1986) (O'Connor, J., dissenting) (arguing that New York's restriction of civil service preference to veterans who entered the armed forces while residing in New York was constitutional under intermediate scrutiny because New York legitimately may seek to reward those who represented the state while in the armed forces). Professor Kreimer has suggested that this dissent stands for the same principle he attributes to O'Connor's Zobel concurrence. Kreimer, Law of Choice, supra note 5 , at 513 n.209.

205 Although the Privileges and Immunities Clause would not bar the Home State from regulating its citizens' out-of-state activities under this approach, the Home State likely would not be able to prosecute or otherwise penalize its citizens for doing what the Constitution required them to do while they were in the Host State. In short, under this understanding of the Privileges and Immunities Clause, the Home State would be able to legislate vis-à-vis its traveling citizens, but would not be able to enforce its regulations. As a practical matter, such a constraint would be quite similar to what would obtain if the Privileges and Immunities Clause were directly applicable to Home States (the position discussed, and rejected, above in Subsection 2). Almost, but not exactly similar, for laws on the books can have real effects even if they are not enforced. See generally Christopher R. Leslie, Creating Criminals: The Injuries Inflicted by "Unenforced" Sodomy Laws, 35 HARV. C.R.-C.L. L. REV. 103 (2000) (using sodomy laws to demonstrate the harms suffered by individuals targeted by "harmless" unenforced laws).

206420 U.S. 656 (1975).

207 Kreimer, Whoever Treasures Freedom, supra note 49, at 919 n.41. Professor Kreimer argues that " $[\mathrm{H}]$ ome $[\mathrm{S}]$ tates cannot waive the Article IV rights of their citizens when the states regard those rights as unnecessary to guard against interstate friction; rather, the citizens as individuals are 'entitled' to local privileges and immunities when they visit neighboring states." $I d$. at 918-19. I think this is best understood as a claim that the 
stands for a significantly different principle. Moreover, the larger web of privileges and immunities decisions definitively shows that the clause does not create an unqualified duty for Host States to apply the same laws to visitors that are applicable to their citizens irrespective of the Home State's policy.

Austin concerned a privileges and immunities challenge to New Hampshire's income tax. New Hampshire's statute had the effect of taxing the New Hampshire income of nonresidents, but not the income of residents. However, under the terms of the statute, Host State, New Hampshire, would not tax the nonresident's New Hampshire income if the nonresident's Home State did not grant acredit for taxes paid to New Hampshire. Like every other state, the Home State of Maine gave its citizens a tax credit for income taxed by other states. Thus, Maine could have wholly eliminated the taxes its citizens had to pay on income earned in New Hampshire, thereby putting them on equal footing with New Hampshire residents, simply by terminating Maine's statutory credit for taxes paid by its citizens to New Hampshire. ${ }^{208}$

The Austin Court struck down New Hampshire's tax law under the Privileges and Immunities Clause because of the statute's inequitable "treatment for the citizens of the taxing State and nonresident taxpayers.",209 The Court concluded it was irrelevant that Maine, by repealing its tax credit, could have eliminated the differential treatment its citizens were accorded by New Hampshire because "the constitutionality of one State's statutes affecting nonresidents [cannot] depend upon the present configuration of the statutes of another State. ${ }^{, 210}$ The Austin Court supported this proposition by approvingly quoting language from the earlier case of Travis $v$. Yale \& Towne Manufacturing Co.: "“A State may not barter away the right, conferred upon its citizens by the Constitution of the United States, to enjoy the privileges and immunities of citizens when they go into other States. ${ }^{, 211}$

Professor Kreimer relies on Austin and Travis to support his claim that the status of the Home State's antiabortion policies does not affect out-ofstate visitors' rights to obtain abortions on an equal basis with domestic residents. $^{212}$ Austin and Travis, however, involve scenarios that are

Privileges and Immunities Clause imposes an obligation on the Host State that cannot be changed by the Home State. In any event, the analysis of Austin and Travis in text below would be equally applicable even if Professor Kreimer's argument were construed as another limitation on the Home State.

208 Austin, 420 U.S. at 666.

209 Id. at 665.

210 Id. at 668.

211 Id. at 667 (quoting Travis v. Yale \& Towne Mfg. Co., 252 U.S. 60, 82 (1920)).

212 Kreimer, Whoever Treasures Freedom, supra note 49, at 919 n.41. 
importantly different from Professor Kreimer's abortion example. In both Austin and Travis, the Host State was discriminating against nonresidents to advance its own interests. ${ }^{213}$ The states in each case did so via laws they enacted that expressly discriminated between residents and nonresidents. These two cases rejected the argument that self-interested discrimination could be saved from unconstitutionality by statutory provisions permitting the Home State to terminate the Host State's discrimination against the former's citizens by in turn discriminating against the Host States' citizens. Austin refused to accept the New Hampshire scheme because "New Hampshire in effect invites [the Maine appellants] to induce their representatives, if they can, to retaliate against [differential tax treatment]" by amending Maine's laws "so as to deny a credit for taxes paid to New Hampshire while retaining it for the other 48 States." 214 Travis found the New York scheme equally objectionable because it allowed New York's differential treatment of nonresidents to be undone only if other states "retaliat[ed]" with similar exemption schemes. ${ }^{215}$

Professor Kreimer's analysis thus assumes without argument that Austin and Travis's teachings are fully applicable to the altogether distinct circumstance of a Host State seeking to accommodate the Home State's interests in seeing that its citizens not engage in travel-evasion. Such an assumption is unwarranted. The self-interested discriminations struck down in Austin and Travis are examples of beggar-thy-neighbor policies that are unquestionably at odds with a national union. Indeed, such policies are policed by other constitutional doctrines as well, such as the Dormant Commerce Clause's concern with eliminating state protectionism. ${ }^{216}$

213 See Regan, supra note 27, at 1911 (providing similar analysis of Austin); cf. Lea Brilmayer, Credit Due Judgments and Credit Due Laws: The Respective Roles of Due Process and Full Faith and Credit in the Interstate Context, 70 IowA L. REV. 95, 101 n.31, 104 (1984) (noting the constitutional distinction between discrimination against another state's laws and consistent deference to the other state's laws). In Travis the Court struck down a New York law that granted exemptions to residents but not nonresidents. Of relevance to Austin was that the New York law in Travis was not saved by a provision that gave nonresidents a credit for taxes paid to their Home State on New York-derived income if their Home State gave a reciprocal credit to New York residents subject to that state's income taxes. New York had argued that this provision allowed the other states to circumvent New York's discrimination against their citizens by adopting income taxes that provided "similar exemptions similarly conditioned." Travis, 252 U.S. at 82. Responded the Court: "a discrimination by the State of New York against the citizens of adjoining states would not be cured were those States to establish like discriminations against citizens of the State of New

York. ... Nor can discrimination be corrected by retaliation ...." Travis, 252 U.S. at 82

214 Austin, 420 U.S. at 666-67.

215 Travis, 252 U.S. at 82.

216 See infra notes 277-98 and accompanying text (summarizing Dormant Commerce Clause jurisprudence as applying heightened scrutiny to state policies that are methods of 
Further, the Home State behavior invited by the statutory schemes in Austin and Travis to "correct[]" the Host State discrimination was retaliation, the avoidance of which "was one of the chief ends sought to be accomplished by the adoption of the Constitution." 217 None of this is true in the context of a Host State assisting a Home State to advance its policies vis-à-vis visitors from the Home State. The Host State is not discriminating against nonresidents generally, but is simply treating nonresidents from certain Home States the way the Home States want them to be treated. This is not the "evil at which" the Austin and Travis holdings are directed, namely, "the unilateral imposition of a disadvantage upon nonresidents.",218 To the contrary, Austin specifically did not "denigrate the value of reciprocity,",219 and Host State assistance of the Home State is more fairly characterized as a species of reciprocity rather than unilateral imposition of disadvantage.

A broader look at the caselaw confirms that the Privileges and Immunities Clause does not impose a flat obligation on the Host State to apply its laws to visitors from other states irrespective of the Home State's policies. If it did, there could not have been a case like Bradford Electric Light Co. v. Clapper, ${ }^{220}$ in which a Host State not only was permitted, but was required under the Full Faith and Credit Clause to apply the Home State's law. Indeed, a flat obligation would be wholly inconsistent with the well-established doctrine that the Privileges and Immunities Clause's

economic protectionism). See generally Donald H. Regan, The Supreme Court and State Protectionism: Making Sense of the Dormant Commerce Clause, 84 MICH. L. REV. 1091, 1114 (1986) (“[P]rotectionsim is conceptually inconsistent with political union.”).

217 Travis, 252 U.S. at 82.

218 Austin, 420 U.S. at 667. For a similar analysis, see Larry Kramer, The Myth of the "Unprovided-for" Case, 75 VA. L. RE V. 1045, 1065-69 (1989), which argues that one state's deference to another state's laws in respect of the second state's citizens may reduce interstate friction and thus be consistent with the Privileges and Immunities Clause; and Kramer, supra note 125, at 307 n.93 (1990), which presents "deference to the law of other States" as a justification for treating residents and non residents differently. A recent commentator has argued otherwise - stating that the clause "[b]y its words ... grants rights to individuals, not to their states" and observing correctly that "the Supreme Court has never suggested that states may waive the rights of their citizens to the privileges and immunities of other states' laws." Kermit Roosevelt III, The Myth of Choice of Law: Rethinking Conflicts, 97 MICH. L. REV. 2448, 2526 (1999). Such analysis, however, overlooks the fact that the clause does not apply to Home States, as shown above in the text.

219 Austin, 420 U.S. at 667 n.12.

220286 U.S. 145 (1932). Most scholars believe that the Clapper opinion has been overturned on the basis of subsequent full faith and credit caselaw. See, e.g., SCOLES ET AL., supra note 124, at 146 (stating that the Court has "abandoned the attempt to strike a balance between conflicting state interests" for which Clapper was cited). Regardless of Clapper's current status under full faith and credit, it could not have been decided as it was if the Privileges and Immunities Clause imposed a flat obligation on Host States to apply their laws to visitors. 
protections are not “'absolute.",221 States are permitted to draw lines between citizens and noncitizens-if there are good reasons for doing so. States may distinguish between residents and nonresidents if "there is a substantial reason for the difference in treatment" "and "the discrimination practiced against nonresidents bears a substantial relationship to the State's objective.,"222

There is a strong basis for concluding that a Host State's desire to further a Home State's policy with respect to its journeying citizens would qualify as a "substantial reason" for these purposes. ${ }^{223}$ The case of Sosna $v$. Iowa ${ }^{224}$ is instructive. There, the Court upheld, despite equal protection and right to travel challenges, an Iowa law that mposed a one-year residency requirement for those seeking a divorce, discriminating against noncitizens and new citizens alike. The Court held that the Iowa law justifiably reflected the state's desire to avoid "officious intermeddling in matters in which another State has a paramount interest." ${ }^{, 225}$ And what makes another state's interest paramount? The divorce petitioners' de facto citizenship: the petitioners for divorce in Iowa might really intend to return to their true Home State after obtaining an Iowa divorce, in which case their Home States have the paramount interest. ${ }^{226}$

To be sure, Sosna does not definitively answer the Privileges and Immunities Clause question; its holding did not address that clause, ${ }^{227}$ and it

221 Saenz v. Roe, 526 U.S. 489, $489-502$ (1999) (quoting Toomer v. Witsell, 334 U.S. 385,396 (1998)).

222 Lunding v. N.Y. Tax Appeals Tribunal, 522 U.S. 287, 298 (1998) (quoting Supreme Court of N.H. v. Piper, 470 U.S. 274, 284 (1985)). For examples of state laws discriminating between residents and nonresidents that were upheld against Privileges and Immunities Clause challenges, see Baldwin v. Fish \& Game Commission, 436 U.S. 371, 390-91 (1977), requiring nonresidents to pay more than residents for hunting licenses; and Vlandis v. Kline, 412 U.S. 441, 445 (1973), charging nonresidents higher tuition fees to attend state universities.

223 If so, it is axiomatic that applying the Home State's law would satisfy the second test of bearing a substantial relationship to the Host State's objective insofar as the Host State's application of the Home State's law is the only means by which the Host State can help to counter travel-evasion.

224419 U.S. 393 (1975).

225 Id. at 407.

226 As the Court wrote in Sosna:

A State such as Iowa may quite reasonably decide that it does not wish to become a divorce mill for unhappy spouses who have lived there as short a time as appellant had when she commenced her action in the state court after having long resided elsewhere. Until such time as Iowa is convinced that appellant intends to remain in the State, it lacks the "nexus between person and place of such permanence as to control the creation of legal relations and responsibilities of the utmost significance." Sosna, 419 U.S. at 407 (quoting Williams v. North Carolina, 325 U.S. 226, 229 (1945)).

227 Sosna preceded the general restatement of Privileges and Immunities Clause jurisprudence that the Court provided in Baldwin. One might ask why Sosna neglected to 
could be argued ${ }^{228}$ that Sosna's equal protection analysis demanded a lower level of scrutiny (the legislation "may reasonably be justified") than does the Privileges and Immunities Clause (which requires a "substantial reason" for differential treatment). At the very least, however, Sosna shows that there is constitutional weight to a Host State's desire not to interfere in the policy of a sister state. Furthermore, even if Sosna were read as requiring only a low-level reasonable basis scrutiny, the fact that the policy of noninterference satisfied such review in Sosna certainly does not mean it would not satisfy a stricter level of scrutiny under the Privileges and Immunities Clause. The conclusion that noninterference can be a substantial justification for differential treatment is buttressed by the normative analysis provided immediately below.

\section{Normative Considerations}

The propositions established in the preceding Subsections collectively mean that the Privileges and Immunities Clause does not prevent a citizen of State $A$ from being subject to State $A$ 's regulations even when she is in State $B$. To establish definitively the validity of the propositions, however, it must be shown that a federal system where citizens may be subject to their Home State's laws while traveling is normatively desirable.

Most of the work establishing the normative appeal of such a system was provided earlier in this Article, which shows the important respects in which a state would be hamstrung if it did not enjoy the power to regulate its citizens' out-of-state conduct and the benefits of political heterogeneity that result from allowing extraterritoriality. ${ }^{229}$ Even critics do not deny this.

mention the Privileges and Immunities Clause. After all, Sosna concerned access to courts, a right that early privileges and immunities caselaw identified as being protected under the clause, see, e.g., Canadian N. Ry. v. Eggen, 252 U.S. 553 (1920) (reaffirming the rights of citizens to bring actions in other states as set forth in Corfield v. Coryell, 6 F. Cas. 546, 55253 (C.C.E.D. Pa. 1823) (No. 3230)), as Baldwin itself recognized three years after Sosna was decided, see Baldwin, 436 U.S. at 383, 387 (noting that the fundamental right of access to courts had been identified in early caselaw). The likely answer is that the plaintiff in Sosna did not plead a privileges and immunities claim because she was a resident of Iowa, the state whose law she was challenging, and, as explained above, the Privileges and Immunities Clause does not apply to Home States. Supra Part II.A.2.

${ }^{228}$ Here I seek only to anticipate a possible objection, for in my view the Sosna opinion is unclear on the precise level of scrutiny the Court utilized. In addition to not precisely stating the level of review, the Sosna Court analyzed the equal protection question by drawing on cases that appear to have used more than merely rational basis review. See Sosna, 419 U.S. at 405 (citing to Shapiro v. Thompson, 394 U.S. 618, 634 (1969), which required a "compelling governmental interest"; Dunn v. Blumstein, 405 U.S. 330, 335 (1972), which required a "substantial and compelling interest"; and Memorial Hospital v. Maricopa County, 415 U.S. 250, 254 (1974), which required a "compelling" state interest).

229 See supra Part I.C.3 (contending that extraterritoriality justly prevents avoidance of 
Many of their arguments instead are made from the perspective of the goals of federal union and national unity. ${ }^{230}$ Professor Kreimer, as usual, puts the argument well:

[T] he citizens as individuals are "entitled" to local privileges and immunities when they visit neighboring states. As citizens from different states travel and interact on a basis of equality, they develop and maintain consciousness of themselves as equals and members of a single polity.

By contrast, a system in which my opportunities upon entering California remain subject to the moral demands of Pennsylvania undercuts this sense of national unity. Such a system would deny to me, because of my status as a Pennsylvanian, the privileges that the Californians I pass on the street share as their birthright. This situation hardly advances the goal of establishing a single national identity.

Although national unity long has been understood to be one of the clause's central goals, ${ }^{232}$ Professor Kreimer's argument does not support the weight of its conclusion. First, though it is true that all Americans are "members of a single polity," 233 it is equally certain that Americans simultaneously are members of one of fifty different subfederal polities known as states (not to mention of a far larger number of local

such things as state gambling and abortion regulations and permits states to advance paternalistic policies that promote the moral behavior of citizens, as well as those that protect third-party interests).

230 An additional argument is that applying the Home State's laws to its visiting citizens may interfere with legitimate Host State policies. This is a real potential cost, but I explain below why such costs do not mean that the Host State's legislative jurisdiction ought to trump the Home State's legislative jurisdiction as a per se matter. Infra Part II.D.1. Instead, a collection of constitutional and nonconstitutional principles appropriately govern this conflict between Home and Host States. Infra Part III. It seems to me that accounting for the competing states' interests is best done by const itutional provisions aside from the Privileges and Immunities Clause, which, by its terms, is directed to citizens, not states. In short, in my view the Supreme Court is correct in understanding the Privileges and Immunities Clause as a provision that grants protections for individuals against discriminations by Host States, and that has consequent effects on our nation's federal union, but not as a clause that has as its primary subject the states.

231 Kreimer, Whoever Treasures Freedom, supra note 49, at 919.

${ }^{232}$ For an early exposition of this, see Paul v. Virginia, 75 U.S. 168, 180 (1868), in which the Court stated: "It has been justly said that no provision in the Constitution has tended so strongly to constitute the citizens of the United States one people as this." For a more recent statement, see Toomer v. Witsell, 334 U.S. 385, 395 (1948), in which the Court stated: "The primary purpose of [the Privileges and Immunities Clause] . . was to help fuse into one Nation a collection of independent, sovereign States." Both the Paul and Toomer formulations have been quoted with approbation in numerous subsequent cases. See, e.g., Hicklin v. Orbeck, 437 U.S. 518, 524 (1978) (citing to the formulation from Paul); Baldwin v. Fish \& Game Comm'n, 436 U.S. 371, 380 (1978) (same); New Hampshire v. Piper, 470 U.S. 274, 279 (1985) (citin g to the formulation from Toomer); United Building and Constr. Trades Council v. City of Camden, 465 U.S. 208, 216 (1984) (same).

${ }^{233}$ Kreimer, Whoever Treasures Freedom, supra note 49, at 919. 
governments). The dialectic between oneness (national unity) and differentness (subfederal heterogeneity) is the essence of federalism. As a purely methodological matter, looking at only one pole of the dialectic, as Professor Kreimer's national unity-focused argument does, is inadequate for the task of critically analyzing extraterritoriality. Any serious doctrinal or theoretical analysis must take into account both poles of the dialectic. ${ }^{234}$

Second, Professor Kreimer's argument rests on an unexplained, yet nonaxiomatic, assumption about the nature of our country's national identity. It assumes without explanation that a regime in which Home States could regulate their citizens' out-of-state conduct is inconsistent with national unity. But this is not self-evident. Let the analysis of this matter start with two definitions. Under a regime of "hard" legal pluralism, a state may insist that its citizens abide by constitutional substantive policies even when they venture out of state. Under a "soft" regime of legal pluralism, a state's regulations end at its borders, and national citizenship entails the right of a non-Iowan to do in Iowa what Iowans are permitted to do under their Iowa law.

The question is: Is our country's national identity only consistent with a regime of "soft" pluralism, as Professor Kreimer's analysis assumes? At issue is the nature and extent of the legal pluralism across the country concerning those substantive policies for which the Federal Constitution does not require national uniformity. It simply is untrue that "hard" pluralism is logically inconsistent with a national political community. It is at least plausible that the substantive limitations imposed by the Constitution, along with the broad swaths of federal law and regulations, are sufficient to create a national identity. Indeed, one might suggest that part of that national identity is permitting states to differ radically about substantive issues not foreclosed to them under the Constitution, even to the extent of requiring that their citizens abide by their laws when traveling in

234 Ignoring the "differentness" end of the dialectic is the imperfection in Professor Kreimer's argument that a regime in which each state citizen is "equally bound by the law of [her] Home State" runs afoul of the Privileges and Immunities Clause's guarantee. Id. He argues that it is untrue that "each citizen will be equally subject to the laws of her Home State" because no Host States grant visitors exemptions from their local criminal law so as to replicate the legal regime of the visitor's Home State. Id.; see also Brilmayer, supra note 26, at 887-89 (making virtually the identical argument in the abortion context). This is true but immaterial insofar as there is no mandate of absolute equality; each citizen belongs to a different subfederal polity, and this difference explains why some citizens might be subject to their Home State's laws while traveling and others might not. See, e.g., Baldwin v. Fish \& Game Comm'n, 436 U.S. 371, 383 (1978) ("Some distinctions between residents and nonresidents merely reflect the fact that this is a Nation composed of individual States, and are permitted; other distinctions are prohibited because they hinder the formation, the purpose, or the development of a single Union of those States."). 
other states. $^{235}$

Such a federal scheme of "hard" pluralism is not an oxymoron that "hardly advances the goal of establishing a single national identity." "236 The national identity that such a system fosters is one that permits rich pluralism and heterogeneity in respect of those policies that are constitutionally permissible for a state to pursue. "Soft" pluralism, by contrast, systemically disfavors states that regulate matters that other states elect not to regulate, thereby undermining diversity across and experimentation among states. ${ }^{237}$ Surely, one tie binding the states and preserving national identity is the right of states to differ from each other in their policies and politics. Furthermore, a "hard" pluralism regime may well be the logical autgrowth of Rawlsian liberal commitments; only such a regime can accommodate persons having both atomistic and more communal political philosophies, and people in the "original position," not knowing the persons they actually represent, would think it fair to select a political structure that could accommodate a broad array of persons that would include those who are both atomistic and communitarian-minded. ${ }^{238}$ The national identity of a regime of "hard" pluralism allows both liberals and communitarians to govern themselves within subfederal communities as they deem fit within the range of policy options that the Federal Constitution leaves open to them. Such a conception of national identity is not a contradiction-in-terms. Indeed, there is evidence of its plausibility in that contemporary law already permits "hard" pluralism in at least some circumstances: Under the Model Penal Code, for example, a Home State may impose criminal liability on activities undertaken in another state in which the activity is permissible. ${ }^{239}$

To be sure, "hard" pluralism is not an axiomatic form of national

235 Donald H. Regan's article cites to an analogous proposition:

We are a single nation, but we are a nation constituted of separate states, with separate legal systems. The Constitution expressly recognizes the reality and significance of state citizenship, both in article IV and in the fourteenth amendment. Why should we not think of a state as having an interest in its citizens which justifies regulation of their conduct wherever they may be?

Regan, supra note 27, at 1908.

236 Kreimer, Whoever Treasures Freedom, supra note 49, at 919.

237 See supra Part I.C.3 (arguing that allowing extraterritorial regulation of citizens to curb travel-evasion promotes political heterogeneity).

238 See RAWLS, supra note 114, at 27 (contending that the "veil of ignorance" feature of the "original position" concept "has no specific metaphysical implications concerning the nature of the self"); see also supra text accompanying notes 137-50 (explaining why the just liberal state would accommodate the broadest possible array of persons).

239 See infra notes 398-406 and accompanying text (discussing the MODEL PENAL CODE $\S 1.03$ (1985), which grants the Home State legislative jurisdiction under these circumstances). 
identity. The relevant point here, however, is that neither is the national identity presumed by Professor Kreimer's argument, as this brief discussion of a plausible alternative, "hard" pluralism, shows. ${ }^{240}$ The nature of our national identity is deeply contested, and bald appeals to "national identity" of the sort made by Professor Kreimer cannot decide the question at issue. The doctrinal status quo is not premised on a philosophy that is flatly at odds with our national identity. Though incompatible with "soft" pluralism, that status quo is perfectly consistent with a "hard" pluralist approach to our national identity. The burden is on those who advocate the radical retooling of our longstanding privileges and immunities doctrines, and the argument propounded by Professor Kreimer does not suffice to counter the potent considerations that counsel in favor of the "hard" pluralist conception of national identity that contemporary law permits.

\section{B. Right to Travel}

The right to travel imposes a modest but important limit on Home States' powers to regulate their citizens' out-of-state activities: A Home State cannot interfere with its citizens' rights to leave for the purpose of visiting another State nor prevent its citizens from returning. Either would violate "the right of a citizen of one State to enter and to leave another State." 241 The recent case of Saenz v. Roe noted two other components of the right to travel, neither of which is implicated by a Home State's

${ }^{240}$ Several of Professor Kreimer's other arguments fall prey to the same error of presuming a nonaxiomatic nature of the national identity. For example, Professor Kreimer argues that the alternative approach of allowing citizens to be governed by their Home State's law "emphasizes the differences between individuals as citizens of different states rather than their commonalties" and thereby "undercuts rather than fosters common national citizenship." Kreimer, Whoever Treasures Freedom, supra note 49, at 920. He also baldly asserts that the clause "imparts to individual American citizens the freedom that accompanies national citizenship," in particular the ability to "take advantage of opportunities legal in other states." Id. As a final example, Professor Kreimer argues that prohibiting its citizens from engaging in behaviors that are permitted under Host State laws would constitute an unconstitutional "abridge[ment]" of the attributes of national citizenship under the "fourteenth amendment's privileges and immunities clause." See Kreimer, Law of Choice, supra note 5, at 517-18 (discussing a woman's right to obtain an abortion outside of her Home State). All of these arguments assume without argument that included among the rights inherent in national citizenship is a visitor's unconditional right to be governed by the Host State's regulations, irrespective of the Home State's laws. This unargued premise appears to be connected, once again, to Professor Kreimer's nonaxiomatic understanding of national identity. An additional problem with the last argument is that the case on which it is premised, Colgate v. Harvey, 296 U.S. 404, 431 (1935), has been overruled, as Professor Kreimer himself notes. See Kreimer, Law of Choice, supra note 5, at 518 (noting that the decision was overruled in Madden v. Kentucky, 309 U.S. 83 (1940)).

241 Saenz v. Roe, 526 U.S. 489, 500 (1999). 
regulation of its citizens' out-of-state activities. The Constitution guarantees travelers the "right to be treated as a welcome visitor rather than an unfriendly alien when temporarily present in the second State. ${ }^{, 242}$ This is the protection afforded by the Privileges and Immunities Clause of Article $\mathrm{IV},{ }^{243}$ and for the reasons discussed above this does not apply to the Home State and hence would not preclude a Host State from applying Home State law to a visitor for the purpose of aiding the sister Home State. ${ }^{244}$ The third aspect of the right to travel, "the right of the newly arrived citizen to the same privileges and immunities enjoyed by other citizens of the same State, ${ }^{, 25}$ plainly is not implicated by Host State regulation of its citizens' out-of-state activities.

Professor Kreimer has proposed a more expansive understanding of the right to travel that would severely curtail a Home State's power to regulate its citizens' out-of-state conduct. He argues that the very point of the right to travel is to "undermine[] parochial conformity" by "provid[ing] us with the ability to experiment with modes of living other than those sanctioned at home and to return with the potentially transformative knowledge we have gained." "246 As a consequence, he argues, "[a] system that allows states to truncate these experiments by allowing travel but punishing its object has the effect of undercutting this liberty.,"247

No case has suggested that the right to travel encompasses a general right (much less an ostensibly unconditional right) to behave as the citizens in the host jurisdiction do. ${ }^{248}$ Professor Kreimer apparently recognizes this, for his argument here, in contrast to his others, is bereft of relevant caselaw citation. $^{249}$ The absence of such a doctrine is a good thing. Traveling, even

242 Id.

243 See id. at 501 ("The second component of the right to travel is, however, expressly protected by the text of the Constitution, [in Article IV, Section 2, the Privileges and Immunities Clause].").

244 See supra Parts II.A.2-.3 (concluding that noninterference with the Home State's regulation of its citizens can be a substantial reason for purposes of justifying treating visitors differently from residents).

245 Saenz, 526 U.S. at 502.

246 Kreimer, Whoever Treasures Freedom, supra note 49, at 915.

247 Id.

248 The most recent restatement of the right to travel, which surveys caselaw dating back to 1823 in its attempt to articulate the doctrine, Saenz, 526 U.S. at 498-511, certainly does not embrace such a theory. It cannot readily be fit into any of the three components of the right to travel identified by the Court. The most promising candidate, "the right of a citizen of one State to enter and to leave another State," $i d$. at 500, refers to the right not to be actually obstructed from "ingress and regress to and from" neighboring states, as the caselaw cited by the Saenz Court in explaining this aspect of the right to travel makes clear, id. at 501 .

249 See Kreimer, Whoever Treasures Freedom, supra note 49, at 915-17 (citing only to The Federalist No. 10, at 22 (James Madison) (Roy P. Fairchild ed., 1981), to buttress his 
without a concomitant Kreimerian right to do as the natives do, allows the visitor to learn all sorts of things, and she can then return to her home jurisdiction and seek to convince others in her political community of the wisdom of such alternative ways. ${ }^{250}$ But unilaterally taking upon herself to do in a foreign jurisdiction those things that her home jurisdiction has sought to proscribe is another matter. "[M]odes of living other than those sanctioned at home ${ }^{, 251}$ frequently entail third-party effects and, in addition, may serve to socialize the actor to modes of behavior that the Home State paternalistically wishes to discourage. For example, gambling produces third-party effects on both the gambler's family and the Home State that must absorb the bulk of the costs of the family's becoming public charges. Consider as well a hypothetical jurisdiction that eliminated the sanctions that attend adultery; a philanderer's out-of-state sexual acts may well have third-party effects on his spouse and children. Attendant costs that flow from such activities (such as funding the judges who will hear the divorce case) fall primarily on the Home State. Furthermore, neighbors' out-of-state activities might well shape local norms in ways that the Home State wishes to fight against; there is evidence to suggest that the behaviors of people we know play an important role in shaping our sense of what behaviors are acceptable. $^{252}$

For these reasons, I believe that Professor Kreimer is incorrect when he states that " $[w]$ hen I visit California, my actions, whatever they may be, do not threaten the public order of Pennsylvania any more than the actions of Californians do." ${ }^{, 253}$ Such an assertion ignores third-party effects and normshaping motivations that the Constitution permits states to take account of in formulating their laws. ${ }^{254}$ In short, it sometimes is the case that Pennsylvania's concerns are undermined by a visiting Pennsylvanian's

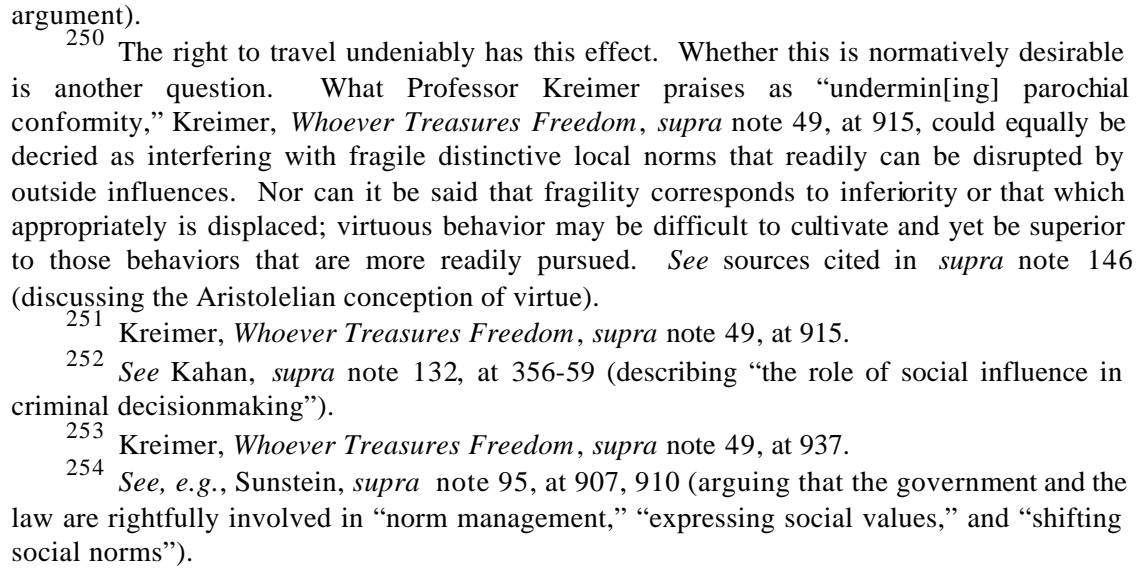
decried as interfering with fragile distinctive local norms that readily can be disrupted by outside influences. Nor can it be said that fragility corresponds to inferiority or that which appropriately is displaced; virtuous behavior may be difficult to cultivate and yet be superior to those behaviors that are more readily pursued. See sources cited in supra note 146 (discussing the Aristolelian conception of virtue)

251 Kreimer, Whoever Treasures Freedom, supra note 49, at 915.

252 See Kahan, supra note 132, at 356-59 (describing "the role of social influence in criminal decisionmaking").

253 Kreimer, Whoever Treasures Freedom, supra note 49, at 937.

254 See, e.g., Sunstein, supra note 95, at 907, 910 (arguing that the government and the law are rightfully involved in "norm management," "expressing social values," and "shifting social norms"). 
actions in California, even though Pennsylvania is unaffected by the Californian's identical activity in California. This is true because the welfare of other Pennsylvanians is interconnected with the visiting Pennsylvanian's welfare in ways that it is not interconnected with the Californian's. That is part of what it means to share a political community with another person, and fellow Pennsylvanians share a political community in a way that a Pennsylvanian and Californian do not. ${ }^{255}$

Interestingly, Professor Kreimer asserts that his conception of the right to travel advances the values of "diversity and experimentation," whereas a system under which Home States retain regulatory authority over their citizens' out-of-state activities compromises such values. ${ }^{256}$ His argument is that "[i]f the only way to escape from the force of a state's laws is to move to another state, we can expect increasing moral homogeneity in the state, as the most passionate or mobile dissenters relocate to other jurisdictions., 257

I believe that this argument misconceives the conception of diversity that is relevant to federalism and that, properly understood, it is in fact Professor Kreimer's conception of the right to travel that threatens diversity. It seems to me that the relevant level of analysis for purposes of understanding federalism's diversity benefits is the nation as a whole: Does one set of institutional arrangements permit more or fewer meaningful political options across subfederal polities? Political diversity at the subfederal level is particularly meaningful if the various options themselves are important enough that some people will want to be subject to one set of political institutions and that other people will want to be subject to others. Thus, meaningful diversity of political regimes at the subfederal level naturally leads to "increasing moral homogeneity" at the subfederal level insofar as those who prefer a particular set of political institutions or laws are likely to elect to locate themselves in the subfederal polity that satisfies those political desires. ${ }^{258}$ Perceived from the federal level, such localized homogenization could be said to be one of the very foundations and goals of

255 That the Californian and Pennsylvanian share a national political community does not undermine this point. The more intimate political community of common statehood entails additional financial interconnections insofar as many citizens' needs are financed primarily or exclusively by state rather than federal funds. Furthermore, insofar as norm-shaping is a function of proximity and personal knowledge of those who are engaging in the behaviors in question, the behaviors of one's fellow state citizens may matter more than the behaviors of people from other states.

256 See Kreimer, Whoever Treasures Freedom, supra note 49, at 915-16.

257 Id.

258 Cf. Charles M. Tiebout, A Pure Theory of Local Expenditures, 64 J. POL. ECON. 416 (1956) (outlining an economic model showing efficiencies arising from different distributions of public goods across polities). 
federal diversity.

Conversely, dampening the "moral homogeneity" at subfederal levels in the manner advocated by Professor Kreimer comes at a cost: increasing political homogeneity across subfederal polities. People who feel strongly about politics are less apt to "vote with their feet" and move to a political community for the purpose (at least in part) of joining that community to the extent there is little difference among polities. Professor Kreimer's conception of the right to travel would have such an effect of diminishing the significance of which State's political community a person is part of; this is the natural result of granting all citizens of the United States a right to opt-in to any state's laws on an issue-by-issue basis while remaining a citizen of a single state.

Furthermore, Professor Kreimer's proposal would not diminish diversity across polities in a neutral manner, but would operate as a systematic bias toward the most lenient substantive state policies. It would grant as a matter of federal constitutional law a personal right for citizens to engage in traverevasion and thereby circumvent Home State laws that seek to protect third-party effects, advance paternalistic concerns, and shape local norms. ${ }^{259}$ Certain political theories are more prone to seek to advance these concerns through regulation; in particular, communitarian, republican, and neo-Aristotelian pproaches to politics would more likely advocate such regulation. Adherents of these political commitments would be significantly hampered in advancing their agendas, whereas political philosophies that are less regulation-minded (such as libertarianism) would be little affected. Such systematic disadvantaging of one set of political philosophies is another respect in which a Kreimerian right to travel would undermine diversity among states and the possibilities of experimentation across polities. ${ }^{260}$

259 Moreover, in contrast to the limitations imposed by other constitutional doctrines explored above (Full Faith and Credit, Privileges and Immunities, and the Dormant Commerce Clauses), such a right to travel limitation may constrain the Congress as well as the states; the Supreme Court has suggested that certain aspects of the right to travel limit the federal government. See Saenz, 526 U.S. at 507 (noting that Congress may not allow states to violate the Fourteenth Amendment by creating residency requirements as part of welfare programs). A Kreimerian right to travel thus might flatly preclude the accommodation of Home States' interests in a way that the aforementioned other doctrines do not, for the other doctrines impose limitations on states that leave unfettered the congressional power to require Host States to accommodate Home States' interests, as Congress sought to do last year in the Child Custody Protection Act. See supra note 11 and accompanying text (noting the passage of legislation which would have made the transportation of a minor across state lines in order to circumvent the Home State's parental notification and/or notice laws a federal crime, other than in the case of a parent of the minor).

${ }^{260}$ See supra Part I.C.3.b (arguing for political heterogeneity). 
Moreover, limiting political diversity across subfederal polities may even lead to increasing moral homogeneity of the sort that Professor Kreimer is concerned. Insofar as law may have a socializing effect that cannot be reproduced by other social institutions, foreclosing certain forms of political institutions might actually preclude certain forms of social life from developing or maintaining themselves over time. ${ }^{261}$ Diminishing political diversity thus may diminish the diversity of the people found in society as a whole, thereby leading to increasing moral homogeneity of the sort that Professor Kreimer decries.

In short, there is more than one aspect of "diversity," and the relationship among those aspects is complex. In some respects they may be mutually incompatible; "diversity" of members in a political community may come at the cost of "diversity" of polities insofar as that diversity of members is achieved by undermining the differences across polities that attract one or another sort of person to live there. ${ }^{262}$ On the other hand, these two aspects of diversity may be directly related, but in the opposite direction Professor Kreimer suggests: diminishing the range of political options may well lead to increasing homogeneity of persons across the country as certain forms of social life are not given room to survive. In any event, achieving the type of "diversity" Professor Kreimer discusses comes at the expense of the aspects of diversity that federalism arguably is most concerned with: diversity of political institutions and laws across states. To date, the caselaw has not construed the right to travel in the manner Professor Kreimer has proposed. In so large and diverse a country as ours, the theory advanced by Professor Kreimer would be a troublesome clamp on the experimentation and political heterogeneity that federalism allows. Apart from the modest limitation discussed above of not precluding exit or re-entry, the right-to-travel caselaw wisely does not bar Home States from regulating the out-of-state conduct of their citizens.

\section{Dormant Commerce Clause}

Another body of constitutional doctrine that offers important limitations

\footnotetext{
261 See RAWLS, supra note 114, at 193-97 (noting that democratic regimes can lead to the demise of certain forms of social life even when the state does not discriminate against them). See generally Rosen, Outer Limits, supra note 109, at 1063-71 (describing communities that believe their members will be unable to fully realize themselves unless political institutions can assist them in leading virtuous lives); Rosen, "Illiberal" Societal Cultures, supra note 141 (manuscript at 5-6) (discussing respects in which general society's political institutions might impede the survival of valuable cultures).

262 I say "may come" because it surely is possible that a given polity might have a political ethic of membership diversity.
} 
on Home States' powers to regulate their citizens' out-of-state conduct is the Dormant Commerce Clause. Before examining this field of law, however, it should be recalled that Dormant Commerce Clause limitations are not absolute, for Congress can exercise its powers under the Commerce Clause and permit what the Supreme Court's Dormant Commerce Clause jurisprudence disallows. ${ }^{263}$ Dormant Commerce Clause prohibitions nonetheless erect significant burdens on the states as a practical matter, for they must successfully lobby Congress to reverse a problematic Dormant Commerce Clause decision.

\section{Extraterritoriality and Inconsistent Regulations}

There is a line of Dormant Commerce Clause caselaw in which the Court has stated that it was striking down "extraterritorial legislation" that "directly controls commerce occurring wholly outside the boundaries of a State. $^{264}$ The Court has said that such laws are virtually per se unconstitutional. ${ }^{265}$ Taken out of context, language in these cases appears to flatly prohibit Home States from regulating their citizens' out-of-state conduct. $^{266}$ Indeed, the United States Court of Appeals for the Seventh

263 See Maine v. Taylor, 477 U.S. 131, 138 (1986) ("It is well established that Congress may authorize the States to engage in regulation that the Commerce Clause would otherwise forbid."); see also New York v. United States, 505 U.S. 144 (1992) (standing for the same proposition, in holding that Congress may grant states the right to regulate interstate transportation of radioactive waste).

264 Healy v. Beer Inst., 491 U.S. 324, 336 (1989). One of the earliest principal cases is Baldwin v. G.A.F. Seelig, Inc., 294 U.S. 511, 521 (1935), which famously stated that "New York has no power to project its legislation into Vermont by regulating the price to be paid in that state for milk acquired there." Baldwin struck down a provision of New York law that set a minimum price at which milk distributors in New York could purchase milk from Vermont that would be sold in New York, and prohibited milk purchased at prices below that minimum from being sold in New York. Id.

265 See Healy, 491 U.S. at 336 ("[A] statute that directly controls commerce occurring wholly outside the boundaries of a State exceeds the inherent limits of the enacting State's authority and is invalid regardless of whether the statute's extraterritorial reach was intended by the legislature."). For example, the Court held unconstitutional a New York law that forced alcohol distributors to post at the beginning of the month the price of alcohol they were selling outside New York for that month. Brown-Forman Distillers Corp. v. N.Y. State Liquor Auth., 476 U.S. 573, 585 (1986). The law also required that the alcohol be sold to New York wholesalers for no more than the posted price. As a result of the law, "[o]nce a distiller has posted prices in New York, it is not free to change its prices elsewhere in the United States during the relevant month. Forcing a merchant to seek regulatory approval in one State before undertaking a transaction in another directly regulates interstate commerce." $I d$. at 582. The law was struck on the ground that New York could not " project its legislation into [other states] by regulating the price to be paid"" for liquor in those states. Id. at 582-83 (quoting Baldwin, 294 U.S. at 521).

266 See, e.g., Healy, 491 U.S. at 336 (classifying a regulation as a violation of the Dormant Commerce Clause if "the practical effect of the regulation is to control conduct 
Circuit recently relied on the Dormant Commerce Clause to strike down a Wisconsin regulation that sought to counter travel-evasion in the business context. $^{267}$ Analyzed more closely, however, the Dormant Commerce Clause cases concerning extraterritoriality are best understood as standing for a narrow principle that does not affect the extraterritorial regulations that are the subject of this Article (and, furthermore, that should not have led to the demise of Wisconsin's regulation).

\section{a. Commerce}

To begin with, the Dormant Commerce Clause's extraterritorial limitations are not flat prohibitions against extraterritorial regulation, but instead only apply to such regulations that concern "commerce." ${ }^{, 268}$ Recent Commerce Clause caselaw has identified important limits on Congress's Commerce Clause powers, ${ }^{269}$ and these likewise limit the scope of the Dormant Commerce Clause; ${ }^{270}$ after all, the Dormant Commerce Clause is understood to limit State activity in respect of matters about which Congress has not legislated, but over which Congress has the power to regulate. Thus, the Dormant Commerce Clause concerns only those activities that themselves constitute interstate commerce or those activities that are "economic endeavor[s]" and have "substantial effects on interstate commerce." $" 71$ To fall under the Dormant Commerce Clause, the activity would have to concern "what is truly national" rather than "what is truly local." 272

Though the precise boundaries erected by this language are unclear, the general implication is clear enough: not every activity is potentially subject

\footnotetext{
beyond the boundaries of the State").

267 I critically analyze the case immediately below in Part II.C.2.

268 See, e.g., CTS Corp. v. Dynamics Corp. of Am., 481 U.S. 69, 87-88 (1987) ("The principal objects of dormant Commerce Clause scrutiny are statutes that discriminate against interstate commerce. . . . This Court's recent Commerce Clause cases also have invalidated statutes that may adversely affect interstate commerce ...."); Edgar v. MITE Corp., 457 U.S. 624, 642 (1982) ("The Commerce Clause ... precludes the application of a state statute to commerce that takes place wholly outside of the State's borders ...." (emph asis added)).

269 See, e.g., United States v. Morrison, 529 U.S. 598, 617 (2000) ("We accordingly reject the argument that Congress may regulate noneconomic, violent criminal conduct based solely on that conduct's aggregate effect on interstate commerce."); United States v. Lopez, 514 U.S. 549, 558-60 (1995) (holding that congressional Commerce Clause power is limited to regulating channels of interstate commerce, instrumentalities of commerce, and activities that substantially affect interstate commerce).

${ }^{270}$ See Camps Newfound/Owatonna, Inc. v. Town of Harrison, 520 U.S. 564, 573 (1997) (citing Lopez for its narrowing definition of "articles of commerce").

271 Morrison, 529 U.S. at 611.

272 Id. at 617-18; Lopez, 514 U.S. at 567-68.
} 
to the Dormant Commerce Clause's limitations. The Dormant Commerce Clause caselaw creates a two-tiered system in which a state's extraterritorial powers in relation to "commerce" are less than the state's powers with respect to the general police powers (such as criminal law). The reason for the stricter limitations on states in the context of commerce is well understood. Whereas the Constitution created a federal system wherein each State can pursue its own vision of the social good, it also created a single national market; thus although states " "as political communities, [are] distinct and sovereign, and consequently foreign to each other",273 for purposes of criminal law and most police powers, "the states are not separable economic units.",274 "“[W] hat is ultimate"” under the Dormant Commerce Clause, the Court has said, "'is the principle that one state in its dealing with another may not place itself in a position of economic isolation.",275 The Court has also established that "our economic unit is the Nation, which alone has the gamut of powers necessary to control of the economy. ${ }^{276}$ Accordingly, any Dormant Commerce Clause bar on extraterritoriality should not apply to matters unconcerned with the national market, as determined by Lopez and its progeny.

\section{b. Protectionism}

Although the Court has not yet directly confronted the question, ${ }^{277}$ a strong argument can be made that the Dormant Commerce Clause's near per se prohibition of extraterritorial regulation, the clause's form of heightened scrutiny, applies only to state statutes that are forms of economic protectionism. This would be consistent with general Dormant Commerce Clause doctrine, under which heightened scrutiny is applicable only if the state regulation is a species of "economic protectionism," and thus not applicable to "health and safety" regulations. ${ }^{278}$ It has long been held that

273 Heath v. Alabama, 474 U.S. 82, 93 (1985) (alteration in original) (quoting Bank of United States v. Daniel, 37 U.S. (12 Pet.) 32, 53-54 (1838)).

274 City of Philadelphia v. New Jersey, 437 U.S. 617, 623 (1978) (quoting H.P. Hood \& Sons, Inc. v. Du Mond, 336 U.S. 525, 538 (1949)).

275 City of Philadelphia, 437 U.S. at 623 (quoting Baldwin v. G.A.F. Seelig, Inc., 294 U.S. 511, 527 (1935)).

276 Hood, 336 U.S. at 537.

277 It has not been directly confronted because no case before the Supreme Court has pitted the states' traditional police powers against a claim of problematic extraterritoriality under the Dormant Commerce Clause. For discussion of such a case heard in the Court of Appeals for the Seventh Circuit, see infra Part II.C.2.

278 See Sporhase v. Nebraska ex rel. Douglas, 458 U.S. 941, 956 (1982) (noting that "[f]or Commerce Clause purposes, we have long recognized a difference between economic protectionism, on the one hand, and health and safety regulation, on the other"). 
although the "State may not promote its own economic advantages by curtailment or burdening of interstate commerce," there is "broad power in the State to protect its inhabitants against perils to health or safety, fraudulent traders and highway hazards, even by use of measures which bear adversely upon interstate commerce." ${ }^{, 279}$ The 1949 case of H.P. Hood \& Sons v. Du Mond, for example, noted that the

distinction between the power of the State to shelter its people from menaces to their health or safety and from fraud, even when those dangers emanate from interstate commerce, and its lack of power to retard, burden or constrict the flow of such commerce for their economic advantage, is one deeply rooted in both our history and our law. 280

Modern Dormant Commerce Clause caselaw maintains this distinction between economic protectionism, on the one hand, and "health and safety" regulations that only incidentally affect interstate commerce, on the other. Laws that amount to "simple economic protectionism" are virtually per se invalid, ${ }^{281}$ while health and safety regulations are subject to a far more deferential review ${ }^{282}$ under which the law will be struck down only if it imposes costs on interstate commerce that are "clearly excessive in relation to the putative local benefits. ${ }^{, 283}$ For example, in Head v. New Mexico Board of Examiners in Optometry, ${ }^{284}$ the Court upheld a state law that "unquestionably imposed some restraint upon [interstate] commerce"

279 Hood, 336 U.S. at 531-32.

280 Id. at 533. In terms of history, the Court noted that "[t]he sole purpose for which Virginia initiated the movement which ultimately produced the Constitution" was to create nationwide commercial harmony. Id. "The desire of the Forefathers to federalize regulation of foreign and interstate commerce stands in sharp contrast to their jealous preservation of the state's power over its internal affairs" concerning the "social conditions" of the states. Id. at 533-34.

281 See, e.g., Maine v. Taylor, 477 U.S. 131, 138, 144 (1986) (noting that state statutes that "affirmatively discriminate against" interstate commerce "are subject to more demanding scrutiny" known as "the strictest scrutiny"); City of Philadelphia v. New Jersey, 437 U.S. 617, 624 (1978) (noting the "virtually per se rule of invalidity" for laws reflecting "economic isolation" and "simple economic protectionism").

282 Some have argued that nonprotectionist state statutes should be subject to no Dormant Commerce Clause review at all. See Camps Newfoundland/Owatonna, Inc. v. Town of Harrison, 520 U.S. 564, 608 (1997) (Scalia, J., dissenting) ("[J]ust as a public health justification unrelated to economic protectionism may justify an overt discrimination against goods moving in interstate commerce, 'so may health and safety considerations be weighed in the process of deciding the threshold question whether the conditions entailing application of the dormant Commerce Clause are present." (quoting Gen. Motors Corp. v. Tracy, 519 U.S. 278, 307 (1997))); Regan, supra note 216 (arguing that the Dormant Commerce Clause properly addresses only economic protectionism and arguing that there is no lower-level Pike balancing in relation to nonprotectionist state legislation).

283 Pike v. Bruce Church, Inc., 397 U.S. 137, 142 (1970).

284374 U.S. 424 (1963). 
because the Dormant Commerce Clause was "never intended to cut the States off from legislating on all subjects relating to the health, life, and safety of their citizens, though the legislation might indirectly affect the commerce of the country. ${ }^{, 285}$ Laws "addressed to protection of the public health," which are part of what "is compendiously known as the police power," are constitutional if they "[do] not discriminate against interstate commerce or operate to disrupt its required uniformity.",286

The Dormant Commerce Clause jurisprudence that speaks of a near per se prohibition of extraterritoriality likewise should be understood as applying only to protectionist state statutes; some lower-level balancing of the local interests against the costs imposed on interstate commerce is appropriate in respect of statutes emanating from the state's historical police powers that regulate extraterritorially. ${ }^{287}$ The identical policy and historical reasons enumerated in Hood and pplied in Head to explain why state statutes concerning citizens' safety and welfare should be treated more deferentially than protectionist regulations are equally applicable to state statutes intended to regulate the health, life, and safety of citizens, even when those statutes must regulate those citizens' extraterritorial conduct to be effective. Indeed, as a descriptive matter it clearly is true that "[s]tate regulations are routinely upheld despite what is obviously a significant impact on outside actors"; ${ }^{288}$ consider, for example, products liability actions against out-of-state manufacturers and nuisance actions against polluters across the border. ${ }^{289}$ The types of laws that have been discussed in

285 Id. at 427-28 (internal quotations omitted).

286 Id. at 428-29 (internal quotations omitted)

287 For an excellent recent article that also concludes that extraterritoriality does not, and should not, per se run afoul of the Dormant Commerce Clause, see Jack L. Goldsmith \& Alan O. Sykes, The Internet and the Dormant Commerce Clause, 110 YALE L. J. 785, 803-06 (2001), which discusses some of the many state laws that have the effect of extraterritorially regulating and advocates a balancing test for evaluating extraterritorial state laws under the Dormant Commerce Clause.

It might be asked why the Dormant Commerce Clause doctrine concerns itself with extraterritoriality if such extra-state regulation only is problematic in the context of protectionism, which itself is subject to heightened scrutiny. See, e.g., Sporhase v. Nebraska ex rel. Douglas, 458 U.S. 941, 957-58 (1982) (noting that where a statute serves as "an explicit barrier to commerce between" two states, the restriction must be "narrowly tailored" to a nondiscriminatory policy). The answer is that extraterritoriality is a tool that can help to smoke out protectionism, which frequently is difficult to identify definitively, since extraterritoriality not infrequently is also present where there is protectionism. The suggestion of protectionist intent is particularly strong where, as is true in the Supreme Court's Dormant Commerce Clause extraterritoriality cases, the party to whom the regulation primarily is extraterritorially applied is not a citizen of the regulating state.

288 Goldsmith \& Sykes, supra note 287 , at 803.

289 Id. 
this Article would readily qualify as nonprotectionist. They do not "shield[] in-state industries from out-of-state competition" ${ }^{290}$ or otherwise benefit instaters at the expense of out-of-staters. ${ }^{291}$ Even if the economic burden of a law fell primarily or exclusively on out-of-staters, as would be the case if a Home State prohibited gambling in its midst and also sought to disallow its citizens from gambling out of state, that would not propel a state statute into the category of protectionist under the Dormant Commerce Clause jurisprudence. ${ }^{292}$ The question is whether a state statute gives in-staters a competitive advantage in the marketplace over out-of-staters, ${ }^{293}$ and the statutes discussed in this Article are not of that sort. They accordingly should not trigger the Dormant Commerce Clause's rule of per se invalidity of extraterritorial regulation.

Understanding the rule of per se invalidity of extraterritorial regulation as applying only to protectionist statutes works well with the holdings of the caselaw. Although several of the extraterritorial cases admittedly have deployed language that is not limited to protectionist statutes, ${ }^{294}$ all but one of the Supreme Court cases that have struck down state regulations on the basis of extraterritoriality have concerned statutes that are readily characterized as protectionist. $^{295}$ In the singular exception, Edgar v. MITE

290 Maine v. Taylor, 477 U.S. 131, 148 (1986).

291 See Hunt v. Wash. Apple Adver. Comm'n, 432 U.S. 333, 351-52 (1977) (holding that a North Carolina protectionist law favoring in-state dealers at the expense of out-of-state dealers violated the Commerce Clause).

292 See Exxon Corp. v. Governor of Md., 437 U.S. 117, 125 (1978) (stating that "the fact that the burden [of a state regulation] falls solely on interstate companies ... does not lead, either logically or as a practical matter, to a conclusion that the State is discriminating against interstate commerce" and accordingly runs afoul of the Dormant Commerce Clause); $c f$. Goldsmith \& Sykes, supra note 287 , at 806 (coming to a similar conclusion using a normative framework premised on economic efficiency).

293 Exxon Corp, 437 U.S. at 126 (concluding that a Maryland statute did not discriminate against interstate commerce because the statute did not give in-state dealers a competitive advantage over out-of-state dealers).

${ }^{294}$ See, e.g., Healy v. Beer Inst., 491 U.S. 324, 334 (1989) (stating that extraterritoriality is problematic due to the possibility that it would create "inconsistent obligations").

295 See Healy, 491 U.S. at 343 (holding that a Connecticut contemporaneous affirmation provision requiring out-of-state alcohol distillers to attest they were not selling alcohol at lower prices outside of Connecticut was unconstitutional); Brown-Forman Distillers Corp. v. N.Y. State Liquor Auth., 476 U.S. 573, 585 (1986) (holding that a prospective affirmation provision requiring alcohol distillers to post prices of alcohol to be sold in neighboring states during the upcoming month and prohibiting them from selling alcohol in New York for a price exceeding the price to be charged in other states violated the Commerce Clause); Baldwin v. G.A.F. Seelig, Inc., 294 U.S. 511, 521 (1935) (invalidating a law prohibiting New York milk distributors from purchasing milk in Vermont at lower than a fixed price New York milk producers could match); see also Kreimer, Law of Choice, supra note 5, at 496 ("[A]ll of the cases in which statutes have been invalidated have involved laws which in some sense could be characterized as economic protectionism or predation."). 
Corp., a plurality of the Court struck down a nonprotectionist Illinois statute due to its extraterritorial effects. ${ }^{296}$ Nevertheless, five years later in CTS Corp. v. Dynamics Corp. of America, ${ }^{297}$ the Supreme Court rejected the MITE plurality's reasoning and upheld a nonprotectionist statute that was virtually indistinguishable from what had been struck down in MITE, using a legal test that deployed lower-level scrutiny than the virtual per se rule. ${ }^{298}$ Thus, taking into account CTS's reworking of MITE, it is fair to say that under the current state of Dormant Commerce Clause law, the per se invalidation rule concerning extraterritoriality is invoked only with respect to protectionist statutes. The proposition that the per se rule is not applicable to nonprotectionist statutes accordingly is consistent with applicable precedent.

\section{c. Regulating noncitizens}

There is yet another possible distinction between the Dormant Commerce Clause extraterritoriality cases that have invoked the rule of per se invalidity and the issue of a Home State's power to regulate its citizens' out-of-state conduct. All the Dormant Commerce Clause cases have struck down statutes in which the extraterritorial regulations applied primarily to noncitizens of the regulating State. ${ }^{299}$ By contrast, the extraterritorial

296457 U.S. 624, 643 (1982). Indeed, a plurality of the Court appeared to hold in MITE that a state statute having a "direct restraint on interstate commerce" by imposing "sweeping extraterritorial effect[s]" is invalid under the Dormant Commerce Clause "regardless of the purpose with which it was enacted." Id. at 642 (internal quotations omitted).

297481 U.S. 69 (1987).

298 Both MITE and CTS concerned anti-takeover statutes in which the regulating state sought to regulate the purchase and sale of stock that occurred outside the state. The Illinois law struck down in MITE required that certain corporate takeover offers be registered with the Illinois secretary of state and gave her the power to refuse registration. MITE, 457 U.S. at 626-27. The Indiana law upheld in CTS required approval by a majority of preexisting shareholders when a potential buyer sought to acquire a substantial number of voting shares, even if neither the proposed purchase nor sale was to occur in Indiana. CTS, 481 U.S. at 7275; id. at 99-100 (White, J., dissenting). The CTS Court concluded that it was "not bound by [MITE's] reasoning" because MITE was a plurality opinion. Id. at 81 .

299 There is one Supreme Court case in which it is not clear whether the regulated party was a noncitizen of the regulating state, the 1935 case of Baldwin v. G. A. F. Seelig, Inc., 294 U.S. 511 (1935). In any event, this case is not inconsistent with the above text because the unusual statute in that case was patently protectionist. To protect New York's milk producers, the New York law precluded dealers from selling in New York milk they purchased out of state at less than the minimum price fixed by the statute. $I d$. at $519 \mathrm{n} .1$. Indeed, a fair reading of the opinion reveals that the Court's concern was not with extraterritoriality per se, but with how such a regulation could "set a barrier to traffic bet ween one state and another as effective as if customs duties ... had been laid upon the thing transported." Id. at 521. In other words, the Court's concern was with economic protectionism, and extraterritoriality was problematic only insofar as it had the protectionist "effect of establishing an economic barrier against 
regulations contemplated in this Article would be applied only to citizens.

The distinction between citizen and noncitizen has been critical in the cases. $^{300}$ This was the basis on which the CTS Court explained why there was no inconsistency between its upholding Indiana's anti-takeover statute and the MITE Court's striking down of Illinois' similar anti-takeover law. Under both laws, the regulating state sought to regulate purchases and sales of corporate stock that occurred outside its borders. ${ }^{301}$ The important distinction, according to the CTS Court, was that the Illinois law "applied as well to out-of-state corporations as to in-state corporations," whereas the Indiana Act "applie[d] only to corporations incorporated in Indiana." 302 Moreover, whereas the Illinois statute could have applied even where there were no Illinois shareholders, ${ }^{303}$ "the Indiana Act applies only to corporations that have a substantial number of shareholders in Indiana." ${ }^{304}$ Of partic ular significance to the issue of Home State power to regulate its citizens' out-of-state behavior, the Court upheld the statute in CTS because "every application of the Indiana Act will affect a substantial number of Indiana residents, whom Indiana indisputably has an interest in protecting, ${ }^{, 305}$ even though the out-of-state commercial activities of noncitizens also were regulated by the law. ${ }^{306}$ If the Dormant Commerce

compet ition with the products of another state or the labor of its residents." Id. at 527.

${ }^{300}$ I will not attempt in this Article to explain why this is an important distinction for purposes of the Dormant Commerce Clause (though I suspect it is best understood as being connected to protectionism insofar as representation reinforcement concerns may be less pressing in respect of state statutes that regulate both citizens and noncitizens). I am content to rest on formalistic legal argumentation here for two related reasons: (1) the Court's extraterritoriality strand of Dormant Commerce Clause jurisprudence is woefully undertheorized and arguably not internally consistent; and (2) this Article primarily provides positive rather than prescriptive and normative legal argumentation. Providing a theoretical account of the significance of citizenship for the Dormant Commerce Clause would, I believe, transform the analysis into prescriptive and normative argumentation. Goldsmith and Sykes's fine article, by contrast, is firmly a normative argument that is more willing to reject cases as having been incorrectly decided than is this Article.

301 See supra note 298 (outlining statutory provisions regulating extraterritorial sale of stock at issue in both MITE and CTS).

302 CTS, 481 U.S. at 93.

303 See MITE, 457 U.S. at 642 (noting that the Illinois statute "could be applied to regulate [takeovers] which would not affect a single Illinois shareholder").

304 CTS, 481 U.S. at 93.

305 Id.

306 The statute operated extraterritorially by requiring approval by a majority of preexisting shareholders when a potential buyer sought to acquire a substantial number of voting shares even if neither the purchase nor sale was to occur in Indiana. See Id. at 99-100 (White J., dissenting) (noting that "people from all over the country buy and sell CTS' shares daily" and that under the Indiana law "any prospective purchaser will be effectively precluded from purchasing CTS' shares if the purchaser crosses [a certain] threshold ownership level[] and a majority of CTS's shareholders refuse to give the purchaser voting rights"). 
Clause countenances extraterritorial regulation of noncit izens' commercial activities due to Indiana's "substantial interest[s]" in its citizens' primarily commercial activities, ${ }^{307}$ it would follow that the clause does not pose an insurmountable bar to a Home State regulating its citizens' out-of-state activities when those activities are primarily or exclusively noncommercial.

\section{d. Impermissible risk of inconsistent regulation}

This is not to suggest that the Dormant Commerce Clause poses no limitations regarding extraterritoriality in commercial contexts under CTS. But unlike the plurality opinion in MITE, under whose rationale extraterritoriality would appear to be per se unconstitutional, ${ }^{308}$ CTS introduced a lower level of scrutiny under which the relevant question is whether the state statute "may adversely affect interstate commerce by subjecting activities to inconsistent regulations." 309 The Indiana statute was not problematic, according to the CTS Court, because it is well-established that the state of incorporation regulates its domestic corporations, including shareholders' voting rights. ${ }^{310}$ Consequently, "each corporation will be subject to the law of only one State," and accordingly there is no "impermissible risk of inconsistent regulation by different States." 311

The types of regulations discussed in this Article would not lead to impermissible risks of inconsistent regulation for purposes of the Dormant Commerce Clause. The parentheticals provided by the CTS Court to gloss the cases to which it cites speak of "subjects that "are in their nature national, or admit only of one uniform system, or plan of regulation.","312 For example, the CTS Court referred to the "confusion and difficulty' that

307 Id. at 93.

308 See MITE, 457 U.S. at 642-43 (concluding that the Dormant Commerce Clause "precludes the application of a state statute to commerce that takes place wholly outside of the State's borders, whether or not the commerce has effects within the State").

309 CTS, 481 U.S. at 88. CTS thus substituted a more flexible test for MITE's bright line prohibition of extraterritoriality. The CTS Court explicitly stated that it was "not bound by [MITE's] reasoning" because it was only a plurality opinion. Id. at 81 . To be sure, one postCTS case, see Healy v. Beer Institute, 491 U.S. 324, 328 (1989) (stating that the Dormant Commerce Clause " "prohibit[s] the state from controlling the prices set for sales occurring wholly outside its territory", (quoting United States Brewers Ass'n v. Healy, 692 F.2d 275, 282 (2d Cir. 1982))), appears to have returned to MITE's approach to extraterritoriality, but Healy was a case that involved a state statute that was clearly protectionist, namely, Connecticut's contemporaneous affirmation provision that required alcohol distillers to attest they were not selling alcohol at lower prices outside of New York, where such heightened scrutiny is appropriate.

310 CTS, 481 U.S. at 89.

311 Id.

312 Id. at 88-89 (quoting Cooley v. Bd. of Wardens, 53 U.S. (12 How.) 299, 319 (1852)). 
would attend the 'unsatisfied need for uniformity' in setting maximum limits on train lengths" ${ }^{\prime 13}$ and similarly cited to a case that struck down a state law limiting permissible truck lengths that was "out of step with the laws of all other [neighboring] States., "314 The Court's discussion confirms that inconsistent regulations of a given activity are not per se unconstitutional. Indeed, to hold otherwise would be to dramatically circumscribe the states' regulatory powers; this is so because

[t]here is nothing unusual about nonuniform regulations in our federal system. States are allowed to make their own regulatory judgments about scores of issues. The mere fact that states may promulgate different substantive regulations of the same activity cannot possibly be the touchstone for illegality under the dormant Commerce Clause.

For example, states have different libel standards, tax regimes, and tort laws that might simultaneously be applicable to the same activity. ${ }^{316}$ The Dormant Commerce Clause wisely has not been held to disallow these types of inconsistent regulations. The caselaw suggests that inconsistent regulations are problematic for purposes of the Dormant Commerce Clause only if such inconsistencies threaten the free flow of interstate commerce; it is readily apparent that inconsistent state laws governing train or truck lengths might impose severe compliance costs that could make it effectively impossible for the regulated parties to engage in interstate commerce. ${ }^{317}$

The policy differences among the states of the sort contemplated in this Article are, however, not "subjects that "are in their nature national, or admit only of one uniform system, or plan of regulation.",318 Inconsistent state regulations of this sort accordingly do not violate the Dormant Commerce Clause. Just the opposite: under the Constitution, states are permitted to differ among themselves on such hotly contested matters as parental notification laws, gambling, motorcycle helmets, and the like, and extraterritorial regulation might be necessary to ensure the efficacy of these laws. The mere fact that applic ation of the Home State's law to its traveling citizens affects interstate commerce does not violate the Dormant Commerce Clause; as the Supreme Court has observed, "there is a residuum

313 Id. at 88 (quoting S. Pac. Co. v. Arizona, 325 U.S. 761, 774 (1945)).

314 Id. at 88 (quoting Kassel v. Consol. Freightways Corp., 450 U.S. 662, 671 (1981)).

315 Goldsmith \& Sykes, supra note 287 , at 806.

316 See id. at 804 (noting that multistate firms oft en encounter varying state laws governing taxes, libel, securities, etc.).

317 See id. at 807 (observing that the Supreme Court cases invalidating transportation safety regulations turn on the "judicial judgment that the regulatory benefits of [those regulations] were illusory while the costs of complying ... were severe").

318 CTS, 481 U.S. at 88-89 (quoting Cooley v. Bd. of Wardens, 53 U.S. (12 How.) 299, 319 (1852)). 
of power in the state to make laws governing matters of local concern which nevertheless in some measure affect interstate commerce or even, to some extent, regulate it. ${ }^{, 319}$ Our federal system contemplates that the states can have different political theories that animate their legislative decisions, and it would be a perversion of that system to treat such anticipatable nonuniformities as problematic, "inconsistent regulations" 320 that run afoul of the Dormant Commerce Clause.

\section{The Example of Dean Foods v. Brancel}

A recent federal appellate court decision mentioned above, ${ }^{321}$ Dean Foods Co. v. Brancel, ${ }^{322}$ provides an excellent test case for Dormant Commerce Clause analysis of a Home State's effort to regulate extraterritorially. The State of Wisconsin was concerned about the future of small dairy farmers in Wisconsin, having lost approximately 15,000 small dairy farms over a period of fifteen years. In addition to the economies-ofscale that large dairy farmers enjoyed, the large farmers had arrangements with milk processors (purchasers of raw milk from the farmers) under which the large farmers were paid premiums exceeding the processors' cost savings in procuring milk from large farmers. ${ }^{323}$ The Wisconsin Department of Agriculture did not seek to counteract the price differential attributable to the economies-of-scale and transaction costs savings of the large farms. But the Department deemed all payments by processors in excess of costs savings to constitute "unjustified" premiums and banned them. ${ }^{324}$ Wisconsin hoped the new regulation would put small Wisconsin dairy farmers on equal ground with large Wisconsin farmers without discounting the real economic benefits of large farming operations.

Dean Foods was an out-of-state milk processor that purchased milk from dairy farms in Wisconsin. Under long-standing practice, Dean Foods hired milk haulers to collect and transport milk from Wisconsin farmers. After the new regulation was enacted, however, Dean Foods "announced a new milk-purchasing program intended to circumvent" the ban on unjustified premiums. ${ }^{325}$ Under the new plan, Dean Foods allowed Wisconsin farmers to contract directly with haulers to transport their milk to

\footnotetext{
319 Kassel v. Consol. Freightways Corp., 450 U.S. 662, 669 (1981)

320 For a similar point, see Regan, supra note 27, at 1884-85.

321 Supra text accompanying note 12.

322187 F.3d 609 (7th Cir. 1999).

323 Id. at 611 .

324 Id.

325 Id. at 612.
} 
Dean Foods' facilities in Illinois. Transfer of title technically occurred in Illinois under the new plan, and Dean Foods accordingly concluded that Wisconsin's regulation would not apply. Under the plan, Dean Foods continued to pay to large dairy farmers the premiums that had been deemed "unjustified" and banned by Wisconsin. The Wisconsin Department of Agriculture, however, attempted to apply its regulation to milk purchased under the new plan, given Wisconsin's many connections with the transaction. At issue in the case was whether Wisconsin had the power to do this.

The Seventh Circuit concluded that the transactions under the new plan were beyond Wisconsin's regulatory powers. The Seventh Circuit acknowledged that the sales under the new plan "ha[d] an effect that is felt, perhaps even predominantly, in Wisconsin" given the "reality that these sales involve[d] Wisconsin farmers and Wisconsin milk." 326 The court nonetheless ruled that Wisconsin could not regulate the sales because they occurred in Illinois, citing MITE and Healy for the proposition that one State cannot "regulate commerce which occurs outside of its jurisdiction." $" 327$

The Dean Foods analysis is problematic. Although the regulation at issue in Dean Foods makes for a harder case under the Dormant Commerce Clause than most of the other Home State extraterritorial regulations analyzed in this Article because it was a regulation that concerned commerce, even this type of regulation should be permitted. To begin with, it is important to recognize that Dean Foods fits the paradigm of a Home State seeking to regulate its citizens' out-of-state conduct for the purpose of ensuring that domestic policies are not circumvented by mere travel: The Home State of Wisconsin was taking steps to ensure that its citizens-the large dairy farmers - did not circumvent Wisconsin regulations that were directed at securing a certain result in Wisconsin - helping to maintain small dairy farms. ${ }^{328}$

326 Id. at 619.

327 Id. at 619-20.

328 The regulation varied from the paradigm on account of the fact that the party whose actions were the subject of the regulation was a noncitizen; the regulation barred milk processors from paying the premiums. One state's effort to regulate the extraterritorial conduct of noncitizens presents a greater constitutional hurdle than a Home State's efforts to regulate its own citizens. Nonetheless, this aspect of the Wisconsin regulation readily could have been altered without interfering with the regulation's functional efficacy; the regulation could have proscribed large dairy farmers from accepting the banned premiums. Such a modification of the regulation would not have saved the regulation under the Seventh Circuit's understanding of the Dormant Commerce Clause, however, for the regulated sale still would have occurred outside of Wisconsin. See id. at 619-20 ("[T]he fact that a particular transaction may affect or impact a state does not license that state to regulate commerce which 
Under the Seventh Circuit's analysis, the Dormant Commerce Clause prevented Wisconsin from making certain that its police power interests were not circumvented by mere travel. The Dean Foods Court was wrong to subject Wisconsin's regulation to a per se rule of extraterritorial unconstitutionality under the Dormant Commerce Clause, however, because the regulation was not a species of economic protectionism. Indeed, if anything, the regulation disadvantaged Wisconsin farmers vis-à-vis out-ofstate farmers by making the produce of large farmers more expensive than it otherwise would have been. ${ }^{329}$ The appropriate test, instead, was CTS's lower-level risk-of-inconsistent-regulations analysis. ${ }^{330}$

Wisconsin's regulation should have been sustained under such review for two reasons. First, the Wisconsin regulation was not inconsistent with any Illinois law nor was an Illinois statute imposing conflic ting duties on milk producers "readily imagin[able].",331 Second, the subject of the regulation - a prohibition on payments in excess of cost savings for the purpose of putting small farmers on more equal grounding with large farmers-is not the type of matter about which there must be national uniformity. Nonuniformity across states about such matters of economic and social theory wisely is permitted under our federal system.

occurs outside its jurisdiction.").

329 Although the Seventh Circuit observed that "[a]nother apparent reason for the ban on these premiums is that smaller in-state processors are less likely to be able to pay them," id. at 611 , this appeared to be an ancillary goal of the regulation, see id. (stating that the secretary promulgated the regulations to stem the tide in which Wisconsin had lost "roughly 15,000 dairy farmers in the past 15 years"). More importantly, there was no suggestion that this functioned to the sle disadvantage of out-of-staters, a necessary element of economic protectionism. See Exxon Corp. v. Governor of Md., 437 U.S. 117, 126 (1978) ("The absence of any of these factors fully distinguishes this case from those in which a State has been found to have discriminated against interstate commerce.").

330 Unlike the district court opinion, Dean Foods Co. v. Brancel, 22 F. Supp. 2d 931 (W.D. Wis. 1998), the Seventh Circuit did not wholly overlook CTS. The State of Wisconsin, however, "ma[de] no mention of the 'inconsistent regulations' strand of dormant Commerce Clause doctrine," and the Seventh Circuit accordingly treated any arguments under CTS as having been waived. Dean Foods, 187 F.3d at 616. This does not excuse the Seventh Circuit's analysis, however, because a party's failure to raise the applicable doctrine does not give a court license to analyze the legal questions by means of inapplicable law. Furthermore, the Dean Foods court in dicta suggested that CTS's rule might be limited to the context of corporations law, see id. at 615 ("CTS may be distinguishable from most other extraterritoriality cases because it dealt with corporations, which are uniquely creations of state law."), and inclined toward the view that the Dormant Commerce Clause otherwise provides a per se prohibition against extraterritorial regulation, see id. at 616-17 ("[E]xtraterritoriality principles ban a state from regulating 'sales that take place wholly outside it."' (citation omitted)).

331 Head v. N.M. Bd. of Exam'rs in Optometry, 374 U.S. 424, 427-29 (1963). 


\section{Structural Constitutional Considerations}

Two prominent scholars, Professor Lea Brilmayer and Professor Seth Kreimer, have argued that structural constitutional considerations place severe limits on Home States' powers to regulate the out-of-state conduct of their citizens. ${ }^{332}$ With all due respect, I do not believe that their arguments withstand careful scrutiny.

\section{Exclusive Territory-Based Jurisdiction in Respect of Policies About Which There Are Sharp Moral Disagreements Among States}

Professor Lea Brilmayer has sought to ground limitations on the Home State's powers to regulate its citizens' out-of-state conduct in structural constitutional considerations. ${ }^{333}$ She has concluded that with respect to issues about which there are sharp moral disagreements among states, such as abortion and the right to die, "the structure of our federal system clearly compels the priority of the territorial state, and ... this priority typically invalidates the residence state's claim to regulate." ${ }^{334}$ Her argument is beguilingly simple. Where two states' laws purport to govern a transaction or occurrence and the laws directly clash, there must be a method to prioritize the laws so as to determine which one applies. Professor Brilmayer concludes that "territoriality trumps residence" 335 in most cases of direct clash between state policies, ${ }^{336}$ including abortion (such as when

\footnotetext{
332 Professor Donald Regan also concludes that structural considerations limit states' extraterritorial powers, but the bulk of his discussion concerns state efforts to regulate noncitizens. Regan, supra note 27, at 1884-1913. Though his remarks are self-consciously preliminary, see, e.g., id. at 1887 ("I shall discuss some specific extraterrit oriality problems, actual and hypothetical - not with an eye to presenting a general theory, but in the hopes of encouraging someone else to try to develop one."), he comes to provisional conclusions that are consistent with this Article, see id. at 1896 (noting the "possibility that states may be able to legislate extraterritorially where their own citizens are concerned"); id. at 1909 ("[T]o say that one can always abandon one's state and its laws by changing one's citizenship is not to say that one can take a holiday from the state's laws, while remaining a citizen by sojourning elsewhere.")

${ }^{333}$ See Brilmayer, supra note 26, at 875 (making clear that her position is that a "prolife state's attempt to prohibit abortions extraterritorially" when its citizen is located in a state that "desire[s] to ensure freedom of choice" would be "constitutionally invalid"); id. at 881 (noting that her article "assess[es] the constitutionality of concurrent jurisdiction").

334 Id. at 876.

$335 I d$. at 884 . Professor Brilmayer uses the term territoriality in the same way that I use the term "Host State."

336 Professor Brilmayer helpfully notes the distinction between state policies of "indifference" to an activity and "license" of that activity, and observes that "indifference" cannot be inconsistent with another state's affirmative desire to prohibit the activity. Id. at 888,892 . In other words, differences in respect of what activities are permitted by different states do not necessarily give rise to "direct clashes" between the states' laws. $I d$. at 876 .
} 
the Home State, but not the Host State, has parental notification laws), because "pro-life states are undoubtedly unwilling to give up the right to regulate abortions within their own borders. If the residence of the woman [determined which law applied] . . then pro-life states would have to allow nonresident women to have abortions in local medical facilities." ${ }^{337}$ Because they do not, Brilmayer concludes that pro-life Home States are likewise without power, as a matter of federal constitutional law, to regulate the out-of-state conduct of their own citizens in respect of matters such as abortion and the right to die. ${ }^{338}$

Professor Brilmayer's argument is premised on two problematic propositions. The first is that some structural and, apparently, constitutional principle $^{339}$ compels there to be a single "connecting factor" that determines which state's law applies with respect to matters about which states are deeply divided. $^{340}$ The second is that the Host State's regulation trumps the Home State's when the two directly clash.

\section{a. The problematics of a single "connecting factor"}

First let us consider Professor Brilmayer's argument that a structural constitutional principle compels that there be a single "connecting factor" that determines which state's law applies with respect to matters about which states are deeply divided. This is the foundation of her contention that a pro-life state that wished to regulate its citizens' out-of-state conduct has opted for a residence principle that acordingly requires it to permit visitors from pro-choice states to be governed by their Home State's laws during their travels. Under Professor Brilmayer's analysis, the pro-life

337 Id. at 886. Professor Brilmayer provides a second justification, that "[r]esidencebased regulation is problematic where a single rule must decide the legal rights of more than one person, because the individuals may hail from different states." $I d$. at 885 . She acknowledges that this difficulty can be readily eliminated if the Home States relinquish claims to regulate noncitizens (such as the doctors in the out-of-state hospital). Id. at 885-86. Accordingly, the only justification for the proposition that territoriality trumps residence that remains for present purposes (where I consider only Home State powers to extraterritorially regulate its own citizens) is Professor Brilmayer's second explanation, which is analyzed above in the text. Nonetheless, because a Home State's ability to regulate its citizens' out-ofstate conduct conceivably could be aided were it to have the power to regulate noncitizens who abetted the cit izens, I hope to pursue the other justification at greater length in the future.

338 See id. at 889 (noting that her approach seeks to "prioritiz[e] the various connecting factors" and "singl[e] one out as constitutionally sufficient" so as to identify only one state as having legislative jurisdiction).

339 See supra notes 333, 338 (noting that concurrent jurisdiction is constitutionally invalid in many contexts and that a constitutionally sufficient connecting factor would solve this problem).

${ }^{340}$ Brilmayer, supra note 26 , at $886-88$ (explaining the application of the "connecting factor" in the abortion context). 
Home State that will not allow visitors from pro-choice states to have abortions within its borders has rejected residence as the single connecting factor and accordingly cannot invoke residence as a basis for regulating its own citizens' out-of-state conduct. ${ }^{341}$

Professor Brilmayer does not provide a legal source for the supposedly constitutional principle that a single connecting factor determines which single state has the power to regulate in circumstances of direct clash between state regulatory regimes. ${ }^{342}$ This is because there is no legal source for the proposition. Indeed, a close look at Professor Brilmayer's carefully phrased argument confirms that this all-important principle is hypothetical: "if we are to eliminate concurrent jurisdiction by singling out a unique, constitutionally adequate connecting factor," then, she concludes, at least in the abortion context, territoriality should trump residence. ${ }^{343}$ This formulation accurately reflects the fact that identifying a single factor for purposes of choice of law is not a requirement of contemporary constitutional or choice-of-law doctrine, a fact that Professor Brilmayer herself explicitly notes elsewhere. ${ }^{344}$ The Supreme Court has not ruled that the Constitution requires a particular choice-of-law methodology. Indeed, the Court recently upheld a state choice-of-law methodology that takes account of multiple factors, ${ }^{345}$ as the Restatement (Second) of Conflicts itself does. ${ }^{346}$

What undergirds Professor Brilmayer's "single factor" proposition is not precedent, but a policy argument. ${ }^{347}$ Her argument is in two steps. First, concurrent jurisdiction is "unworkable" in contexts of "direct clash" between two or more states. ${ }^{348}$ Second, a noncategorical "case-by-case

341 See id. at 888 (stating that a single connecting factor, such as residence or territoriality, has to be chosen "to divide the spheres of regulation fairly and equally between the contending states").

${ }^{342}$ See id. at 886-89 (stating that a constitutionally sufficient connecting factor is necessary to settle the conflict, but not explicating the derivation of that principle)

343 Id. at 886 (emphasis added).

344 See id. at 877 ("No single connecting factor uniquely validates the forum's claim to apply its law; different contacts are relevant in different sorts of cases.").

345 See, e.g., Allstate Ins. Co. v. Hague, 449 U.S. 302, 313-20 (1981) (upholding the application of Minnesota hw on the basis of three factors: nominal residence; state-party contacts; and state locus of the occurrence contacts).

346 See Restatement (SECOND) OF CONFLiCt OF LAWs § 6 (1969) (listing seven factors for the courts to consider in choosing the applicable rule of law).

347 See Brilmayer, supra note 26, at 884-85 (exploring the implications of a residencebased, territory-based, and case-by-case assessment system of determining problems of concurrent jurisdiction).

${ }^{348}$ See id. at 883-84 ("The constitutional limits on concurrent jurisdiction .... turn on whether policies directly clash ...."). 
assessment" of which state's law ought to be given effect is problematic because the uncertainty it would create would allow potential defendants to protect themselves only by conforming to the more restrictive state's laws, thereby "violating the principle of sovereign state equality." ${ }^{349}$ Therefore, concludes Professor Brilmayer, an easily applied rule that looks to only one factor to determine which state has legislative jurisdiction is necessary. ${ }^{350}$ (She argues that the Host State's laws should categorically prevail, a matter which I discuss at some length in the next Subsection; this Subsection, it should be recalled, is concerned solely with the propriety of adopting a single factor test to determine which state has legislative jurisdiction.)

I do not believe that Professor Brilmayer's two-step argument is persuasive. To begin, Professor Brilmayer is not clear about when concurrent jurisdiction is "unworkable" (such that the entire exercise of eliminating one state's power to regulate must be initiated). At one point in her article she discusses the Supreme Court's "inconsistent regulations" jurisprudence under the Dormant Commerce Clause, ${ }^{351}$ but she does not explain why regulations in respect of abortion or the right to die would run afoul of this body of law. Indeed, I suggested above why such regulations would not qualify as problematic "inconsistent regulations.",352 Although such state regulations do have an impact on interstate commerce, they are primarily concerned with paradigmatic exercises of police power in pursuit of health and welfare-not protectionism-and they are directed at the enacting state's own citizens. Further, the regulated subjects are not matters about which national uniformity is necessary to preserve interstate commerce. Just the opposite: having diverse approaches among the states to such hotly contested matters that the Federal Constitution does not resolve is precisely where heterogeneity across states is most important.

As suggested above, however, Professor Brilmayer's understanding of unworkability may not be directly tied to precedent (in this case, the precise contours of the Dormant Commerce Clause doctrine). Instead, her notion of unworkability appears to be connected to more general policy principles relating to personal protections and constitutional structure. If this is so, her argument would not be vulnerable to the accusation that it is inconsistent

${ }^{349} I d$. at 885 . As will be shown below in the text, these two steps are actually interrelated.

${ }^{350}$ See id. ("This leaves us with a choice between allowing the residence state to regulate and allowing the terminal state to regulate.").

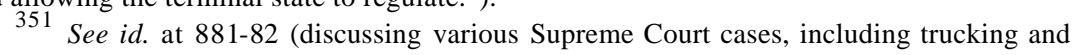
state takeover cases, in which several states might impose inconsistent requirements on interstate activities).

352 See supra notes 312-20 (arguing that inconsistent regulations only violate the Dormant Commerce Clause if the inconsistencies threaten interstate commerce). 
with contemporary doctrine insofar as her argument would be premised on prescriptive and normative claims rather than positive description of what the law is. ${ }^{353}$ The force of her position would then turn not on its consistency with precedent, but on the strength of its policy argument.

Even under this criterion, however, Professor Brilmayer's argument that concurrent jurisdiction is unworkable in respect of polic ies about which states are deeply divided does not fare well. The policy arguments she makes - based on personal protections and constitutional structure-are interconnected. She claims that if one state "expressly licensed what the other prohibited, potential defendants could protect themselves only by conforming to the more restrictive rule. This outcome would consistently subordinate the licensing policy of the first state, violating the principle of sovereign state equality." 354 Consider first Professor Brilmayer's personal protections argument. Two things can be said in response to the assertion that "potential defendants could protect themselves only by conforming to the more restrictive rule." 355 First, this is surely an overstatement, for potential defendants will have to conform to the more restrictive rule only when their Home State wishes to regulate their out-of-state activities; when the Home State is only concerned with what its citizen does in the state, the visitor can be governed exclusively by the Host State's law.

Second, even when the Home State does wish to regulate its citizens extraterritorially, the fact that the visitor must conform to the more restrictive rule is not necessarily a bad thing. In fact, it is merely the other side of the coin of not allowing citizens to escape their Home State's legal obligations by merely traveling to more permissive states. Thus, observing that visitors will have to conform their behavior to the more restrictive legal regime $^{356}$ does not answer the normative arguments advanced above as to why a Home State should have continuing power over its traveling citizens if it so wishes. ${ }^{357}$ If, as argued above, it is better that Home States have the power to ensure the efficacy of policies they are constitutionally entitled to

353 See Jolls et al., supra note 178, at 1474-75 (providing a clear explanation of the relationship between positive, prescriptive, and normative analysis).

354 Brilmayer, supra note 26 , at 884-85.

355 Id. at 884 .

356 The analysis is no different in the converse case of a traveler from a more lenient Home State visiting a restrictive Host State. There is no basis for concluding that the Host State's law should be overridden; for the reasons discussed below, our country's federal system is characterized by presumptive concurrent jurisdiction, so the Host State's restrictive rule presumptively would apply to the visitor. See infra Part III (supporting the argument that the legal system functions under a concurrent regulatory jurisdiction regime).

357 See supra Part I.C.3 (arguing that the power to regulate extraterritorially ensures the efficacy of constitutional state policies and protects political heterogeneity among states). 
pursue--a power that supports political heterogeneity across states ${ }^{358}$ - then requiring visitors to conform to the Home State's more restrictive law, when a Home State so desires, is normatively good. The fairness of this conclusion can be illustrated by conducting the Rawlsian thought experiment discussed above under which people are asked to try to step away from their current commitments by imagining what political structure they would choose if they did not know who they actually were. Such a thought experiment leads to the conclusion that a political system in which Home States have the power to regulate their citizens' out-of-state conduct, if they so wish, is the most fair political structure. ${ }^{359}$ It would follow that it is not unfair to require a person to conform to her Home State's laws insofar as she ex ante would agree that it is fair to create a political structure in which Home States have such extraterritorial powers.

Consider next Professor Brilmayer's structural argument that a single connecting factor is necessary to protect the principle of "sovereign state equality." Her claim is that permitting the Home State's regulations to apply would systematically "subordinate the licensing policy of the first state," thereby "throw[ing] the licensing state's policy to the wolves." This argument is unconvincing. To begin with, it is hyperbolic. Far from being thrown to the wolves, the Host State's licensing policy still would be applicable to its own citizens and to visitors from states that elect not to regulate their citizens' out-of-state activities. In fact, under Professor Brilmayer's solution, it is the Home State's laws that systematically would be "subordinated" and "thrown to the wolves," for allowing the Host State's law to categorically trump the Home State's law would render the latter's policy open to wholesale circumvention in respect of many types of laws. ${ }^{361}$ Furthermore, it is highly dubious whether a state's extraterritorial regulation of its citizens even implicates the issue of "sovereign state equality" in the first place. Assumed without explanation in Professor Brilmayer's argument is that a valid aspect of state sovereignty is the power to regulate the behavior of the Home State's citizens against the Home State's wishes when the bulk of the consequences of the visitor's activity will be felt by the

\footnotetext{
358 See supra Part I.C.3.b (positing that the possibility of extraterritorial regulation expands political heterogeneity by allowing states to impose paternalistic and norm-driven legal constraints that cannot be evaded by travel, which would render the regulations ineffectual).

359 Id. (arguing from the premise that the fairest political structure is one that accommodates a broad range of lifestyle choices, including those who require a political structure that allows extraterritorial regulation).

360 Brilmayer, supra note 26, at 885 .

361 See supra Part I.C.3.a (discussing how extraterritorial regulation is fair because it ensures the efficacy of constitutional state policies).
} 
Home State. My hunch is that many would think that regulating the behavior of noncitizens, against the wishes of the Home State, falls outside the proper domain of the Host State's legislative jurisdiction in the first place. ${ }^{362}$ If that is so, then permitting the Home State's regulations to trump does absolutely no violence to sovereign state equality.

Moreover, the conclusion that sovereign state equality is not at issue can still hold even if the Host State is deemed to have some interest in regulating visitors. If the Home State's interest in its peripatetic citizens' particular activity is greater than the Host State's, then permitting the Home State's interest to prevail in no way threatens the principle of sovereign state equality. The Host State and the Home State would be understood to be differently situated vis-à-vis the visitor, and permitting the Home State's regulation to trump when the bulk of effects will be felt at home would not undermine state equality.

Indeed, it is Professor Brilmayer's solution that could be said to threaten sovereign state equality. Disallowing Home States from regulating their traveling citizens would undermine the principle of sovereign state equality insofar as it would allow Host States to interfere with the relationship between the Home State and its citizens by permitting Host States to serve as havens from restrictive Home State laws. This would significantly undermine the state sovereignty of certain types of states-in particular, those that favor government regulation and those states that are communitarian-minded-by preventing them from ensuring the efficacy of their policies. ${ }^{363}$ By systematically disfavoring states that have a proclivity toward regulation, Professor Brilmayer's solution accordingly could be said to violate state sovereign equality.

Finally, it is worth noting that the twentieth century's experience with the field of conflict of laws may well have something to teach about the need to resist the impulse of attempting to make choice of law turn on a single factor. The last doctrinal system that attempted to resolve choice-oflaw disputes by means of a single connecting factor-Professor Beale's "vested rights" approach, a largely territory-driven system under which the activity was governed by the law of the place where the last aspect of the activity occurred-has been almost universally recognized as a failure. ${ }^{364}$ Since its rejection, virtually no courts or commentators advance choice-of-

362 Cf. CTS Corp. v. Dynamics Corp. of Am., 481 U.S. 69, 93 (1987) ("We agree that Indiana has no interest in protecting nonresident shareholders of nonresident corporations.").

363 Supra Part I.C.3.a.

364 See, e.g., SCOLES ET AL., supra note 124, at 20-25 (arguing that the "vested rights" approach is too rigid and mechanical and noting that many critics have recognized these deficiencies). 
law rules under which a single factor alone determines the applicable law. ${ }^{365}$ Indeed, most choice-of-law scholars have concluded from the experience of the last century that any successful choice-of-law system inevitably must be highly nuanced and case-sensitive. ${ }^{366}$ Professor Brilmayer's singleconnecting factor approach runs against the weight of scholarly consensus in this respect. ${ }^{367}$

Indeed, there are solid theoretical reasons to believe that attempting to solve the conflicts problem in the context of deeply divisive policies by isolating a single factor of either territoriality or residence would be deeply problematic. Gains in ease of application of such a rule would be offset by the costs of the precarious outcomes that such a bright-line rule would create. The fundamental trouble with such an approach is that both residence and territoriality are crucial aspects of political community and state sovereignty. To arbitrarily select one as per se trumping the other would do serious violence to the political community's and sovereign state's welfare, crucial considerations that any choice-of-law methodology must take into account. Instead, a more nuanced, case-specific approach is necessary.

To quickly conclude, there is little to support Professor Brilmayer's argument that, as a matter of federal constitutional law, a single connecting factor must determine which single state's law is applicable when two (or more) states' laws directly clash. The caselaw does not support such a principle. Furthermore, a careful look at the policy arguments grounded in personal and structural protections does not counsel in favor of such a principle. And as will be seen below in Part III, many of Professor Brilmayer's "unworkability" concerns are addres sed not by a single categorical rule under which the Host State trumps, but by the interplay of four constitutional provisions. To be sure, obtaining the result under this rule of interplay is more complex than Professor Brilmayer's simple, formulaic rule. Nonetheless, simplicity is not always the best solution.

\footnotetext{
365 See id. at 22-102 (tracing the development of conflict-of-laws approaches following Beale's vested rights theory and concluding that the traditional, single connecting factor approach has been ultimately rejected in favor of methodologies that consider multiple factors); Kramer, supra note 29, at 1992-97 (providing a useful overview of modern conflictof-law approaches, all of which eschew solutions that turn on one connecting factor).

366 See, e.g., Goldsmith, supra note 95, at 1233 ("One lesson of this century's many failures in top-down choice-of-law theorizing is that choice-of-law rules are most effective when they are grounded in and sensitive to the concrete details of particular legal contexts.").

367 Professor Brilmayer's approach is properly conceptualized as a conflict-of-law rule similar to Beale's principle, which resolved the question of which law applies by identifying only one state as having legislative jurisdiction. See generally Roosevelt, supra note 218, at 2455-58 (noting this aspect of Beale's system).
} 
Indeed, nuance and complexity are necessary here to accommodate fairly the various states' and parties' interests.

\section{b. The problematics of categorically subordinating the Home State's} interests

Even if a single connecting factor did determine which state's law should apply under circumstances of direct clash, there are powerful structural reasons for concluding that the social policies that states are most acutely divided over are the very policies about which the Home States' regulations should trump the Host States'. The political heterogeneity made possible by federalism is most important precisely in respect of those policies not proscribed by the Federal Constitution and about which the states are most heatedly divided. To permit territoriality to categorically trump residence would undermine the political heterogeneity that our constitutional federal system allows and the experimentation across states it makes possible. ${ }^{368}$ By definition, it would create a political structure under which citizens of any state could always avail themselves of the least restrictive law of any of the states, foreclosing the possibility of having states whose systems do not permit their citizens to effectively opt nto a different legal regime merely by crossing a border.

By making the most permissive state's law a ready option for all United States citizens regardless of which state they are citizens, Professor Brilmayer's approach of allowing the Host State's rules to trump would systematically bias public policies toward the most permissive laws in the country. This would sabotage constitutionally permissible state efforts to achieve paternalistic and norm-shaping ends. It would also be particularly costly to the communitarian-minded, who believe that law plays a vital role in shaping the character of the citizenry, that citizens' values and behaviors are shaped by the behaviors of their neighbors regardless of where the behaviors ocur, ${ }^{369}$ and that the law accordingly must be concerned with citizens' out-of-state activities. In short, the potential for political heterogeneity is one of federalism's great benefits, and averting its dilution constitutes a structural reason for concluding, contrary to Professor Brilmayer, that Home States ought to have the power to extraterritorially regulate their citizens in respect of social policies over which the states are deeply divided. ${ }^{370}$

368 Supra Part I.C.3.b.

369 See, e.g., Kahan, supra note 132, at 356-59 (discussing the impact of social influence on people's values and behaviors).

${ }^{370}$ As is made clear below, this does not mean that the Home State's law should trump 
The proper solution to interstate conflict is a less categorical approach that takes account of both the Home and Host States' interests by recognizing that both states ordinarily have concurrent jurisdiction, even where their policies directly clash. To be sure, this solution is less streamlined than Professor Brilmayer's, but that is all right: There is no constitutional basis for prematurely tidying the field by categorically stripping one state (under Professor Brilmayer's approach, the Home State) of legislative jurisdiction over traveling citizens, and the costs of creating such a basis would be prohibitive. Part III explores in some detail how our country's system of concurrent jurisdiction operates and provides a preliminary explanation as to why it is not "unworkable."

\section{Exclusive State Sovereignty over Conduct Within a State's Borders}

Professor Kreimer also has argued that structural constitutional considerations severely constrain the extraterritorial powers of Home States. $\mathrm{He}$ asserts that " $[\mathrm{t}] \mathrm{he}$ American Constitution acknowledges exclusive state sovereignty over conduct within the territories defined by state borders.",371 The support for this claim is that "[m]any aspects of the constitutional structure would make no sense otherwise. ${ }^{372}$ The constitutional provisions to which he cites, however, are fully consistent with a structure of concurrent jurisdiction between or among interested states. Moreover, Professor Kreimer's analysis overlooks the many aspects of our jurisprudence-including, most importantly, the Double Jeopardy Clause's dual sovereignty doctrine-that reflect the fact hat ours is a system of presumptive concurrent legislative jurisdiction, not "exclusive," territorybased jurisdiction.

To begin, the constitutional provisions that Professor Kreimer cites do not compel the conclusion of exclusive territory-based jurisdiction, but are fully consistent with a regime of concurrent jurisdiction. Professor Kreimer is correct that " $[t]$ he understanding that a citizen of one state who ventured into another state would be bound by the local law was the premise for the adoption of Article IV's Privileges and Immunities Clause."373 The need animating the clause, ensuring that the Host State does not discriminate against out-of-staters, says nothing, however, about whether the Home State retains legislative jurisdiction. In other words, the Privileges and

the Host State's regulation as a per se matter; there would be great costs to such a categorical rule. The point here, though, is to showcase the profound structural costs that Professor Brilmayer's categorical approach would create.

371 Kreimer, Whoever Treasures Freedom, supra note 49, at 922 (emphasis added).

372 Id.

373 Id. 
Immunities Clause is perfectly consistent with a regime of concurrent jurisdiction.

Professor Kreimer next points to Article IV's Extradition Clause, which provides that an accused who flees from the state where a crime is committed is to be "delivered up[] to be removed to the State having Jurisdiction of the Crime.,"374 Although Professor Kreimer believes that this clause "acknowledges that the sole responsibility and prerogative for punishment rests with the state within which the crime occurred, ${ }^{375}$ the clause does no such thing. It simply refers to the "State having Jurisdiction of the Crime" without specifying the criteria that establish jurisdiction. Since Michigan has criminal jurisdiction over a person who engaged in bribery and false pretenses in Illinois as part of a scheme to fraudulently sell used machinery to the State of Michigan, ${ }^{376}$ the State of Michigan could successfully invoke the Extradition Clause if the accused fled back to Illinois after having entered Michigan subsequent to the crime. In short, because the presence of legislative jurisdiction turns on a host of due process-type considerations and not simply the actor's territorial presence, ${ }^{377}$ the Extradition Clause cannot be said to "make . . sense" only if there is "exclusive state sovereignty over conduct within the territories defined by state borders.",378

Finally, Professor Kreimer points to the Article IV provision under which the federal government agrees to protect each state against "Invasion" and to provide assistance to states against "domestic Violence" at their request. ${ }^{379}$ While this indeed indicates that territorial borders are of constitutional consequence, and while several other provisions similarly establish the constitutional significance of state borders, ${ }^{380}$ these provisions provide no support for the thesis that there is exclusive jurisdiction based on

374 U.S. CONST. art. IV, § 2, cl. 2.

${ }_{375}$ Kreimer, Whoever Treasures Freedom, supra note 49, at 922.

376 See Strassheim v. Daily, 221 U.S. 280, 285 (1911), discussed supra Part I.A, explaining that states are permitted to punish behavior "done outside a jurisdiction, but intended to produce and producing detrimental effects within it."

377 See supra Part I.C (arguing that legitimate state interests may, consistent with the Due Process Clause, justify legislative jurisdiction over persons when they are outside of a state's border).

378 Kreimer, Whoever Treasures Freedom, supra note 49, at 922.

379 U.S. CONST. art. IV, § 4, discussed in Kreimer, Whoever Treasures Freedom, supra note 49 , at 923 .

380 See, e.g., U.S. CONST. art. IV, $\$ 3$ (giving Congress the power to create state borders). See generally Douglas Laycock, Equal Citizens of Equal and Territorial States: The Constitutional Foundations of Choice of Law, 92 ColuM. L. REV. 249, 315-20 (1992) (discussing the constitutional significance of state borders in the allocation of governmental authority). 
territory. The mere fact that the federal government will dispense assistance in combating domestic violence or border incursions says nothing about the scope of one state's legislative jurisdiction.

Perhaps most importantly, Professor Kreimer's thesis that "[t]he American Constitution acknowledges exclusive state sovereignty over conduct within the territories defined by state borders,381 ignores entrenched practices and constitutional doctrines that testify to the existence of concurrent jurisdiction. To begin with, "exclusive" state sovereignty does not occur very frequently; rather, in most situations more than one state is permitted to, in effect, regulate a given activity. For example, a manufacturer in Michigan can be subject to both Kansas's and New Jersey's products liability law. ${ }^{382}$ Similarly, the National Enquirer is subject to both California's and Pennsylvania's defamation law. ${ }^{383}$ Consider as well the dual sovereignty doctrine: "When a defendant in a single act violates the 'peace and dignity' of two sovereigns by breaking the laws of each, he has committed two distinct 'offences" " and may be prosecuted by both states. ${ }^{384}$ More generally, as the earlier discussion of due process establishes, what matters doctrinally for purposes of legislative jurisdiction is not physical location per se, but whether the state has a legitimate interest. ${ }^{385}$ Though the state's interest frequently is triggered when events occur within its borders, territorial presence is not a prerequisite. For this reason, legislative jurisdiction is not tied to territory. Because more than one state may have a legitimate interest in a particular matter, more than one state may regulate it. The next Part of this Article elaborates the law that establishes and regulates our country's system of concurrent jurisdiction.

\section{OUR SySTEM OF CONCURRENT JURISDICTION}

As shown in Parts I and II, states have the presumptive power under due process and consistent with the Tenth Amendment to extraterritorially

381 Kreimer, Whoever Treasures Freedom, supra note 49, at 922 (emphasis added).

382 See McKernan v. Gen. Motors Corp., 3 P.3d 1261 (Kan. 2000) (holding that a products liability claim against General Motors was not barred by Kansas's 'Firefighter's Rule”); Poliseno v. Gen. Motors Corp., 744 A.2d 679 (N.J. Super. Ct. App. Div. 2000) (clarifying General Motors' liability under the crashworthiness products liability doctrine developed in New Jersey courts).

383 See Gilbert v. Nat'l Enquirer, 55 Cal. App. 4th 1273, 1275 (1997) (noting a defamation action against the National Enquirer based on California law); Dominiak v. Nat'l Enquirer, 266 A.2d 626, 627 (Pa. 1970) (noting Pennsylvania libel action against the National Enquirer based on Pennsylvania law).

384 Heath v. Alabama, 474 U.S. 82, 88 (1985) (quoting United States v. Lanza, 260 U.S. 377, $382(1922))$.

385 Supra Part I. 
regulate their traveling citizens, and no other constitutional provisions categorically limit this power. The Host State also typically has extensive legislative jurisdiction over visitors from other states. The result is a system of concurrent jurisdiction under which both the Home and Host States typically have simultaneous power to regulate. This Part shows as a matter of positive law that there is in fact a concurrent regulatory jurisdiction regime in place - a feature of our federal system that has eluded some noted commentators. This Part also provides a prolegomenon of why concurrent jurisdiction generally functions smoothly. ${ }^{386}$ Although primarily an exercise in positive law, Part III also identifies select aspects of the current doctrine that merit reconsideration, particularly in the light of this Article's earlier conclusions concerning the extent of Home State extraterritorial powers.

\section{A. The Fact of Concurrent Regulatory Jurisdiction}

One might be tempted to suggest that the claim that there is concurrent regulatory jurisdiction is belied by the constitutional provision that requires that "Full Faith and Credit shall be given in each State to the public Acts, Records, and judicial Proceedings of every other State. ${ }^{, 387}$ Professor Rollin M. Perkins propounded such an argument when he asserted that "California could not validly make it a crime for its citizens to 'play the slot machines' in Las Vegas, Nevada, where this is lawful. Such a statute would violate the full faith and credit clause. ${ }^{, 388} \mathrm{He}$ is not alone in this view. ${ }^{389}$

This analysis is incorrect, however, because it conflates two aspects of choice of law: (1) determining whether two (or more) states have legislative jurisdiction; and, if they do, (2) determining which state's law applies in a particular litigation. ${ }^{390}$ As of the time Perkins was writing, full faith and

386 A full exposition must await another day. Rosen, supra note 9, at 8-40.

387 U.S. CONST. art. IV, § 1.

388 Rollin Perkins, The Territorial Principle in Criminal Law, 22 HASTINGS L.J. 1155, 1164 (1971). It should be noted that Perkins' analysis does not run afoul of the principle that full faith and credit does not apply to criminal laws insofar as that principle simply means one state is not required to apply the penal statutes of another. See, e.g., Nelson v. George, 399 U.S. 224, 229 (1970) ("[T]he Full Faith and Credit Clause does not require that sister States enforce a foreign penal judgment."). Perkins is arguing the wholly different proposition that the Home State does not have the power to regulate in the first instance.

389 See PERKINS \& BOYCE, supra note 25, at 42 (concluding that full faith and credit would preclude such a regulation); Larry Kramer, Note, Jurisdiction over Interstate Felony Murder, 50 U. CHI. L. REV. 1431, 1451 n.111 (1983) ("The availability to the states of a nationality principle to justify punishing citizens for acts committed in other states may be limited by the full faith and credit clause of the Constitution .....').

390 Cf. Kramer, supra note 125, at 280 (making clear the two-step nature of choice-oflaw problems); Roosevelt, supra note 218, at 2467-68 (distinguishing between "rules of 
credit, unlike due process, did not govern the scope of a state's legislative jurisdiction. Instead, full faith and credit determined which state's law was to be applied by a particular court in the course of a given litigation. Thus, the Court explicitly observed in several of its seminal Full Faith and Credit Clause cases that, although the clause permitted the forum state to apply its law to the controversy, the nonforum state would have been free to apply its laws to the self-same parties and occurrences had the lawsuit been filed there $;{ }^{391}$ this of course presumes that both states had regulatory powers over the parties and occurrence, and that the only question under full faith and credit was which state's laws were to be applied by the particular court that was hearing the matter. ${ }^{392}$ Consider as well the case of Thomas $v$.

scope" and "conflict rules").

391 See, e.g., Pac. Employers Ins. Co. v. Indus. Accident Comm'n, 306 U.S. 493, 502 (1939) ("[T]he full faith and credit clause does not require one state to substitute for its own statute, applicable to persons and events within it, the conflicting statute of another state, even though that statute is of controlling force in the courts of the state of its enactment with respect to the same persons and events." (emphasis added)); Ala. Packers Ass'n v. Indus. Accident Comm'n, 294 U.S. 532, 540 (1935) (concluding that California law could apply by virtue of the Full Faith and Credit Clause even though "the employee, had he chosen to do so, could have claimed the benefits of the Alaska statute" by suing in Alaska).

392 In the few cases where the Court held that full faith and credit required the forum to apply nonforum law, the rationale was not that full faith and credit limited the forum's legislative jurisdiction. Rather, under the Court's analysis, only one state's law (the nonforum's) was conceivably applicable and full faith and credit disallowed the forum state from refusing to apply that law. See John Hancock Mut. Life Insur. Co. v. Yates, 299 U.S. 178 (1936) (requiring the forum state to apply a nonforum state's contract law to an insurance policy bought in the nonforum state by an insured who spent the remainder of his life in the nonforum state); Bradford Elec. Light Co. v. Clapper, 286 U.S. 145 (1932) (applying the nonforum state's worker compensation laws to resolve claims arising from the employee's death while working in the forum state, in which he neither resided nor regularly worked). These opinions reveal that the Court's conclusion that the forum was without legislative jurisdiction did not rest on the Full Faith and Credit Clause, but derived from the Court's territory-based conception of state sovereignty, under which a state's legislative jurisdiction was deemed to be coterminous with its physical borders. See, e.g., Pennoyer v. Neff, 95 U.S. 714,722 (1877) ("And so it is laid down by jurists, as an elementary principle, that the laws of one State have no operation outside its territory ...."). That is why the opinions in Clapper and Yates localize the regulated entities in the nonforum state, see Clapper, 286 U.S. at 158 ("The relation between Leon Clapper and the company was created by the law of [the nonforum]; and as long as that relation persisted its incidents were properly subject to regulation there."); Yates, 299 U.S. at 182 ("[T]he contract of insurance was made, and the death of the insured occurred in [the nonforum state]. In respect to the accrual of the right asserted under the contract, or liability denied, there was no occurrence, nothing done, to which the law of [the forum] could apply." (citation omitted)), and undertake to explain why the application of nonforum law is not extraterritorial, see Clapper, 286 U.S. at 158 ("The mere recognition by the courts of one state that parties by their conduct have subjected themselves to certain obligations arising under the law of another State is not to be deemed an extraterritorial application of the law of the State creating the obligation."); Yates, 299 U.S. at 182 ("Such recognition does not give to the [nonforum state's] statute extraterritorial effect."). Even under this territory-based system, there were discrete doctrines that gave states 
Washington Gas Light Co., where the Court ruled that full faith and credit required that the District of Columbia be allowed to apply its workmen's compensation laws to one of its residents who had sustained a work-related injury in Virginia - even though Virginia already had applied its laws in respect of the identical person and occurrence. ${ }^{393}$ Thomas thus definitively establishes that full faith and credit doctrine coexisted with concurrent regulatory jurisdiction, for it upheld the application of both states' laws to the identical occurrence. Thus, to return to Professor Perkins' example, full faith and credit at the time of Perkins' article said nothing about whether California had the power to regulate its citizens when they were in Nevada; full faith and credit only had something to say about which state's laws would be applied in a litigation in Nevada.

To be sure, since Professor Perkins' article was published, the Supreme Court has held that full faith and credit does limit legislative jurisdiction. The Court has, however, held that full faith and credit and due process requirements impose precisely the same choice-of-law limitations. ${ }^{394}$ In other words, the Court has folded full faith and credit into the due process inquiry that this Article explored at length above. ${ }^{395}$ As shown above, under today's combined due process/full faith and credit analysis, California could regulate its citizens' conduct in Nevada because such conduct affects California's legitimate paternalistic policy and interests in guarding the

legislative powers vis-à-vis acts undertaken outside their physical borders. See, for examples, Strassheim v. Daily, 221 U.S. 280, 285 (1911), discussed supra notes 34-36 and accompanying text; and Clapper, 286 U.S. at 156. In Clapper the Court states: "But, obviously, the power of [the nonforum state] to effect legal consequences by legislation is not limited strictly to occurrences within its boundaries." Id. (emphasis added). Over time, the Court's territorialist conception of sovereignty has been modified. No longer talismanic, territorial location now is one among many factors deemed relevant in determining whether a state has a significant contact such that application of its law is neither arbitrary nor fundamentally unfair. See Phillips Petroleum Co. v. Shutts, 472 U.S. 797, 819 (1985) (acknowledging the visibility of a forum state's "own interests in furthering its public policy" when deciding whether to apply the laws of nonforum states). The bottom line is that as of the time of Professor Perkins' article, the Full Faith and Credit Clause was not used to determine the scope of a state's legislative jrisdiction but instead was a provision that disallowed the forum from refusing to apply nonforum law where oly nonforum law conceivably was applicable.

393448 U.S. 261, 284-85 (1980).

394 See Sun Oil Co. v. Wortman, 486 U.S. 717, 735 n.2 (1988) (stating that full faith and credit imposes no additional constitutional limitations beyond due process in the choice of law context); WEINTRAUB, supra note 32, at 624-25 ("[T]he full faith and credit clause imposes no further limitation on a state's choice of law than is imposed by the basic requirements of due process.").

${ }^{395}$ See Shutts, 472 U.S. at 818 (holding that a state can apply its law, consistent with the requirements of due process and full faith and credit, only if there are "significant contact[s] ... creating state interests, such that choice of law is neither arbitrary nor fundamentally unfair"). See generally supra Part I.C (discussing what this case requires). 
welfare of third parties (such as the gambler's family). Such conduct accordingly qualifies as significant contacts that create state interests, such that the application of California law would be neither arbitrary nor fundamentally unfair. ${ }^{396}$ In short, the conclusion is the same irrespective of the time frame consulted: under no circumstances would full faith and credit bar California from regulating its citizens' gambling activities in Nevada. If Nevada also wished to regulate the Californian when she is in Nevada, we accordingly would be presented with a circumstance of concurrent jurisdiction.

There is another important point to note about our country's regime of concurrent regulatory jurisdiction. Each state's regulations may materially conflict. It is the conflict between their laws, after all, that typically provides the incentive for litigating parties to engage in choice-of-law battles; one state's law is more favorable to one of the parties. ${ }^{397}$ Our law of full faith and credit thus contemplates a regime of concurrent regulatory jurisdiction under which the parties' legal rights may vary depending on which state's law is deemed to apply. In short, regulatory authority is concurrent even when the states' regulations substantively conflict.

There is concurrent jurisdiction in respect of certain criminal matters, as well. Consider the Model Penal Code. The Code provides that a Home State has legislative jurisdiction if "either the conduct that is an element of the offense or the result that is such an element occurs within" the Home State. ${ }^{398}$ Many states have adopted these provisions, ${ }^{399}$ and as long ago as 1966, one commentator observed that courts have found no difficulty in finding an act or result occurring in their state even where the conduct "for all important purposes took place beyond the state's boundaries. ${ }^{400}$ For example, the Court of Appeals of Alaska upheld the prosecution of a divorced father for custodial interference under an Alaskan statute despite the fact that "all the acts constituting the offense were committed outside of

396 Supra Part I.C.

397 See, e.g., Pac. Employers Ins. Co. v. Indus. Accident Comm'n, 306 U.S. 493, 498-99 (1939) (considering whether Massachusetts law, under which an employee was deemed to have waived his common law right of action to recover for personal injuries suffered during the course of employment unless he has given appropriate notice to his employer in writing, or California law, which did not have such a notice requirement, applied).

398 MODEL PENAL CODE $§ 1.03(1)$ (a) (1985).

399 E.g., ARIZ. REV. STAT. ANN. § 13-108(A)(2) (West 2001) (conferring jurisdiction over out-of-state conspiracies to commit a crime in Arizona if the offenders have also done something within the state to further that conspiracy); 18 PA. CONS. STAT. ANN. § 102(a)(2) (West 1998) (giving Pennsylvania jurisdiction if events occurring outside the state constitute, under Pennsylvania law, a conspiracy to commit a crime in Pennsylvania).

400 B.J. George, Jr., Extraterritorial Application of Penal Legislation, 64 MICH. L. REV. 609, 622 (1966). 
the state;" $" 401$ the child had traveled to Arizona to spend the summer with her father, in accordance with the divorce decree's visitation schedule, but the father prevented the child from returning to her mother in Alaska at summer's end. ${ }^{402}$ This is an example of concurrent jurisdiction because the father's actions were also governed by Arizona law. ${ }^{403}$

Further, there is concurrent regulatory jurisdiction in criminal matters even where there is a policy conflict between the Home and Host States. Consider once again the Model Penal Code. ${ }^{404}$ One section states that the Home State can exercise legislative jurisdiction if the "actor purposely or knowingly caused the result within the [Home] State," even though "causing a particular result is an element of an offense and the result is caused by conduct occurring outside the State that would not constitute an offense if the result had occurred there. ${ }^{, 405}$ Another provision addresses the converse situation. It states that as long as a "legislative purpose plainly appears to declare the conduct criminal regardless of the place of the result," the Home State may treat an act committed in the Home State as criminal even if "causing a specified result or a purpose to cause or danger of causing such a result is an element of an offense and the result occurs or is designed or likely to occur only in another jurisdiction where the conduct charged would not constitute an offense., ${ }^{, 406}$

Finally, it is important to note that there is more extensive concurrent regulatory jurisdiction in criminal than civil matters in one important respect. A civil judgment rendered in a Host State's courts must be granted full faith and credit by a Home State's courts and accordingly will have res judicata effects, barring application of the Home State's laws if the parties or their privies were to file a subsequent lawsuit in the Home State in

401 Wheat v. Alaska, 734 P.2d 1007, 1007 (Alaska Ct. App. 1987).

402 Id. at 1007-08.

403 In Arizona, the law is as follows:

A. A person commits custodial interference if, knowing or having reason to know that the person has no legal right to do so, the person does one of the following:

..

3. If the person is one of two persons who have joint legal custody of a child takes, entices or withholds from physical custody the child from the other custodian.

4. At the expiration of access rights outside this state, intentionally fails or refuses to return or impedes the return of a child to the lawful custodian.

ARIZ. RE V. STAT. ANN. § 13-1302(A) (West 2001).

404 Additional evidence can be found under double jeopardy jurisprudence. See infra Part III.B (discussing the implications of concurrent regulatory jurisdiction when the state laws involved materially differ from one another).

405 MODEL PENAL CODE $§ 1.03(3)$ (1985).

406 Id. $\S 1.03(2)$. 
relation to the same transaction or occurrence. ${ }^{407}$ In this sense, it could be said that concurrent legislative jurisdiction in the civil context largely ends at the moment a court renders a civil judgment. ${ }^{408}$ This is not so, however, in the context of criminal law. Full faith and credit is not applicable to criminal judgments, ${ }^{409}$ and the Double Jeopardy Clause permits the Home State to prosecute on the basis of a transaction or occurrence that already has been the subject of the Host State's prosecution. ${ }^{410}$

Tellingly, the Court has justified this outcome under the Double Jeopardy Clause on the basis that concurrent jurisdiction is a natural and acceptable byproduct of a federal system of meaningfully empowered states. The key case on this issue is Heath v. Alabama. ${ }^{411}$ The defendant there had been convicted in Georgia for "malice murder" and was subsequently prosecuted in Alabama for "murder during a kidnapping." 412 The Supreme Court ruled that the two crimes were greater and lesser offenses and hence the "same" offense for purposes of Double Jeopardy if applied within a single state. ${ }^{413}$ The Court nonetheless upheld the two convictions, ruling that the Double Jeopardy Clause does mot bar successive prosecutions by two states for the same conduct. ${ }^{414}$

Heath's holding turned on the fact that a single act may implicate the regulatory interests of two states, and the Court held that under the "dual sovereignty doctrine," each sovereign state is entitled to vindicate its own interests: "The dual sovereignty doctrine is founded on the common-law conception of crime as an offense against the sovereignty of the government. When a defendant in a single act violates the 'peace and dignity' of two sovereigns by breaking the laws of each, he has committed

\footnotetext{
407 See Baker v. Gen. Motors Corp., 522 U.S. 222, 233 (1998) ("For claims and issue preclusion (res judicata) purposes .... [t]he judgment of the rendering State gains nationwide force.".).

408 There are two important caveats here. First, this might have no effect on the prelitigation regulatory effect of the laws because parties would not know in which forum a lawsuit first would be filed and so would have the incentive to abide by both states' laws. Second, very frequently only one state has regulated the relevant field, and so only it is likely to be the forum; under a circumstance where the Home State has regulated and the Host State has not, the only way there first could be a judgment in the Host State would be by means of declaratory judgment.

409 See, e.g., Nelson v. George, 399 U.S. 224, 229 (1970) (noting that states do not have to enforce other states' penal judgments); $c f$. The Antelope, 23 U.S. 66 (10 Wheat), 122-23 (1825) ("The courts of no country execute the penal laws of another.").

410 See Heath v. Alabama, 474 U.S. 82, 88 (1985) (holding that "successive prosecutions by two States for the same conduct are not barred by the Double Jeopardy Clause").

411474 U.S. 82 (1985).

412 Id. at $84-85$.

413 Id. at 87.

${ }^{414} I d$. at $88-89$.
} 
two distinct 'offences.", "415 “[T] he crucial determination" for purposes of the dual sovereignty doctrine, said the Court, "is whether the two entities that seek successively to prosecute a defendant for the same course of conduct can be termed separate sovereigns. This determination turns on whether the two entities draw their authority to punish the offender from distinct sources of power. ${ }^{416}$ The Court then held that states qualify as "separate sovereigns." Their "powers to undertake criminal prosecutions derive from separate and independent sources of power and authority originally belonging to them before admission to the Union and preserved to them by the Tenth Amendment.",117

One might suggest that Heath's acceptance of concurrent jurisdiction is limited to circumstances where there is no conflict between state policies; after all, both Alabama and Georgia proscribed the defendant's behavior. ${ }^{418}$ This, however, would be a dubious limitation, for the rationale deployed by the Heath Court in no way turns on the absence of conflict. Instead, the opinion focuses on the fact that a single act can implicate the legitimate interests of two states, and it is not infrequently the case that different jurisdictions treat identical acts differently.

Additional powerful support for the conclusion that Heath's holding does not depend on the absence of conflict between the relevant jurisdictions is in the Heath Court's treatment of Nielsen v. Oregon, ${ }^{419}$ a concurrent jurisdiction case whose holding pointed in an opposite direction than that taken by the Court in Heath. Heath accordingly had to distinguish Nielsen. Importantly, even though Nielsen involved conflict between two states, the Heath Court's analysis did not draw a distinction on the basis of that conflict. Nielsen concerned a circumstance in which Congress granted Oregon and Washington concurrent jurisdiction over the Columbia River.

415 Id. at 88 (quoting United States v. Lanza, 260 U.S. 377, 382 (1992)).

416 Id.

417 Id.

418 For such a suggestion, see Kreimer, Law of Choice, supra note 5, at 481, stating: "[T]here is a difference between seeking to deter acts that both states agree are evil and seeking to punish an action ... protected by ... the state in which it occurs." On a separate point, one might think that the Double Jeopardy Clause is implicated only when two states prohibit a particular activity and then prosecute, and that Double Jeopardy is not even of threshold relevance unless there is no conflict between the two sovereigns. But this is not so. Consider the Heath case: Imagine that the defendant had been acquitted in Georgia for malice murder because his actions did not satisfy the statutory elements but that the defendant's actions would have constituted murder during kidnapping under Alabama law. In such a case there is "conflict" between the two states' laws, yet one would expect that the defendant would invoke the Double Jeopardy Clause to preclude prosecution in Alabama were it not for the dual sovereignty doctrine.

419212 U.S. 315 (1909). 
The Court in Nielsen set aside the conviction of a Washington resident in an Oregon court for operating a particular type of fishing net pursuant to a valid Icense from Washington. The Nielsen Court's rationale had been explicitly tied to the presence of an interstate conflict of policies: where "the opinion of the legislatures of the two States is different ... the one State cannot enforce its opinion against that of the other, at least as to an act done within the limits of that other State. ${ }^{, 420}$

This would have been a simple basis on which the Heath Court could have distinguished Nielsen. But this Heath did not do. Instead, it held that "Nielsen is limited to its unusual facts and has continuing relevance, if at all, only to questions of jurisdiction between two entities deriving their concurrent jurisdiction from a single source of authority [i.e., Congress]. ${ }^{, 421}$ In short, Heath did not limit Nielsen on the basis of interstate conflict, which had figured prominently in the Nielsen opinion itself, but instead distinguished the case on the ground that the concurrent jurisdiction had not emerged from inherent powers of the two states but instead had been granted by the Congress. The approach taken toward Nielsen in Heath accordingly supports strongly the view that Heath's rationale extends to circumstances of policy conflict between or among states as long as the two or more jurisdictions' powers are derived from independent sources. And, as Heath itself makes clear, state criminal law satisfies this condition: "The Constitution leaves in the possession of each State 'certain exclusive and very important portions of sovereign power.' Foremost among the prerogatives of sovereignty is the power to create and enforce a criminal code. ${ }^{, 422}$ This suggests that a Home State's criminal jurisdiction emerging from the police power is concurrent with the Host State's criminal jurisdiction over a visitor from the Home State, even where there is substantive conflict between the two states' criminal laws.

Understanding the constitutional law governing concurrent jurisdiction helps to shed Ight on an intriguing hypothetical mentioned above ${ }^{423}$ that was originally put forward by Professor Kreimer. Suppose that New Jersey recognizes a "battered wife" defense, that Pennsylv ania does not, and that a Pennsylvanian battered wife kills her Pennsylvanian husband while both are

420 Id. at 321 .

421 Heath, 474 U.S. at 91

422 Id. at 93 (quoting THE FEDERALIST No. 9, at 55 (Alexander Hamilton) (J.E. Cooke ed., 1961)); see also id. at 93 ("States, 'as political communities, [are] distinct and sovereign, and consequently foreign to each other.", (quoting Bank of United States v. Daniel, 37 U.S. (12 Pet.) 32, 54 (1838))); id. (suggesting that "States are no less sovereign with respect to each other than they are with respect to the federal government").

423 Supra note 5 and accompanying text. 
on vacation in New Jersey. Professor Kreimer argues that New Jersey could not deny the noncitizen wife a battered wife defense in a New Jersey prosecution. ${ }^{424}$ That would ppear to be correct insofar as full faith and credit does not require one state (here, New Jersey) to apply the penal laws of another (here, Pennsylvania's rejection of the battered wife defense). ${ }^{425}$ This is of only limited practical import, however, because the Double Jeopardy Clause would not preclude the Pennsylvanian wife from accomplishing what her home jurisdiction does not want to permit. Pennsylvania also could prosecute the wife, its own citizen, and apply its law of homicide, which does not recognize the defense. ${ }^{426}$ Once again, the two states have concurrent, conflicting regulatory jurisdiction under current law.

To quickly conclude, concurrent legislative jurisdiction among states is an entrenched part of federal constitutional law. It permits all interested states to regulate so as to protect their interests. Moreover, states' criminal jurisdiction is in one important respect more extensive than their civil legislative jurisdiction: whereas full faith and credit's constitutional rules of res judicata preclude a second trial where there has been a civil judgment in another state, neither the Full Faith and Credit nor the Double Jeopardy

424 See Kreimer, Law of Choice, supra note 5, at 499 n.169 ("It would plainly violate the privileges and immunities clause to make [the battered woman] defense only available [to New Jersey citizens].”).

${ }^{425}$ The Antelope, 23 U.S. (10 Wheat) 66, 123 (1825). Professor Kreimer analyzes the question under the Privileges and Immunities Clause, but for reasons discussed above I do not believe that Clause to be applicable to the issue at hand: the defense would not appear to fall under a protected privilege or immunity and, in any event, New Jersey could justify application of Pennsylvania's law on the basis of not wanting to interfere with Pennsylvania law. Supra Parts II.A.1-.3.

${ }^{426}$ Pennsylvania has enacted the Model Penal Code provision that permits a Home State to prosecute for acts performed out of state that were legal in the Host State but prohibited by the Home State. See 18 PA. Cons. Stat. ANN. § 102(a)(6) (West 1998) (prohibiting extraterritorial conduct that violates a Pennsylvania statute where the statute is express and reasonably related to the Commonwealth's interest). If the Sixth Amendment's vicinage requirement were incorporated against the states-as of now, "the Supreme Court has never directly addressed the issue," Kreimer, Law of Choice, supra note 5, at 484-85-then Pennsylvania would be permitted to prosecute its citizen only if at least some of the conduct constituting the offense occurred in the Home State. See United States v. Rodriguez-Moreno, 526 U.S. 275, 278-79 (1999) (describing the federal constitutional vicinage requirement in criminal cases). Were the vicinage requirement applied to the states, states wanting the power to prosecute particular crimes for extraterritorial activities would be well advised to draft those criminal statutes in a manner that expressly constituted as elements of the offense aspects of the activity likely to be performed in the Home State or the activities' effects. 
Clause preclude the second state from prosecuting, even after there has been a criminal determination in the first state.

\section{B. Concurrent Jurisdiction and Interstate Conflict-A Prologue}

One consequence of concurrent legislative jurisdiction is that more than one state's laws may apply to a particular activity. This can present a difficulty if the two (or more) states' laws materially differ from one another. In fact, it was this very possibility of interstate conflict that led Professor Brilmayer to argue against the existence of concurrent legislative jurisdiction vis-à-vis issues on which states are deeply divided; by eliminating one state's legislative jurisdiction (the Home State's), Professor Brilmayer sought to eliminate the very possibility of interstate conflict. ${ }^{427}$ As explained above, however, there is no constitutional principle that so readily eliminates difficult conflicts. Moreover, the absence of a simple rule like "the Home State trumps" is a good thing, for simplicity's costs in these circumstances would be too grave in respect of the interests of the Home State and the federal system more generally. ${ }^{428}$ Of course, a full exposition of how our system of concurrent jurisdiction manages interstate conflict is beyond the scope of this Article; it is a core part of the field of conflict of laws, ${ }^{429}$ about which I shall not say much here. In what remains, I hope only to sketch the contours of the problems of interstate conflict that arise from Home State extraterritorial regulation, as well as to identify the several approaches to accommodating such conflicts that are already present in the caselaw. Although a fuller exposition must await another day, this discussion will provide the basic concepts necessary for understanding how a system of concurrent, conflicting jurisdiction can be workable.

\section{A Simple Taxonomy of Conflicts}

Before discussing how our federal system handles interstate conflict, it is necessary to understand the metes and bounds of the problem. To begin, it is important to recognize that the exercise of Home State extraterritorial powers does not always give rise to conflicts with the Host State. Consider

427 See supra Part II.D.1 (noting Professor Brilmayer's view that “territoriality trumps residence").

428 See supra Part II.D (noting that an univariable dictate like "Home State trumps" could undermine sovereign equality and the Host State's ability to pursue paternalistic and norm-shaping ends).

429 See, e.g., DAVID P. CURRIE ET AL., CONFLICT OF LAWS, at v (6th ed. 2001) ("The power of different [governmental] bodies to make or administer law is often unclear and, even when clear, frequently overlaps. Conflicts arise, and a way is needed to resolve them. This, broadly speaking, is the subject matter of "conflict of laws."”). 
the circumstance where only the Home State has regulated the activity in question and the absence of Host State regulation signifies the absence of Host State regulatory interest in the matter. (To be sure, the absence of regulation does not always mean an absence of interest-as is discussed immediately below - but it sometimes may). For example, think about Wisconsin's milk regulations in the Dean Foods case. ${ }^{430}$ Whereas Wisconsin felt strongly about discouraging the payment of premiums to large Wisconsin dairy farms, it is likely that Illinois was indifferent to the matter. ${ }^{431}$ Under these circumstances, concurrent jurisdiction permits the interested state to ensure that its laws are followed, irrespective of where its citizen happens to be located. The Host State should not care much, if at all, and the Home State that wishes to regulate its citizens extraterritorially will be quite content. Under this situation, which might be called a "No Conflict" circumstance, ${ }^{432}$ concurrent jurisdiction presents no difficulties in respect of interstate conflict; the Home State's law can be unproblematically applied to its peripatetic citizens. A Home State with a motorcycle helmet law that sought to apply its regulation to one of its citizens while she was in a Host State that had no such laws might be another No Conflict circumstance. ${ }^{433}$

Frequently, however, there is a direct conflict between the policies of the Host and Home States. Two dimensions of the conflict are particularly important to note for present purposes. The first is the relative importance of each state's policy. Of course, it is frequently very difficult in practice to make such a comparison: there are uncertainties as to what the policy

430 Supra Part II.C.2.

431 To be sure, it is impossible to know for certain the legislative intent lurking behind the Wisconsin statute, which on its face was silent as to extraterritoriality, and much less the intent behind the absence of regulation in Illinois. Professor Brilmayer has put forward a powerful critique of the concept of "governmental interests" in the conflict-of-laws context, arguing that it amounts to little more than a fictitious constructive intent. See Lea Brilmayer, Interest Analysis and the Myth of Legislative Intent, 78 MICH. L. REV. 392, $402-07$ (1980). Brilmayer's argument ultimately is "not an objection to a choice of law method alone" but "is an objection to a conventional method of statutory con struction." Kramer, supra note 125, at 300. "The objection thus really amounts to a claim that courts are unable to do something that they do all the time." Id. at 300-01. For this reason, I assume for present purposes that courts are capable of assessing legislative intent, even if it only amounts to "imaginative reconstruction," "for that is a deep part of contemporary legal practice. Id. at 300 (quoting RICHARD A. POSNER, THE FEDERAL COURTS: CRISIS AND REFORM 287 (1985)).

432 This is analogous to "false conflicts" under the conflict-of-laws approach known as interest analysis. LEA BRILMAYER, CONFLICT OF LAWS 51 (2d ed. 1995).

433 It is possible, however, that behind the absence of a mandatory helmet law is a state policy of supporting personal choice in respect of wearing helmets, in which case there would be a conflict between the Home and Host State policies. 
behind a particular law is in the first place, ${ }^{434}$ and there are often incommensurability problems when "weighing" one state's interest against another's. ${ }^{435}$ Nevertheless, it is surely possible that one state's interest in a given matter may uncontroversially outweigh another state's interest. For example, it long has been the case under the law of full faith and credit that the Home State's interest in its citizens on the issues of marriage and divorce has been held to exceed the Host State's. ${ }^{436}$ Let us call this the "Relative Interests Dimension" of interstate conflict.

The second dimension concerns whether and to what extent the two (or more) states' rules give rise to inconsistent demands over a particular person or transaction. Let this be known as the "Compatibility Dimension" of interstate conflict. Most problematically, a visitor could be subject to the laws of two states that require mutually inconsistent behaviors such that both cannot be complied with simultaneously. Consider, for example, a "safe" State $A$ that set fifty-five miles per hour as the maximum traveling speed on its highways and that sought to impose that limit on its citizens' out-of-state highway travels, and consider further what would happen if one of its citizens visited a neighboring "macho" State $B$ that set sixty-five miles per hour as the highway minimum. I will call this a "Hard Conflict" circumstance in respect of the Compatibility Dimension.

Most often, however, it is possible for a person to abide by both states' rules, even if they are at odds with one another. Consider antigambling State $A$ that wished to prevent its citizens from gambling out of state and a pro-gambling state, such as Nevada. A citizen of State $A$ can comply with both states' laws by not gambling - after all, Nevada law does not mandate that its visitors gamble. Nevertheless, there typically is a conflict between the two states' laws along the Relative Interests dimension of conflicts; Nevada, for example, wants people to gamble in Nevada. Another example is the relationship between New Jersey and Pennsylvania law concerning the battered wife defense: though New Jersey recognizes the defense,

434 See supra note 431 (illustrating the difficulty in determining legislative intent).

435 See generally Matthew Adler, Law and Incommensurability: Introduction, $146 \mathrm{U}$. PA. L. REV. 1169, 1170 (1998) (noting that "'incommensurability' means the absence of a scale or metric" and that this might be understood as referring to a situation where "no numerical ranking of the options in the order of their comparative worth is possible").

436 See Williams v. North Carolina, 325 U.S. 226, 229-30 (1945) (ruling that only the place of "permanence" should have the power to alter "legal relations and responsibilities" of such "utmost significance" as marriage). Similarly, in Sosna v. Iowa, 419 U.S. 393, 396 (1975), the Court upheld against challenges grounded in equal protection and the right to travel an Iowa statute that imposed a one-year residency requirement for divorce on the ground that Iowa may reasonably be justified in, inter alia, not wanting to "become a divorce mill for unhappy spouses" who likely will return to their Home States soon afterward. Id. at 407. 
merely having this law in place does not, of course, dictate that battered wives kill their husbands-that is, a battered Pennsylvanian visiting New Jersey abides by both states' laws by not taking the life of her abusive spouse. On the other hand, New Jersey may well not want any battered spouse, whether hailing from New Jersey or elsewhere, to go to jail for killing her batterer in New Jersey. I will call these cases of "Soft Conflict" ${ }^{437}$ along the Compatibility Dimension.

As will be discussed below, Hard Conflicts are particularly problematic. They only infrequently occur, however. None of the examples of extraterritorial regulation discussed in this Article, for example, would create Hard Conflicts. Hard Conflicts are rare because the Host State's law typically is permissive rather than mandatory. For example, pro-gambling states do not require that visitors gamble, and states without parental notification laws do not require that pregnant minors undergo abortions without parental consent. For this reason, Home State extraterritoriality ordinarily results in situations of No Conflict or Soft Conflict, not Hard Conflict.

\section{Why Interstate Conflicts Are Not "Unworkable"}

There are three plausible strategies for coping with potential interstate conflict. First, the conflict can be eliminated by determining that only one state in fact has legislative jurisdiction; Professor Brilmayer, as discussed above, ${ }^{438}$ takes this approach. While her principle of "Host State trumps" is problematically coarse, there is merit to her general method. As I will show below, there are several constitutional provisions that dispel conflicts by identifying only one state as having legislative jurisdiction, though they do not eliminate as many conflicts as Professor Brilmayer's principle does. Second, a nonconstitutional conflict-of-laws regime could be deployed under which one state's law is identified as applicable in the circumstance at hand. Third, both states' laws could be deemed to be applicable, and the individual then could be held responsible to conform her behavior to both regimes. Each of these approaches is applicable in certain circumstances. By appropriately utilizing these three approaches, the interstate conflict that naturally arises under a regime of concurrent jurisdiction can be

437 Professor Brilmayer makes a similar distinction. See Brilmayer, supra note 26, at 874-75 ("Most states that choose not to prohibit abortion to the extent constitutionally permissible are not merely expressing a simple lack of interest in the abortion issue. They are, instead, affirmatively granting to those within their borders the freedom to make the choice ....").

${ }^{438}$ Supra Part II.D.1. 
successfully managed. ${ }^{439}$

\section{a. Eliminating conflict by identifying a single source of law}

Four federal constitutional principles eliminate a significant number of potential conflicts by determining that only one state has legislative jurisdiction over particular persons or transactions. Due process is the first: it precludes states without reasonable connections to the matter at hand from regulating. ${ }^{440}$ The second is the Dormant Commerce Clause's inconsistent regulations test. As discussed above, this does not impose a general ban on inconsistent regulations, but instead forecloses those inconsistencies that unduly interfere with the national economy. ${ }^{41}$ This is an important, albeit limited, constraint on state legislative power. The third limitation emerges from the right to travel. Professor Kreimer has suggested that the right to travel serves a role analogous to Professor Brilmayer's "Host State trumps" principle: The Kreimerian right to travel effectively eliminates Home State legislative jurisdiction over its traveling citizens by creating a right on behalf of the traveler to be governed by the Host State's laws. ${ }^{442}$ While neither precedent nor policy considerations support such a view of the right to travel, ${ }^{443}$ the right to travel likely eliminates the Home State regulatory jurisdiction that creates Hard Conflicts. Hard Conflicts, it could be said, run afoul of the right to travel by interfering with a citizen's right to leave her Home State for the purpose of visiting another state. This is so insofar as the specter of inevitably breaking one state's laws might well be such a disincentive to interstate travel that it affirmatively interferes with the right to travel, which is part and parcel of American federalism. ${ }^{444}$

The fourth constitutional provision that properly plays a role in sorting out interstate conflicts is the Full Faith and Credit Clause. I mention it last only because the role it appropriately plays likely would require a reworking

439 As stated above, I intend here to provide only a cursory overview of these methodologies. A fuller exposition of their appropriate scope must await another day.

440 See, e.g., Phillips Petroleum Co. v. Shutts, 472 U.S. 797, 819-20 (1985) (holding that the forum state of Kansas could not apply its law because Kansas vas only "casually or slightly related to the litigation").

441 It is quite possible that the Dormant Commerce Clause on its own would bar State $A$ from extraterritorially regulating in respect of highway speed; the Court in CTS Corp. v. Dynamics Corp. of America, 481 U.S. 69 (1987), conceptualized cases striking down states' efforts to set maximum train and truck lengths as having been decided under the risk-ofinconsistent-regulations principle. Supra Part II.C.1.d.

442 Supra Part II.B.

443 Id.

444 See Saenz v. Roe, 526 U.S. 489, 500 (1999) (holding that the right to travel includes "the right of a citizen of one State to enter and to leave another State"). 
of contemporary full faith and credit doctrine; that is, the analysis that follows is normative and prescriptive, rather than positive in nature.

The Full Faith and Credit Clause is both textually and conceptually suited to playing a role in sorting out interstate conflicts. By its terms, the clause determines when "[f]ull faith and credit shall be given in" one state to the statute ${ }^{445}$ of another state; it thus addresses directly the issue presented by interstate conflict of determining which state's law is applicable. The Full Faith and Credit Clause is conceptually suited to this task because, unlike the Dormant Commerce Clause and the right to travel, its scope of inquiry naturally includes an assessment of whether the Home State or the Host State has overreached. The Dormant Commerce Clause's risk-of-inconsistent-regulations test, developed to explain under what circumstances extraterritoriality is problematic, ${ }^{446}$ most naturally would be construed as limiting only the Home State. The same likely applies to the right to travel: it too is most readily construed as a limit on only the Home State, for it is the Home State's regulation that is most naturally viewed as the obstacle to its citizens' ability to travel.

As constitutional limits on interstate conflict in circumstances where due process does not eliminate one state's legislative jurisdiction, the Dormant Commerce Clause and the right to travel are ncomplete because they erect virtually irrebuttable presumptions that the state that has overreached is the Home State. This is problematic because it surely is plausible that the Host State has sought to inappropriately interfere with the visitor's relationship to her Home State and, accordingly, that it is the Host State that has precipitated the problematic interstate conflict. The Full Faith and Credit Clause, in contrast to the right to travel and the Dormant Commerce Clause, invites an inquiry as to whether the Home or Host State appropriately has the regulatory power. In fact, an old line of full faith and credit decisions employed this very analytic, balancing the Host and Home State's interests in applying their laws and holding in various circumstances that the forum/Host State had to apply the Home State's law. ${ }^{447}$ In short,

\footnotetext{
445 The term "public acts" that is found in the Full Faith and Credit Clause has been construed to mean statutes and common law. See Baker v. Gen. Motors Corp., 522 U.S. 222, 232 (1998) ("Our precedent differentiates the credit owed to laws (legislative measures and common law) and to judgments.").

446 See supra note 309 (discussing CTS Corp. v. Dynamics Corp. of America, 481 U.S. 69 (1987), and the inconsistent-regulations standard for judging extraterritoriality).

447 See, e.g., Order of United Commercial Travelers of Am. v. Wolfe, 331 U.S. 586, 624 25 (1947) (holding that a South Dakota court must give effect to an Ohio Law). This case's holding was later limited by the Supreme Court's opinion in Clay v. Sun Insurance Office, Ltd., 377 U.S. 179, 183 (1964), which characterized Wolfe as "a highly specialized decision dealing with unique facts.” See also Bradford Elec. Light Co. v. Clapper, 286 U.S. 145, 163
} 
under this caselaw, full faith and credit took into xcount the Relative Interests Dimension of interstate conflict and determined when the Home State's interests overrode the Host State's interests such that the Home State's law trumped the Host State's - even in the Host State's courts. ${ }^{448}$ To be sure, most courts and commentators believe this approach to full faith and credit to be long dead. ${ }^{449}$ Though I believe this to be an overstatement, ${ }^{450}$ it is true that today's doctrine of full faith and credit would have to be reworked were the clause to play the role described here. ${ }^{451}$ In a future work, I hope to explain why and how contemporary full faith and credit doctrine should be modified. ${ }^{452}$

\section{b. Eliminating conflict by recourse to ordinary conflict-of-laws principles}

Many, perhaps most, interstate conflicts will not be resolved by means of the above-mentioned constitutional principles. The next set of tools for resolving such conflicts is ordinary conflict-of-laws doctrine. Like the constitutional principles, this approach operates by effectively eliminating the legislative jurisdiction of one of the regulating states. The elimination is, however, by means of state common law rather than federal constitutional law.

Taking up Professor Brilmayer's concern, a skeptic might respond that this effectively requires citizens to conform their behavior to the more restrictive state's legal regime due to uncertainty as to which state's law would be applied. There are two responses to such a critique. First, uncertainty is not inherent, but instead is the result of shortcomings in

(1932) (holding that the Host State of New Hampshire must apply Home State Vermont law). But again, this case's holding was later denied broad applicability by Nevada v. Hall, 440 U.S. 410, 421-22 (1979), in which the Court stated that the opposite result of Clapper would be permissible as a general principle.

448 See cases cited supra note 447.

449 See, e.g., SCOLES ET AL., supra note 124, at 146-47 (noting that the Supreme Court has abandoned the Clapper line of cases).

${ }^{450}$ For other suggestions that Clapper still has vitality, see Lea Brilmayer, Credit Due Judgments and Credit Due Laws: The Respective Roles of Due Process and Full Faith and Credit in the Interstate Context, 70 IOw A L. REV. 95, 107 n.74 (1984), discussing the Court's resurrection of Clapper, albeit in a limited way and with a new gloss; and Frederic L. Kirgis, Jr., The Roles of Due Process and Full Faith and Credit in Choice of Law, 62 CoRnELL L. REV. 94, 120, 122-24 (1976), arguing that when another state has an interest in applying its law that is overwhelming in comparison to the interest of the forum state, then Clapper is still authority for the proposition that the Full Faith and Credit Clause requires the nonforum state's law be applied.

${ }^{451}$ For the most important recent statements of the law of full faith and credit relevant to sorting out interstate conflicts of legislative jurisdiction, see Allstate Insurance Co. v. Hague, 449 U.S. 302, 307, 308 n.10 (1981).

452
Rosen, supra note 9. 
contemporary conflict-of-laws doctrine. If the doctrine were more determinate - and if full faith and credit were deemed to require that the same choice-of-law doctrine be applied irrespective of the forum in which an action was brought ${ }^{453}$-then this uncertainty would be eliminated and parties could know what law governed their activities. The appropriate response is to improve our choice-of-law doctrine, not to manufacture constitutional principles that purport to solve the problem through crude elimination of the Home State's legislative jurisdiction over its traveling citizens. The second response, discussed immediately below, is that having to conform one's behavior to more than one state's laws is not per se problematic.

\section{c. Embracing conflict}

The final approach is to embrace the interstate conflict. Apart from circumstances of Hard Conflict (which, in any event, probably are eliminated by the right to travel) and inconsistent regulations that unduly interfere with the national economy, having to conform one's behavior to the requirements of all interested states is not problematic. If one's activities implicate the legitimate interests of two or more states, then it makes sense to permit the interested states to regulate the activity so as to protect their legitimate interests. This is the lesson that emerges from the Court's Double Jeopardy Clause jurisprudence. And it is sensible: if more than one state's interests are affected by a particular activity, each state ought to be able to protect its interests, unless doing so problematically interferes with the constitutional federalism-based commitments of protecting interstate commerce and not interfering with interstate travel. ${ }^{454}$

453 See Laycock, supra note 380, at 310-11 (arguing that "[u]nder the Full Faith and Credit Clause, the identity of the forum is irrelevant to choice of law").

${ }^{454}$ Professor Kreimer argues that permitting the Home State to regulate its citizens' outof-state activities would be a "disincentive" to interstate travel and that "[i]n a nation whose citizenship entails a right to travel among the states . . . such disincentives to interstate travel should be minimized." Kreimer, Whoever Treasures Freedom, supra note 49, at 916. Professor Kreimer is correct that extraterritorial regulations may serve as a "disincentive" to interstate travel, but that fact alone does not answer the question of whether extraterritoriality is constitutional. As a general matter, our constitutional order is characterized by the commitment to multiple constitutional principles; constitutional doctrine virtually never reflects a decision to maximize one principle, but accommodates the numerous competing principles that are applicable in any given circumstance. So while our constitutional order undoubtedly includes a right to travel, constitutional law does not require that this right be given its maximum conceivable scope, but instead harmonizes that right with other constitutional commitments, such as the states' powers as subfederal sovereigns (which, as I have argued, includes the power to pursue efficacious regulations in respect of subject matters that themselves are not unconstitutional). The "disincentive" Professor Kreimer speaks of thus does not bespeak a constitutional deficiency, but instead is a manifestation of the fact that 


\section{CONCLUSION}

Many constitutional state policies can be skirted when citizens travel to jurisdictions that permit activities that are banned in their Home State. The United States' federal system gives states significant powers to counter such "travel-evasion." Several constitutional doctrines govern Home State extraterritorial powers. States have presumptive powers to regulate their citizens' out-of-state conduct, and extraterritorial regulation designed to protect legitimate state interests from being thwarted by citizens' out-ofstate activities satisfies due process. Such extraterritorial powers are not precluded by the Dormant Commerce Clause, so long as the regulations are not species of economic protectionism and are directed primarily to the state's own citizens. Nor is the Dormant Commerce Clause's doctrine of inconsistent regulations a significant barrier, insofar as it applies only to those subjects that by their nature must be uniform across the country to prevent undue interference with interstate commerce. Due to the right to travel, Home States may not prevent their citizens from traveling to other states. Neither the right to travel nor the Privileges and Immunities Clause, however, grant a visitor the categorical right to be subject only to the Host State's laws once she leaves her Home State. The right to travel is mute on the subject, and Host States have a substantial interest for purposes of privileges and immunities in ensuring that they do not interfere with visitors' relationships with their Home States. Finally, neither the Full Faith and Credit nor the Double Jeopardy Clauses limits Home States' powers to regulate their citizens' extraterritorial behavior, though full faith and credit doctrine as presently constituted undercuts Home States' powers to apply their laws over a particular transaction or occurrence that has been the subject of a civil lawsuit in another state.

A state's power to regulate its citizens' out-of-state activities is important to secure political heterogeneity across states. A federal system in which states did not have extraterritorial powers over their traveling citizens would systematically favor more permissive laws, undermine the states' ability to pursue paternalistic and norm-shaping goals, undercut the states' powers to protect third-party interests, and limit the extent of experimentation across subfederal polities that otherwise could occur. It is thus desirable that the Constitution is not interpreted as flatly foreclosing on extraterritorial regulation, contrary to the views of many courts and noted commentators. Subject to only a few limitations, the decision whether or not to regulate extraterritorially so as to ensure the efficacy of important 
state laws is a matter that states may decide for themselves on the merits. Even if no states elect to extraterritorially regulate their citizens, it is important that they each have the opportunity to make the choice. The very possibility of extraterritorial regulation of citizens secures rich political heterogeneity across states, and a federal regime that allows such diversity is normatively desirable under commonly held liberal premises. ${ }^{455}$

455 I would like to express my deep appreciation for Professor Kreimer's response, which appears immediately following this Article, for Professor Kreimer's scholarship has played a crucial role in shaping my views concerning extraterritoriality. Seth F. Kreimer, Lines in the Sand, supra note 10. The editors of the University of Pennsylvania Law Review have kindly allowed me a footnote to respond to his comments. These evere, though understandable, space limitations allow me to provide only a partial analysis. I hope to reply to many of Professor Kreimer's other important points at a future date.

It might be useful to start by pinpointing our precise disagreement, for Professor Kreimer is correct that there is much about which we concur. Most relevant, we agree that federalism allows room for each state to pursue different political agendas. Consider substantive policy choices that do not implicate the Constitution-such as whether or not a state should ban gambling. Because constitutional rights are not directly implicated, different states can pursue different policies in accordance with their views of what is best. For example, State $A$ can ban gambling in an effort to (let us say) paternalistically protect the would-be gambler from himself and to guard the third-party interests of his family members, whom his gambling might drive into poverty. Professor Kreimer and I part ways with respect to the extent of a state's regulatory power. Professor Kreimer believes that the Constitution imposes a secondary restriction on states in relation to policies that themselves are constitutional. For instance, even though State $A$ 's constitutional paternalistic and third-party protection goals can be readily circumvented if its citizens can travel to a state where gambling is legal and roll the dice there, Professor Kreimer believes that the Constitution flatly prevents State $A$ from taking steps to counter this side-stepping of its legitimate law. In contrast, I do not believe that there is any such general secondary restriction; though there are discrete limitations on a state's power to regulate its citizens' out-of-state activities, these constraints largely leave intact extraterritorial powers to impede the circumvention of state laws through travel. My argument is primarily positive: I claim to be describing the current state of the law. Insofar as crucial parts of the contemporary doctrine turn on normative considerations, however, my Article also examines normative factors.

Now to my brief comments. First, Professor Kreimer notes that few states have sought to extraterritorially regulate, Kreimer, Lines in the Sand, supra note 10, at 975, and that many states have vicinage requirements, $i d$. at $976 \mathrm{n} .9$, app. These interesting observations do not affect my Article's analysis. The Article's express focus is on federal constitutional limitations on extraterritorial state regulation. Supra note 33 and accompanying text. Indeed, extraterritoriality's rarity reinforces the Article's importance insofar as it seems to be attributable to most states' (mis)perceptions that the Constit ution flatly pecludes such regulation. Supra note 32. Similarly, vicinage requirements, which require that crimes be tried in the place (variously defined) where they are committed, are a product of an era during which it was believed that state legislative power did not extend beyond the state's borders. See, e.g., Pennoyer v. Neff, 95 U.S. 714, 722 (1877) ("And so it is laid down by jurists, as an elementary principle, that the laws of one State have no operation outside of its territory ....”). In any event, states can eliminate vicinage requirements, if they wish, insofar as they are state law requirements. But the extraterritorial regulations discussed in this Article likely would not require a change of vicinage requirements. Most of the regulations discussed are civil rather than criminal. Moreover, even criminal forms of the extraterritorial 
regulations discussed in this Article could satisfy state vicinage requirements. While vicinage requirements typically are met if any element of a crime occurs in the vicinage, see, e.g., United States v. Rodriguez-Moreno, 526 U.S. 275, 281 (1999) (providing the federal rule), not all states' vicinage requirements demand that "some element of the crime or preparation must occur in the county of trial," see, e.g., Price v. Superior Court, 25 P.3d 618, 634 (Cal. 2001) (noting that California's constitution does not), and vicinage requirements typically are not absolute, in any event, but may be overridden for good reasons. See, e.g., State v. Hereford, 592 N.W. 2d 247, 252 (Wis. Ct. App. 1999) (noting that "maintaining venue in the county where the crime was committed" is not "a fundamental right"). Furthermore, although no state courts apparently have confronted the question, the place where an activity's effects are felt may satisfy venue requirements if the effects are an element of the crime. Finally, even under well-established doctrine, vicinage requirements presumably could be satisfied if included as an element of the crime were some in-state activity (like the planning that their citizen's undertook) that typically accompanies the out-of-state activity that the legislature wished to regulate.

Next, although Professor Kreimer interprets many cases in importantly different ways than I do-the details of which I unfortunately cannot address here and will discuss in future scholarship - when all is said and done he appears to agree with the following conclusions to which I come in my Article. As a matter of positive law, (1) the extent of a Home State's baseline extraterritorial powers is determined by the Shutts test, which asks whether application of a state's law would be "“arbitrary"” or "“fundamentally unfair,", see Kreimer, Lines in the Sand, supra note 10, at 993 (citations omitted); (2) the Privileges and Immunities Clause of Article IV imposes limits on one state's ability to regulate noncitizens, but has been held to not impose limitations on a Home State's power to regulate its own citizens, $i d$. at 1003 \& n.121; and (3) the Privileges and Immunities Clause allows a state to distinguish between citizens and noncitizens where there is a "substantial" reason for so doing, $i d$. at 1006-07. Furthermore, Professor Kreimer does not dispute that (4) the right to travel has not been held to include a right for visitors to be subject to the same regulations as citizens if the visitor's Home State wants its peripatetic citizens to be subject to its laws while traveling, $i d$. at 1007-08; (5) nor does he dispute that the Supreme Court upheld an extraterritorial regulation over a Dormant Commerce Clause challenge in the CTS case and that, more generally, many state laws (such as product liability laws) have significant regulatory effects on out-of-state actors. CTS Corp. v. Dynamics Corp. of America, 481 U.S. 69 (1987).

Taken together, these propositions establish two things. First, as a matter of positive law, states are not flatly prohibited from regulating their citizens' out-of-state activities. Second, to what extent they have such regulatory powers turns on largely normative considerations: whether extraterritorial application would be "arbitrary" or "fundamentally unfair," and whether there is a "substantial reason" for a Host State to apply the Home State's law to a visitor in accordance with the Home State's wishes. (Indeed, several other crucial parts of Professor Kreimer's analysis also are normatively impelled rather than "legally compelled," Kreimer, Lines in the Sand, supra note 10, at 975. Consider, for example, his argument that the right to travel "becomes a hollow shell" unless it includes a visitor's right to do what residents can do, $i d$. at 1007 , and that privileges and immunities doctrine be reworked so that it limits Home States, $i d$. at 1003.)

For these reasons, my Article contains an extensive analysis of the normative considerations that attend the question of whether states enjoy the power to extraterritorially regulate their citizens. Though I will not reproduce that analysis here, I would like to make a few comments about Professor Kreimer's treatment of the Article's normative analysis. First, a reader of Professor Kreimer's Article could easily conclude that the only rationale for extraterritoriality is the "projection of perfectionist morality"-a goal that most readers presumably would not be particularly sympathetic to (more on this shortly). Kreimer, Lines in the Sand, supra note 10, at 1008; see also id. at 981 ("perfectionist morality"); id. at 986 
(referring to "Professor Rosen's regime of extraterrit orial moralism"); id. at 991-92 ("extraterritorial moralism"); id. at 1006 (same); id. at 1017 ("extraterritorial assertion of moralism"). In fact, this Article explains that the power to regulate extraterritorially is important for states to achieve far less controversial goals. Such powers are critical whenever a law seeks to protect third-party interests or to serve paternalistic goals. Moreover, extraterritorial powers help to advance structural federalism interests by allowing political diversity and experimentation across states in respect of constitutional substantive policies. Supra Parts I.C.3, II.A.4, II.B.

Although Professor Kreimer gives virtually no attention to these latter justifications for extraterritoriality, he does critique the Rawlsian argument I provide for why, contrary to what one is likely to believe at first, extraterritorial powers that allow the advancement of "perfectionist" political agendas are normatively desirable from the perspective of liberalism. I developed the core of this argument in an earlier article, see Rosen, Outer Limits, supra note 109, at 1053-1144, and in this Article I apply it to the issue of extraterritoriality, supra at Part I.C.3.b. At the outset, it is important to note that my argument does not claim to be a straightforward application of Rawls's framework, but a self-conscious reworking of it. See Rosen, Outer Limits, supra note 109, at 1108-10, 1110-24, 1124-25 (arguing that Rawls's analysis overlooks the subfederal polities; that their existence requires the adjustment of several aspects of Rawls's framework; and that liberalism as a result can achieve a greater degree of "neutrality in effect" and accommodate more types of persons than even Rawls thinks is possible). As such, I think it is misleading to describe an explicit reformulation as a "misappl[ication]" of Rawls's analytical framework, Kreimer, Lines in the Sand, supra note 10 , at 1009, particularly insofar as my analysis anticipates Professor Kreimer's astute objections, see Rosen, Outer Limits, supra note 109, at 1106-26.

Professor Kreimer's core rejoinder to my Rawlsian argument is that a person in the original position would not select a political structure in which states had extraterritorial powers, because it would be too burdensome. After all, he argues, if a state enacted a law that advanced the behavior norm of $Z$, and a person were a $Z$-opponent, that person would be forced either to abide by the norm of $Z$ or to "leave[ her] home, ... job and ... friends entirely" in the event that the state in which she lived had extraterritorial powers. Kreimer, Lines in the Sand, supra note 10, at 1013. Faced with this prospect, Professor Kreimer argues, a person in the original position would choose a political structure in which states did not have extraterritorial powers. Id.

I think that Professor Kreimer's criticism is mistaken. This can be seen best by considering what he assumes the person in the original position would be willing to sacrifice. Professor Kreimer acknowledges that there are persons who hold a good faith belief that their ability to self-actualize (in particular, their capacity to formulate a conception of the good) depends on the active involvement of some subfederal level of government. Id. at 1010; Rosen, Outer Limits, supra note 109, at 1064-71, 1090-93. Professor Kreimer also concedes that such persons (whom I have dubbed "localist plitical perfectionists," Rosen, Outer Limits, supra note 109, at 1069), might believe that among the powers their subfederal polity must have is the power to extraterritorially regulate its citizens. Kreimer, Lines in the Sand, supra note 10, at 1010. Professor Kreimer's argument thus assumes that a person in the original position, not knowing whether she represented a non-perfectionist or a "localist political perfectionist," would choose a national political structure in which she could actualize herself if she were a nonperfectionist, but not if she happened to be a political perfectionist, even though she could have chosen a political structure in which she could have been asured a place in which she could have been accommodated whether she were a perfectionist or a nonperfectionist. I submit that if one takes seriously the original position's thought experiment of attempting to construct a fair society by asking what political structure would be chosen by a person who really did not know whether she represented a perfectionist or a nonperfectionist, a person would not come to Professor Kreimer's conclusion. This is 
because the downside she would face if she in fact represented a perfectionist (absolute inability to self-actualize anywhere in this country) would be far steeper than the relocation costs she would bear if she represented a nonperfectionist who were born into a perfectionist polity that extraterritorially regulated its members. Stated differently, basic liberties (i.e., the liberty to develop a conception of the good) trump even significant costs of inconvenience (i.e., relocation costs). More generally still, a host of differences among states (e.g., jobs, marital prospects, climate, and geography) makes one state more attractive in one person's eyes than another, thereby enticing her to move. Why should the list of differences among states not include full-bodied differences in states' political communities with respect to regulations that themselves are not unconstitutional? As Tieboutian analysis suggests, diverse offerings of public goods across polities can increase utility, for people can choose to live in the polity that affords them the public goods they value. See Tiebout, supra note 258, at 416. (In any event, even if one were unconvinced by this Rawlsian argument, there remain the above-mentioned, less controversial justifications for extraterritoriality.)

Finally, I would like to say that I, like Professor Kreimer, believe that states' physical boundaries are very important. I believe, however, that careful consideration shows that they are only imperfect surrogates for demarcating where a polity's legitimate interests end. This mismatch between physical boundaries and legitimate interests has grown over time due to various technological revolutions that increase the frequency of cross-border activities and, in the process, provide citizens ever greater opportun ities to structure their activities so as to free themselves of their Home State's regulations. This is true even when those activities primarily impact their Home State's interests for all practical purposes. Though many people-state governmental officials included-think that state legislative jurisdiction is coterminous with state borders, this is a bygone, mistaken conception that erroneously deprives states of extraterritorial regulatory powers that rightfully are theirs to exercise, if they so choose. Describing the true scope of states' extraterritorial powers, and explaining the normative considerations that attend the exercise of such powers, were the tasks of this Article. 